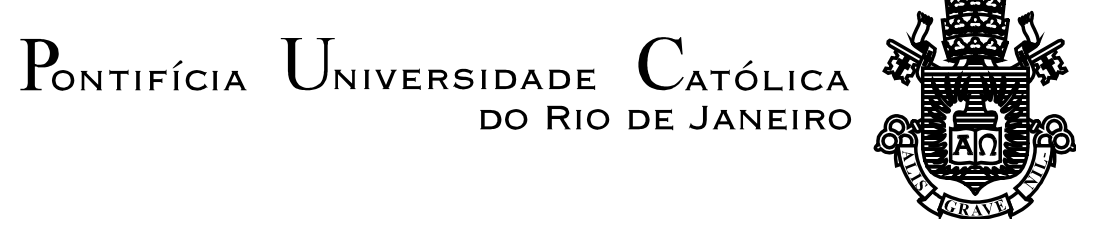

Regina Maria Orth de Aragão

\title{
Presença/ausência materna e os processos de subjetivação
}

\section{Tese de Doutorado}

\begin{abstract}
Tese apresentada como requisito parcial para obtenção do grau de Doutor pelo Programa de Pós-graduação em Psicologia do Departamento de Psicologia da PUC-Rio.
\end{abstract}

Orientadora: Profa. Claudia Amorim Garcia

Rio de Janeiro

Abril de 2016 
Pontifícia Universidade Católica $_{\text {a }}$

DO RIO DE JANEIRO

\section{Regina Maria Orth de Aragão}

\section{Presença/ausência materna e os processos de subjetivação}

Tese apresentada como requisito parcial para obtenção do grau de Doutor pelo Programa de PósGraduação em Psicologia (Psicologia Clínica) do Departamento de Psicologia do Centro de Teologia e Ciências Humanas da PUC-Rio. Aprovada pela Comissão Examinadora abaixo assinada.

Profa. Claudia Amorim Garcia

Orientadora

Departamento de Psicologia - PUC-Rio

Profa. Silvia Maria Abu Jamra Zornig

Departamento de Psicologia - PUC-Rio

Prof. Octávio Almeida de Souza

Instituto Fernandes Figueira - FIOCRUZ

Prof. Luis Cláudio Mendonça Figueiredo Departamento de Psicologia - PUC/SP

Profa. Isabel da Silva Kahn Marin Departamento de Psicologia - PUC/SP

Profa. Denise Berruezo Portinari Coordenadora Setorial de Pós-Graduação

e Pesquisa do Centro de Teologia e Ciências Humanas - PUC-Rio

Rio de Janeiro, 01 de abril de 2016. 
Todos os direitos reservados. É proibida a reprodução total ou parcial do trabalho sem autorização da universidade, da autora e da orientadora.

Regina Maria Orth de Aragão

Bacharel e Licenciada em Psicologia na Faculdade de Psicologia, Ciências e Letras, Universidade de São Paulo em 1969. "Maîtrise Psychologie Clinique" na Universidade Paris VII em 1972. Especialista em "Psychologie Pathologique" na Universidade Paris V em 1973. Título de Mestre em Psicologia Clínica na Pontifícia Universidade Católica de São Paulo em 2007. Psicanalista, membro do Círculo Psicanalítico do Rio de Janeiro.

Ficha Catalográfica

\section{Aragão, Regina Maria Orth de}

Presença/ausência materna e os processos de subjetivação /

Regina Maria Orth de Aragão; orientadora: Claudia Amorim Garcia. - 2016.

135 f. ; $30 \mathrm{~cm}$

Tese (doutorado) - Pontifícia Universidade Católica do Rio de Janeiro, Departamento de Psicologia, 2016.

Inclui bibliografia

1. Psicologia - Teses. 2. Processos de subjetivação. 3. Continuidade psíquica. 4. Ambivalência materna. 5. Ritmicidade conjunta. I. Garcia, Claudia Amorim. II. Pontifícia Universidade Católica do Rio de Janeiro. Departamento de Psicologia. III. Título. 
Ao Benjamim e ao Martim, meus netos, que muito me ensinam sobre bebês e crianças. 


\section{Agradecimentos}

À Claudia Amorim Garcia, pelos ensinamentos transmitidos ao longo desses anos de estudo, e pela atenção e disponibilidade fundamentais para a realização do trabalho.

Ao Luis Claudio Figueiredo e à Silvia Zornig, pelas indicações e sugestões durante o Exame de Qualificação, contribuindo decisivamente com suas questões para o desenvolvimento do trabalho.

Aos colegas e amigos do Programa de Pós-Graduação, pelas ricas trocas durante os anos de estudo.

Aos professores e funcionários do Programa de Pós-Graduação, que contribuíram decisivamente para a realização do trabalho.

Aos meus pacientes, crianças e adultos, por tudo o que têm me ensinado.

Aos meus amigos queridos, que suportaram minha disponibilidade reduzida nos últimos tempos, e me ajudaram a pensar profundamente nas implicações dessa empreitada.

Aos meus filhos que mantiveram sempre presente a atenção, o cuidado e o interesse pelo trabalho que eu realizava. 


\section{Resumo}

Aragão, Regina Maria Orth de; Garcia, Claudia Amorim (Orientadora). Presença/ausência materna e os processos de subjetivação. Rio de Janeiro, 2016. 135p. Tese de Doutorado - Departamento de Psicologia, Pontifícia Universidade Católica do Rio de Janeiro.

A pesquisa, que se situa no campo dos estudos sobre a constituição subjetiva, apresenta hipóteses sobre a relação entre os processos de subjetivação e as funções do objeto primordial. Como a clínica das patologias graves de crianças e adultos tem indicado a importância dos processos iniciais de subjetivação, tornou-se necessário aprofundar a compreensão de aspectos fundamentais desses processos, entre os quais a instauração da experiência interna da continuidade psíquica ocupa um lugar central. Nessa perspectiva, o estudo busca elucidar a interligação entre a alternância entre presença e a ausência materna, importante para a constituição da continuidade psíquica, com a dinâmica da ambivalência materna em relação à criança, considerando a expressão dessa ambivalência nos modos de presença e de ausência da mãe e na regulação da ritmicidade conjunta entre mãe e bebê.

\section{Palavras-chave}

Processos de subjetivação; continuidade psíquica; ambivalência materna; ritmicidade conjunta. 


\section{Résumé}

Aragão, Regina Maria Orth de; Garcia, Claudia Amorim (Orientadora). Présence/absence maternelle et les processus de subjectivation. Rio de Janeiro, 2016. 135p. Thèse de Doctorat - Departamento de Psicologia, Pontifícia Universidade Católica do Rio de Janeiro.

La recherche, qui se situe dans le champ des études sur la constitution subjective, présente des hypothèses sur la relation entre les processus de subjectivation et les fonctions de l'objet primaire. La clinique des pathologies graves de l'enfant et de l'adulte ayant indiqué l'importance des processus primaires de subjectivation, il s'est avéré nécessaire d'approfondir la comprehénsion de certains aspects fondamentaux de ces processus, parmi lesquels l'instauration de l'expérience de continuité psychique occupe une place central. Dans cette perspective, l'étude cherche à élucider la liaison entre l'alternance présence/absence maternelle, importante pour la construction de la continuité psychique, avec la dynamique de l'ambivalence maternelle à l'égard de l'enfant, considérant l'expression de cette ambivalence dans les modes de présence de la mère et de son absence, ainsi que dans la régulation de la rythmicité conjointe entre mère et bébé.

\section{Mots-clés}

Processus de subjectivation; continuité psychique; ambivalence maternelle; rythmicité conjointe. 


\section{Sumário}

1. Introdução 9

$\begin{array}{ll}\text { 2. O psiquismo nascente } & 18\end{array}$

2.1. A instauração da continuidade psíquica: entre diferenciação e separação 18

2.2. Da sensorialidade à simbolização 29

2.2.1. A sensorialidade e o psiquismo fetal 29

2.2.2. A sensorialidade e a atividade psíquica 38

3. Os processos de maternalidade e a ambivalência materna 48

3.1. Os processos de maternalidade $\quad 48$

3.2. Narcisismo materno e inclusão do bebê estranho/familiar 55

3.3. A ambivalência materna $\quad 62$

4. O ritmo e a complexidade dos jogos simbolizantes $\quad 68$

4.1. O ritmo e os processos de subjetivação $\quad 69$

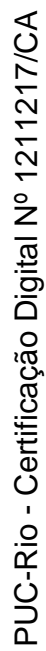

4.2. A estrutura enquadrante e a função simbolizante do objeto 82

5. Entre mãe e bebê: presença e ausência 91

5.1. Os processos arcaicos e a simbolização primária 91

5.2. A simbolização e a linguagem verbal 101

6. Considerações finais: 114

O psiquismo do bebê e os fundamentos da posição clínica 114

7. Referências bibliográficas 126 


\section{Introdução}

"Corretamente objetar-se-á que uma organização que fosse escrava do principio de prazer e negligenciasse a realidade do mundo externo não se poderia manter viva, nem mesmo pelo tempo mais breve, de maneira que não poderia ter existido de modo algum. A utilização de uma ficção como esta, contudo, justifica-se quando se considera que o bebê - desde que se inclua o cuidado que recebe da mãe - quase realiza um sistema psíquico deste tipo". (Freud, 1911/1976, p. 279) (grifos nossos).

Esta pesquisa se situa no campo dos estudos sobre a constituição psíquica. Dada a riqueza e a diversidade do panorama atual dos estudos sobre o psiquismo nascente, com novos dados advindos tanto da psicanálise como das disciplinas próximas, tais como neurociências, psicologia do desenvolvimento e estudos fetais, foi preciso fazer um recorte necessariamente arbitrário, privilegiando alguns ângulos de incidência sobre a complexidade do campo, considerando ainda que todos eles se inter-relacionam estreitamente e são de certo modo interdependentes uns dos outros. Como em tudo o que diz respeito ao psiquismo nas fases iniciais, as fronteiras são tênues e movediças, entre o sujeito e o objeto, entre as funções que estão em pleno desenvolvimento, que se entrelaçam e interferem mutuamente, entre o ambiente e o indivíduo. Neste sentido, antes de mais nada, quando adentramos esse campo do originário, é necessário lembrar a ressalva colocada por Piera Aulagnier (1975), segundo a qual é somente em razão de uma obrigação metodológica que se separa, de modo arbitrário, o espaço psíquico do bebê do espaço psíquico da mãe, já que são na verdade indissociáveis nesses tempos iniciais da vida psíquica.

As concepções psicanalíticas nas últimas décadas têm se voltado para os estudos relativos à constituição do sujeito, e ao ressaltar a importância das relações intersubjetivas na constituição do psiquismo, apontam para uma articulação entre a dimensão pulsional e a qualidade das relações entre sujeito e objeto primordial no início da vida. Por outro lado, o pensamento psicanalítico contemporâneo tem sido confrontado com a dificuldade de tratar os casos graves e 
os sofrimentos narcísico-identitários, o que trouxe o objeto materno para o centro da cena analítica pós-freudiana. Assim, tanto o estudo das condições das experiências subjetivas precoces, quanto a necessidade de compreender as falhas constitutivas iniciais, obrigam a levar em conta as respostas e reações dos objetos primordiais. É nessa perspectiva que o objeto materno tem sido estudado em torno da qualidade de sua presença, para além de se descrever os efeitos de sua ausência. O papel central dessa presença nas construções primárias tem sido evidenciado pelos distúrbios do narcisismo e da simbolização, associados à falhas do investimento materno.

Freud sustentou o primado do paterno e do pensamento sobre o sensorial e o materno, e explorou muito pouco a importância do período anterior ao Édipo na construção do sujeito. Apresentou e desenvolveu o papel central dos conflitos internos, como o organizador dos movimentos psíquicos e da neurose. Ainda na segunda metade do século XX foi a escola inglesa que inicialmente colocou a ênfase sobre a função primária do objeto materno e sobre os processos arcaicos. Mas foram as formas de sofrimento psíquico contemporâneo mais recentemente que levaram o pensamento psicanalítico a voltar sua atenção para o papel do objeto, da influência do ambiente, e do peso da realidade externa no desenvolvimento psíquico, aí consideradas as condições sócio-históricas e culturais que afetam os processos de subjetivação.

Assim, o materno aparece no centro da cena, com seu cortejo de excessos e de faltas. A potência do investimento narcísico, o cuidado tomado com essa parte de si que é a criança, biológica ou não, criam a paixão amorosa materna. Esta permeabilidade ao outro que favorece os cuidados adequados e o prazer compartilhado coloca em risco o Eu do adulto que nele se engaja. Essa fusão sustentadora inicial necessária para a constituição do sujeito pode pecar pelo excesso, pode se tornar intrusiva e invasiva, prejudicando a construção do self, que fica fragmentado ou se torna falso. Ou, no sentido oposto, serão a falta, a carência e a ausência de resposta à necessidade do sujeito que deixarão uma marca indelével, uma amputação de si. Dessa maneira, o olhar sobre o funcionamento psíquico dos pais tomou a dianteira sobre a dinâmica interna do sujeito no panorama psicanalítico atual. 
A preocupação com as questões relativas à importância do objeto primário nos primórdios da constituição psíquica já havia norteado nossa pesquisa de mestrado (Aragão, 2007). O presente estudo nasceu, portanto da necessidade de aprofundar questões trabalhadas na dissertação intitulada: "A construção do espaço psíquico materno e seus efeitos sobre o psiquismo nascente do bebê", e propõe tratar de novos questionamentos advindos tanto da própria clínica como de reflexões surgidas a partir de estudos teóricos no campo dos processos iniciais da subjetivação, explorando mais detalhadamente algumas interrogações que ficaram em aberto na pesquisa anterior.

Nesta perspectiva, a questão que acompanha esse percurso poderia ser resumida da seguinte maneira: como se transmitem, entre mãe e bebê, os conteúdos inconscientes que farão marca no psiquismo nascente do infans? E, em decorrência, como é possível pensar a transformação do psiquismo nascente, quando si e o outro estão inicialmente confundidos, para chegar ao aparelho psíquico propriamente dito, uma composição que se tornará capaz, pouco a pouco, de dar forma e sentido, de representar e de brincar com as representações? Mais especificamente, qual o papel da alternância presença/ausência materna neste processo?

A hipótese central que essa pesquisa se propõe elucidar, portanto é a que interligaria a alternância presença/ausência materna, fator descrito por diferentes autores como determinante para a continuidade psíquica, com a dinâmica da ambivalência materna em relação à criança, considerando a expressão dessa ambivalência nos modos de presença da mãe e na regulação da ritmicidade conjunta entre mãe e bebê. A ambivalência materna é herdeira das relações da mãe com seus primeiros objetos, em especial herdeira da ambivalência materna em relação à sua própria mãe. A elaboração dessa ambivalência infiltrará o modo de presença da mãe com sua criança, e envolverá a maneira como o objeto se apresentará ao sujeito facilitando ou dificultando seus processos primários de simbolização, assim como a maneira como ele aceita, ou não, deixar lugar no psiquismo da criança para a inscrição de objetos substitutos.

Quando se considera a alternância presença/ausência do objeto como um dos fatores centrais para o estabelecimento da continuidade psíquica, relacionado com o eixo continuidade/descontinuidade, fica pressuposto que basta a alternância 
para o processo ocorrer. Propomos refletir para além dessa constatação, sobre as condições em que se dá essa alternância. Nesse sentido, importa considerar que a alternância presença/ausência se expressa em relação a uma temporalidade, de um lado, e, por outro lado, é marcada pela "qualidade" da presença e também da ausência, isto é, do modo pelo qual o objeto se faz presente, e do modo pelo qual o objeto se faz ausente. Nesse último caso, o estar ausente terá diferentes consequiências segundo a capacidade, ou não, do objeto materno de manter viva a representação do bebê no interior de si. Em outras palavras, como se apresenta no modo de estar com o bebê, ou no modo de não estar com ele, a oscilação inevitável dos sentimentos maternos e quais efeitos tal oscilação vem a ter sobre os processos de subjetivação?

O encontro com o outro, fundador para o bebê, pressupõe a reciprocidade, para a qual sabemos que o bebê está apto ao nascer, o que confirmam os estudos sobre as competências do recém-nascido. Ao mesmo tempo, o encontro do bebê com o outro, adulto, é marcado pela dissimetria. E é nesse espaço entre a reciprocidade e a dissimetria que vai se construir o psiquismo (Aragão, 2007). Para que tal sistema se instale, é preciso que exista uma disponibilidade bilateral e recíproca, que pressupõe, do lado do infans, um estado somático adequado, e a consideração das variações de seu ritmo de vigilância e retraimento (Ciccone, 1997). Do lado do adulto, a disponibilidade vai permitir que os sinais emitidos pela criança sejam recebidos, decodificados, traduzidos e interpretados. Assim, condição básica para a instauração do psiquismo é a chamada acessibilidade materna, que permitirá a instalação de sistemas interativos precoces, os quais exigem a disponibilidade relacional bilateral e recíproca. Essa acessibilidade materna, receptora dos sinais do bebê, decodificadora e tradutora, permitirá que eles lhes sejam devolvidos depois de um trabalho de interpretação, necessária e criativamente violenta, como indica Piera Aulagnier (1975). Uma parte de nosso estudo retomará assim a discussão já desenvolvida anteriormente (Aragão, 2011) sobre como se constrói, na mulher, essa condição de acessibilidade materna, necessária para oferecer ao bebê o continente para seu advento como sujeito psíquico separado, destacado do amálgama psíquico inicial.

A constituição do aparelho psíquico parece atender a uma exigência posta ao bebê de lidar com a descontinuidade da vida após o nascimento, de reencontrar 
sua sustentação, seu contato com o objeto a partir do qual se constituirá toda a gama de relações entre ambos. Entre a vida antes e depois do nascimento, colocase a exigência de um trabalho para fazer face às mudanças na experiência de continuidade experimentada no útero materno. Mesmo sabendo que o corte entre a vida intra-uterina e a vida aérea não é tão absoluto, já que ao nascer o bebê traz consigo memórias que lhe permitem um reconhecimento mínimo do ambiente materno, há mudanças significativas com as quais ele tem de se haver. O trabalho psíquico a ser desenvolvido pelo bebê é aquele que lhe permitirá fazer face à descontinuidade da relação com o objeto externo, por meio dos processos de simbolização, que se relacionam com a conquista da capacidade de pensar o objeto em sua ausência.

Esses processos iniciais de simbolização se apóiam sobre a sincronia das primeiras relações, e vários dos trabalhos que iremos apresentar buscam evidenciar as diferentes modalidades e facetas desse encontro entre a mãe e seu bebê. Em especial ressaltam-se os aspectos rítmicos da comunicação entre eles, compondo uma ritmicidade conjunta que, quando harmoniosa, permite à criança restabelecer sua continuidade e gradualmente internalizá-la, podendo assim abrir mão da presença efetiva do objeto primário. Lembramos que a interação é primeira e primordial, porque a criança só tem acesso ao mundo dos signos, das significações e dos símbolos no interior de sua relação ao outro. Nos tempos primeiros, ela necessita de seu corpo e do trabalho psíquico do outro. Nessa perspectiva, a importância da sensorialidade no campo da construção do sujeito está hoje em dia absolutamente reconhecida, e os trabalhos atuais sobre o desenvolvimento precoce do bebê colocam o corpo e a sensorialidade na página de frente das modelizações teórico-clínicas.

Então, a partir da clínica das relações iniciais e em especial da clínica das patologias graves incidindo sobre os processos de subjetivação, apresenta-se a necessidade de aprofundar a compreensão de aspectos fundamentais desses processos, um deles referindo-se à instauração da experiência interna da continuidade psíquica. As falhas nas relações iniciais que levam eventualmente a patologias graves e precoces, evidenciam a importância da instauração dos processos de diferenciação e de separação, indissociáveis da experiência de permanência do objeto e de continuidade psíquica. Trata-se, para o infans, de 
poder "perceber" "eu sou..." em qualquer circunstância, em diferentes momentos da vida, só ou com a mãe, para poder se sentir existir em permanência.

D.W. Winnicott (1958) descreve três estágios do desenvolvimento emocional partindo do «eu » para passar ao «eu sou»e chegar ao «eu estou só ». $\mathrm{O}$ acesso ao «eu » indicaria uma primeira unidade, a integração inicial e a possibilidade de reconhecer o mundo interno e o mundo externo como separados. Quando, hipoteticamente, o bebê pode «enunciar »: «eu sou », isso significaria que ele se percebe vivo mas vulnerável, tendo intensa necessidade de proteção de seu ambiente. No estágio do «eu estou só » o bebê pode reconhecer a continuidade da existência de sua mãe, contanto que ela se mostre confiável. Esta condição pode surgir durante o segundo semestre de vida do bebê, mas Winnicott enfatiza que a mãe deve continuar a se mostrar confiável para consolidar esta capacidade. Assim, a capacidade de estar só depende da maneira pela qual a criança foi sustentada - do holding materno - durante os dois primeiros anos de vida, tempo necessário para que ele possa internalizar verdadeiramente essa função materna (Abram, 2001).

Tendo necessariamente experimentado sua capacidade de estar só em presença da mãe, o bebê pode doravante estar só, pois ele guardou bem no interior de si a mãe ausente, mas transformada dentro dele em uma representação que faz parte de seu mundo psíquico, com a qual ele pode então contar. Esta passagem implica a possibilidade para o bebê de ter feito o luto do objeto primário, luto que só ocorre se, paradoxalmente, a presença interna do objeto perdido é assegurada durante sua ausência. Em outras palavras, para que haja presença interna é necessário que tenha havido ausência real; como disse S. Freud (1925) em primeiro lugar, o objeto encontrado sendo justamente o objeto reencontrado.

Resumindo, a pesquisa apresenta algumas hipóteses sobre a relação entre os processos de subjetivação na interface com as funções do objeto primário, sob a forma de um estudo teórico que busca articular as questões suscitadas pela clínica, com os saberes que têm avançado compreensões diversas em relação à problemática da constituição do psiquismo, em sua grande complexidade. Fazemos a ressalva de que, tratando-se de processos muito iniciais, anteriores à constituição do aparelho de linguagem, as hipóteses desenhadas pelos diferentes autores são todas elas baseadas em construtos a posteriori, mesmo quando 
resultantes de procedimentos de observação das interações iniciais entre o bebê e seu parceiro. Além disso, há o risco de se compreender essas construções teóricas a respeito das etapas iniciais dos processos de subjetivação como tomadas numa temporalidade linear, que simplificaria de modo deformado a complexidade dos processos que estão em jogo nos tempos do bebê. Em outras palavras, uma suposição básica a ser sempre lembrada é a de sustentar que os processos psíquicos arcaicos e constitutivos do psiquismo continuam inscritos, presentes e eventualmente atuantes na vida de cada sujeito. É, aliás por esse motivo que a clínica tratando de falhas graves na subjetivação tem se beneficiado das compreensões advindas desses estudos sobre a subjetivação inicial.

Para o desenvolvimento do estudo foi feito um levantamento da literatura utilizando especialmente a produção teórica de psicanalistas mais diretamente preocupados com as questões acima, seja em razão de suas próprias práticas clínicas, seja pelo interesse metapsicológico em torno da origem do psiquismo, como foram delineadas no pensamento freudiano e como se desenvolveram nas últimas décadas.

No primeiro capítulo, sobre o psiquismo nascente, serão inicialmente tratados os temas da diferenciação e da separação, que assinalam a primeira distinção fundamental entre o Eu e o outro, condição primeira para a subjetivação. Os processos de diferenciação e de separação devem ser articulados com a progressiva conquista da capacidade de simbolização pela criança, em estreita interdependência de suas trocas com o objeto. Em seguida, para um melhor entendimento das condições propiciadoras da diferenciação, voltaremos o foco para a sensorialidade no psiquismo fetal, para depois apresentar algumas hipóteses básicas sobre as ligações entre a sensorialidade do bebê após o nascimento e o desabrochar de sua atividade psíquica.

No segundo capítulo, a etapa seguinte da pesquisa retoma e atualiza os estudos sobre os processos de maternalidade e o lugar psíquico que o bebê vem a ocupar para a mãe, antes e depois do nascimento. Essa retomada se justifica pela necessidade de compreender as raízes da ambivalência materna, de modo a estudar seus efeitos na relação da mãe com a criança, em particular nos seus modos de presença junto ao bebê, e nos condicionantes de sua ausência. 
No terceiro capítulo apresentaremos alguns estudos e hipóteses correlacionando o ritmo com as estruturações do psiquismo, em particular no que diz respeito à conquista de uma identidade singular pelo bebê a partir de sua experiência rítmica com a mãe ou com quem faça sua função, oferecendo-lhe um suporte sensorial que se inscreverá no corpo e no psiquismo como a marca de uma modalidade fundamental de troca e de encontro com o outro. Nesse sentido, será destacado o estabelecimento de uma ritmicidade conjunta entre mãe e bebê, considerada como um dos caminhos fundamentais para que o bebê tenha acesso à inter-subjetividade. Supomos que o ritmo é que faz ligação entre as várias 'áreas' da transmodalidade do bebê, favorecendo a progressiva integração das várias experiências sensoriais que se apresentam dispersas e não integradas no corpo do bebê.

No seguimento desse mesmo capítulo, foram destacadas as noções de estrutura enquadrante (Green, 1993) e função simbolizante do objeto (Roussillon, 2010) que serão apresentadas e discutidas com o intuito de aprofundar a compreensão das funções essenciais do objeto materno para facilitar, ou não, os processos de subjetivação e de simbolização da criança.

No capítulo seguinte discutiremos os processos de simbolização em presença e em ausência do objeto. A fim de nos dedicarmos mais de perto ao campo da simbolização, serão lembrados construtos teóricos que dizem respeito aos processos arcaicos, reunindo algumas noções que têm em comum a consideração do corpo como base dos sistemas de simbolização precoce, e situam esses sistemas claramente no campo das primeiras interações entre o sujeito e o objeto. Aqui discutiremos os primeiros níveis de simbolização constituindo os significantes elementares, os quais não se referem à ausência do objeto libidinal, mas, ao contrário, se apóiam sobre a garantia de sua presença.

Chegaremos à simbolização secundária, e às condições de advento da linguagem verbal, tendo como referência a ligação com o objeto primordial, na condição de sua ausência e da representação de sua ausência. Nesse tópico serão tratados os efeitos da ambivalência na relação da mãe com sua criança, e como essa ambivalência pode interferir sobre os movimentos de ligação e desligamento, produzindo as alternâncias presença/ausência, alternâncias que exigem da criança o trabalho de simbolização. 
E nas considerações finais questionamos de que maneira as bases do cuidado psíquico podem ser entendidas a partir das contribuições sobre o conhecimento do bebê nas últimas décadas, considerando que esse conhecimento sobre os processos iniciais de subjetivação oferece elementos para compreender o sofrimento psíquico em qualquer momento da vida. A clínica com crianças e em especial a clínica com bebês, como também a clínica da psicose e dos estadoslimite, nas quais os aspectos narcísicos e identitários são predominantes, têm levado a mudanças das teorias sobre o cuidado psíquico, que passam a enfatizar os processos de continência e o campo da intersubjetividade como o lugar da análise. Essas modificações tornam-se novas balizadoras do enquadre clínico, a posição clínica subjetiva sustentando-se sobre um enquadre interno e sobre o trabalho do pensar, do qual a palavra não é o único representante. Pretende-se também fazer a ligação entre a posição subjetiva do clínico, vista sob o ângulo da "parentalidade psíquica", e a necessidade de acolher e tratar os aspectos infantis e arcaicos em si e no outro, aqueles que são capazes de provocar as experiências mais perturbadoras e mais desestabilizadoras. 


\section{O psiquismo nascente}

O nascimento do psiquismo e o nascimento do objeto são indissociáveis. O psiquismo se constitui ao mesmo tempo em que o objeto ganha, paulatinamente, o estatuto de existência para o sujeito.

\section{1}

\section{A instauração da continuidade psíquica: entre diferenciação e separação}

Depois da descontinuidade imposta pelo nascimento, um bebê deve construir pouco a pouco, sobre a base de suas relações primordiais, sua continuidade psíquica que corresponde ao "sentimento contínuo de existir", segundo D.D. Winnicott (1960). Com efeito, o bebê deve passar muito rapidamente da continuidade intra-uterina, mesmo não sendo ela absoluta, para a descontinuidade dos ritmos que se apresentam após o nascimento - ritmos biológicos, alimentares, alternância dia/noite. No plano psíquico será o acesso ao processo de simbolização e à capacidade de poder pensar o objeto em sua ausência que progressivamente aplacará a descontinuidade primeira da relação com o objeto externo. A hipótese proposta por B. Golse (1990) é a de que o aparelho psíquico que se constitui pouco a pouco tem como função principal a de obturar as descontinuidades do vínculo com a realidade externa por meio da instalação progressiva de uma continuidade interna.

Supõe-se que a continuidade do psiquismo funda-se sobre um ritmo que envolve a alternância entre presença/ausência, sobre um fundo de permanência do objeto. A simbolização constrói representações, objetos internos, que vão povoar o mundo vivo no interior da criança. A simbolização nasce da ausência, mas o papel do objeto em sua presença é fundamental para que o processo de simbolização possa se iniciar. Para M. Boubli (1997) a ausência só pode ser suportável e simbolígena se tiver havido suficiente presença, e presença confiável, completaríamos. A continuidade psíquica passa necessariamente pela 
permanência do objeto internalizado. Duas questões se colocam, em conseqüência: como essa permanência se constitui, considerando as interações entre mãe e criança? E, será a permanência suficiente para a determinação da continuidade psíquica?

A instauração da continuidade psíquica deve ser compreendida à luz dos processos distintos de diferenciação e de separação. Segundo Roussillon (2010) a complexa tarefa do bebê antes da constituição da linguagem verbal é a de ligar-se ao objeto e ao mesmo tempo diferenciar-se dele. A diferenciação é um prelúdio à separação, sem ela a separação não opera a não ser traumaticamente.

Sabemos que a separação entre a mãe e a criança pequena pode constituir um traumatismo patogênico correspondente à experiência do abandono, seja ele real e/ou psíquico, mas ela pode também representar um traumatismo estruturante, suscitando um processo de luto, necessário para a estruturação psíquica (Golse, 2005a). Essas duas separações se distinguem profundamente pelo fato de que uma intervém antes e a outra após a integração da vivência da intersubjetividade que acompanha a experiência do sentimento contínuo de existir. J.M. Quinodoz (1991) propõe distinguir "angústias de diferenciação" e "angústias de separação", segundo sejam angústias ligadas ao processo de diferenciação intersubjetivo ou angústias aparecendo depois da instalação da inter-subjetividade primária. No caso da separação, que pressupõe uma relação entre duas pessoas distintas, a ausência da pessoa investida toca o indivíduo em seus afetos, mas não causa risco à estrutura psíquica de seu Eu, segundo o autor. Nessas condições, em caso de perda, há a dor psíquica ligada ao trabalho de luto, mas a perda do objeto não leva a uma perda do Eu.

Porém, "separar-se" pode ter outra significação, quando ainda não há diferenciação e a ausência da pessoa importante desperta a angústia produzida pela percepção de que o objeto é distinto do Eu. Como observava Freud, (1930) no início da vida o bebê ainda não diferencia seu Eu do mundo externo, ele só vai aprender a fazê-lo pouco a pouco. Nesse caso a separação envolve uma ameaça para a integridade do $\mathrm{Eu}$, pois ainda não estão suficientemente diferenciadas as partes do objeto e o próprio Eu. A angústia aparece então porque a separação é vivida como uma perda do próprio Eu, "que parte também com o objeto, a fím de continuar a fazer um com ele" (Quinodoz, 1991, p. 40). 
Separar-se ganha então duas significações bem diferentes, em psicanálise, de acordo com o nível no qual a separação é vivida pelo indivíduo: a separação pode ser vivida no contexto de uma relação na qual uma das pessoas deixa a outra, com as reações afetivas específicas que a acompanham, ou então a separação pode ser vivida como uma perda de uma parte do Eu provocada pelo sentimento de ter perdido o objeto...Para expressar esse processo no qual o $\mathrm{Eu}$, durante o desenvolvimento infantil, tende a se tornar distinto do objeto, deveríamos, a meu ver, falar de "se diferenciar" ou de "diferenciação" (QUINODOZ, loc.cit).

Assim, quando se trata desse tempo inicial do bebê, ainda mergulhado num mundo de objetos-sensações (Konicheckis, 2013), seria preferível tratar da problemática dos primeiros laços em termos de continuidade e descontinuidade de existir, ao invés de pensar em termos de separação. O desafio essencial para o bebê nesse período é o de criar, de se criar, um sentimento de continuidade de existir apesar das inevitáveis experiências de descontinuidade que ele experimenta após o nascimento. Segundo Konicheckis as "experiências de continuidade e de descontinuidade esculpem a identidade pessoal" (Konicheckis, 2013, p. 64), e ele propõe que os fundamentos narcísicos da pessoa se formam a partir dessas primeiras experiências do sentimento contínuo de existir.

O conceito de preocupação materna primária de Winnicott (1956) descreve um estado de adaptação da mãe às mudanças de sua criança, com a qual ela se identifica e ao qual ela oferece um sentimento de continuidade de existir, afastando as ameaças a esse sentimento. Dessa forma, o bebê experimenta a continuidade através da experiência psíquica do outro e é por esse motivo que as descontinuidades com esse outro podem ser vividas como rupturas em sua própria pessoa. A mãe, durante esse estágio, modula sua retirada, seu afastamento, de tal maneira a permitir que a criança possa aluciná-la e pensá-la durante sua ausência, que não deve ultrapassar o limite suportado pelo bebê. Ela não invade o universo psíquico da criança, para permitir-lhe, justamente, iniciar a elaboração da imagem dela própria. Porém, a mãe não é somente objeto do bebê, mas é também uma outra, que por sua alteridade, sua sexualidade, impõe uma forma de descontinuidade. (Konicheckis, 2013). E pouco a pouco ela deve propor ao bebê a tarefa da desilusão, forma de separação entre o subjetivamente criado e o objetivamente percebido, como uma primeira prova de realidade. A pergunta que decorre aqui é: o que acontece quando esse processo de desilusão, necessário, que inicia a diferenciação entre o subjetivo e o objetivo, não se passa em boas 
condições? Trata-se de uma ameaça de ordem vital, eventualmente produzindo formas graves de depressão do bebê, que pode se sentir cortado dos laços que o ligam à existência. O bebê pode aqui se agarrar a elementos sensoriais, que mantêm a ilusão do contato com os objetos externos. Outra alternativa é o desenvolvimento de uma agitação incessante, como se essa agitação e movimentação mantivessem vivo o sentimento de continuidade de existir. Ambos os mecanismos, como outros que podem ser adotados pelo bebê, indicam a gravidade do risco psíquico envolvido nessa transação entre o bebê e seu objeto primordial.

B. Golse (2001) propõe distinguir três planos nesses processos iniciais de conquista do sentimento contínuo de existir, lembrando, no entanto, que não devem ser considerados segundo uma superposição cronológica linear. Segundo o autor, esses diferentes planos se superpõem e se entrecruzam, em movimentos mútuos e permanentes que remetem às dialéticas dos efeitos do a posteriori (Golse, 2001). São eles os registros dos envelopes, dos vínculos e das relações.

O registro dos envelopes, segundo Golse (2001), se situa antes da diferenciação entre o $\mathrm{Eu}$ e o objeto, e se refere a uma vivência e a um funcionamento monádico, ou mesmo autárquico. Aqui estão em jogo as angústias arcaicas, que receberam diferentes denominações segundo os autores, tais como angústia de esvaziamento, de implosão, angústias inomináveis, angústias de queda sem fim, agonias primitivas. Tais angústias arcaicas se relacionam com a constituição do narcisismo primário e se expressam muitas vezes durante as análises de crianças autistas ou com graves psicoses infantis. A instauração satisfatória desses envelopes, que passa necessariamente pelas funções do objeto primordial, permite um início de elaboração psíquica necessária e concomitante com a constituição dos primeiros vínculos entre sujeito e objeto.

$\mathrm{O}$ registro dos vínculos primitivos, que se estabelecem inicialmente no campo do funcionamento diádico, remetem aos processos de diferenciação propriamente ditos, permitindo a saída da fusão e da simbiose. Percalços nesse campo suscitariam as angústias de diferenciação e de amputação, relacionadas ainda aos restos da indiferenciação sujeito/objeto e às modalidades de ligação adesiva. 
O registro das relações, quando não se trata mais de diferenciação, mas sim de separação entre o sujeito e o objeto, remete ao registro da triangulação e do terceiro. Dificuldades nesse campo conduzem às angústias de perda de objeto, que se encontram na base das problemáticas depressivas em suas várias manifestações.

O movimento que se desenvolve entre esses três planos, dos envelopes até a instauração de relações, pode ser compreendido como promovendo o acesso à intersubjetividade. Golse (2001) propõe uma equivalência segundo a qual a separação estaria para a diferenciação como o auto-erotismo (que pressupõe sempre uma representação do objeto) estaria para a auto-sensualidade (Tustin, 1986). Esses três níveis descritos pelo autor, dos envelopes, dos vínculos primários e das relações, mostram a complexidade da dinâmica da separação, com seu efeito estruturante e necessário, porém comportando o risco de consequências traumáticas, dependendo das condições em que ela se dá e dos vários elementos que a compõem.

$\mathrm{O}$ autor associa o registro de constituição dos envelopes com a problemática da linguagem, que aponta para o paradoxo que a sustenta, pois ao mesmo tempo a linguagem pressupõe a admissão da separação e opera como modo de ligação com o outro. O registro da constituição dos vínculos primitivos liga-se à segunda problemática, do objeto maleável, conceito proposto por M. Milner (1977) que diz respeito à condição de 'separabilidade' do objeto. Para que se dê a diferenciação entre sujeito e objeto, uma parte do trabalho é do bebê, mas outra, fundamental, é do próprio objeto, que deve permitir ao sujeito viver alternâncias satisfatórias de aproximação e de distanciamento, oferecendo-se a ele como separável e maleável. A contribuição mais importante de M. Milner com o objeto maleável é a de fazer ressaltar a participação do objeto no estabelecimento desse gradiente de diferenciação eu/não-eu.

Milner (1977) lembra que o objeto maleável, além de participar do sistema de para-excitação, como uma substância de interposição por meio da qual as impressões são transmitidas aos sentidos, é um objeto que aceita receber marcas em sua superfície, que dão ao sujeito a ilusão de uma fusão com o objeto. Porém, essa marca é transitória, pois o objeto é capaz de auto-restauração, voltando ao estado anterior. Assim, a criança pode deixar sua marca na mãe sem medo de tê-la 
alterado ou estragado, livrando-se assim de um temor depressivo quanto ao objeto.

A distância e a diferença - Ainda segundo Golse (2001) simplesmente opondo presença e ausência, a metapsicologia psicanalítica instaura uma simplificação estreita, que não descreve a complexidade dos processos em jogo na diferenciação/separação. A ausência e a presença são dois termos inseparáveis, cada um sendo "a sombra irrefutável do outro" (Golse, 2001, p. 372). Se, na classificação proposta por Golse, a temática dos envelopes diz respeito à questão da continência, e a das relações refere-se principalmente às separações, a temática da diferenciação diria respeito, segundo ele, à questão da distância, da diferença.

O bebê, através de suas várias capacidades de transmodalidade perceptiva, (Stern, 1989) é capaz de decodificar múltiplas correspondências sensoriais, e, a partir delas, extrair invariáveis baseado nas suas diferentes experiências sensoriais e interativas. Ele forja pouco à pouco, vivendo seus sucessivos encontros interativos, uma espécie de média das características relacionais do adulto, ou dos adultos, com os quais ele interage. Essa suposição é desenvolvida nos conceitos de "representação de interações generalizadas", de D. Stern (1993) ou "modelos internos operantes" de I. Bretherton (1990) Trata-se de uma 'média' fictícia, resultante de todas as experiências vividas pela criança com o adulto de referência, uma construção intrapsíquica que o bebê vai compondo de seu objeto interno. A cada novo encontro, o bebê compararia a experiência atual com essa 'imagem média' do adulto inscrita em seu psiquismo, imagem em permanente evolução pois ela se modifica a cada novo encontro. Numa construção fictícia, poderíamos supor que essa comparação vai levar a criança, a se perguntar: 'minha mãe está como sempre é?' Ou, se ela está diferente, 'porque ela não está como sempre?' 'Por que ou por causa de quem?' A diferença pode ser um desafio construtivo para o próprio pensamento do bebê, mas pode se tornar traumática quando a distância é muito grande entre a representação interna e a apresentação atual do objeto. Todo o desafio do objeto primário é então o de se apresentar para o bebê em sua permanência, mas também levemente diferente do que é habitualmente, para permitir a criação de uma interrogação, causada pela surpresa da mudança. A surpresa deve ser modulada para não causar um choque traumático (Marcelli, 2000/2006) e ser assim o estímulo para o processo de pensamento da 
criança. A mudança na mãe introduz também a questão do "outro do objeto" (Green, 1984), que é o precursor do terceiro. Golse (2001) sugere que cada vez que o bebê experimenta sua mãe diferente do que ela é habitualmente, ele busca incriminar um terceiro para evitar pensar que é ele mesmo o responsável por esse afastamento ou por essa falha materna, tal como descrito por Green no "Complexo da mãe morta" (1988). Dessa forma se delineia o lugar do futuro terceiro, a cada vez que o bebê se refere a um pólo que não seja nem ele nem a mãe. O terceiro se constrói então no interior da própria interação, pela experiência de uma diferença entre a mãe do momento e a mãe como ela sempre foi.

Esse é o processo que se dá entre diferenciação e separação, um caminho marcado pelas interações, com suas imperfeições, aproximações, pequenas desilusões provocando a criança a construir sua própria teoria da mãe e progressivamente, mais e mais, percebendo-a como um "outro-sujeito", distinto dela, de quem ela se diferencia nesse mesmo processo.

Durante conferência em 2010 em Paris, (site Psynem Necker, 2010) René Roussillon rediscute a noção winnicotianna de "sobrevivência do objeto", situada na relação precoce entre mãe e bebê. Roussillon vai propor uma extensão da questão, desenvolvendo pontos que dizem respeito não só à sobrevivência do objeto, mas também à sua descoberta como outro-sujeito. Abrindo perspectivas clínicas que vão além do tempo inicial da infância, ele indica que os processos psíquicos em jogo persistem ao longo da vida, e se manifestam especialmente na adolescência, com todos os remanejamentos identitários envolvidos nesse período, como também nas chamadas problemáticas 'narcisico-identitárias'.

A conferência se desenvolve tomando como tema o campo do arcaico e do identitário, para discutir os fundamentos da distinção fundadora entre Eu e nãoEu, portanto o processo de diferenciação. Segundo Roussillon, trata-se de experiências subjetivas que se dão antes do Eu organizar uma historicidade, uma concepção do tempo. São as experiências vividas nos tempos muito iniciais, com a mãe, e que ficam registradas para sempre, segundo a concepção freudiana de que as experiências iniciais, antes da linguagem verbal, deixam marcas indeléveis no psiquismo humano (Freud, 1937).

Roussillon (2010) retoma a proposição freudiana sobre a construção do objeto. Para Freud, (1895) o objeto é percebido, quando presente, e alucinado, 
quando ausente. Nesse modelo, a simbolização repousaria somente sobre a ausência, e é aqui que se situa a grande mudança proposta por Winnicott, com seu 'objeto encontrado/criado'. A questão torna-se então muito mais complexa, compondo um termo da metapsicologia da dialética presença/ausência, que leva a considerar "o que está presente na ausência, o que está ausente na presença" (Roussillon, 2010). Quando há coincidência da percepção e da alucinação, que então não são excludentes, funda-se o nascimento do objeto, e abre-se o campo da simbolização. Aqui, coincidem um elemento perceptivo e um elemento alucinado, é o objeto ‘encontrado/ criado', de Winnicott (1951).

Prosseguindo em sua argumentação, Roussillon discute a questão da criatividade e da destrutividade em Winnicott. A concepção freudiana, (Freud, 1915) segundo a qual o reconhecimento do objeto nasce do ódio, não é aceita por Winnicott (1950-1955), que propõe outra compreensão, segundo a qual o que produz a capacidade de entrar em contato com a realidade não é o ódio ao objeto, não é a destrutividade, mas é o fato do objeto sobreviver à destrutividade. É sua sobrevivência que leva à descoberta de que o objeto é um outro.

No tempo inicial o bebê alucina o seio, e a mãe aparece e lhe apresenta o seio no tempo e no espaço em que o bebê pode criá-lo, é o tempo da adaptação da mãe ao seu bebê, o período da 'preocupação materna primária'. (Winnicott, 1956). O bebê, nesse momento, transforma a alucinação em percepção/criação, que o leva à ilusão de auto-satisfação, no campo do narcisismo primário. Aqui, a mãe se faz apagar, para o bebê a satisfação decorre de sua própria criação. Essa adaptação materna é hoje vista com nuances, e as observações das díades mãe-bebê permitem bem ver que se trata de um ajustamento mútuo entre os dois parceiros, ajustamento que pressupõe a composição de um ritmo compartilhado, uma ritmicidade conjunta. É importante notar que essa interação é imperfeita, o que a marca é a busca do ajustamento pela mãe e pelo bebê, e quando isso se dá o bebê tem a ilusão confirmada de sua auto-satisfação. $\mathrm{O}$ objeto aqui não está distinto ainda.

Pouco a pouco vai se dando também uma mudança nesse ajustamento materno, pois a mãe, como também indica Winnicott, começa a desiludir gradativamente seu bebê. Isso porque ela mesma começa a retomar seus outros investimentos e interesses, seu olhar volta-se de novo para o pai e para outros 
focos. Como irá reagir o bebê a essa mudança? Ele viverá o fracasso da ilusão de auto-satisfação, o que o deixará raivoso, agressivo contra a mãe. Aqui a resposta da mãe à raiva do bebê é fundamental. O futuro da organização da pulsão, segundo Roussillon (2010), depende da resposta do objeto, levando a uma nova fase na espiral interativa entre mãe e bebê, a uma nova etapa na dialética entre pulsão e objeto.

O destino e a intensidade da destrutividade do sujeito devem ser relacionados com a modalidade da resposta do objeto à destrutividade e são três as reações possíveis da parte da mãe: represália, retirada ou sobrevivência. Evidentemente a mais positiva é a da sobrevivência, que pressupõe uma crença da mãe de que o bebê também sobreviverá à sua ausência e à raiva que sente por ela. Ela tem confiança em seu bebê, e não se sente atacada por ele. Mas, como retomar o contato com o bebê? Aqui entra em jogo a criatividade da mãe, e a questão de sua culpabilidade. Se a mãe se sente culpada por ter deixado seu bebê, ficará reduzida sua capacidade de criar. Se, ao contrário, ela tem uma boa negociação com sua culpabilidade, e confia nas capacidades de seu bebê, será capaz de encontrar respostas criativas ao seu ataque destrutivo e à sua raiva.

Contudo, o mais importante é que ao atravessar essa experiência, o bebê descobrirá que ele não está na origem de sua própria satisfação - "há um outro sujeito, há outro desejo independente de mim", imagina Roussillon (2010) que o bebê poderia se dizer. Isso promove uma verdadeira revolução subjetiva, abrindo para a diferenciação eu-não/eu, para a existência do outro/sujeito. Nesse mesmo tempo, o bebê descobre sua dependência, pois sua satisfação depende do desejo de outro. Podemos supor que essa descoberta é um abalo profundo ao narcisismo primário, é um 'ferimento psíquico' para o bebê, que irá reagir com seus recursos desenvolvendo mais e mais suas comunicações intencionais com o objeto, visando obter por outras vias sua satisfação. Nesse processo, o bebê amplia seu repertório e enriquece suas capacidades de comunicação e de interação com o outro, de certa maneira podemos pensar que essa experiência funciona como uma alavanca para o desenvolvimento da criança.

Outra conseqüência diz respeito ao sentimento do bebê diante da ausência do objeto, que o faz sentir o quanto precisa e depende dele, suscitando sua agressividade contra o objeto, surgindo então o ódio como conseqüência do amor. 
O círculo seria então - amor ao objeto --- dependência --- ferimento ---- ódio. Nasceria aqui o conflito de ambivalência, e vemos então que tal conflito depende diretamente da sobrevivência do objeto. O conflito começará a se instaurar internamente: 'será que meu ódio irá destruir o amor pelo objeto?'.

Novas questões se abrem a partir desse ponto: a intensidade da raiva experimentada pelo bebê quando o objeto falta, a fantasia que começa a se desenhar: 'se ela não está aqui, está em outro lugar'. Abre-se também aqui o campo do brincar, e do auto-erotismo, sucedâneo da auto-sensualidade, com a diferença fundamental de que no auto-erotismo o objeto é reconhecido, amado, odiado, desejado. Outra decorrência importante da sobrevivência do objeto é a capacidade de estar só na presença do outro, indicando que o bebê começa a distinguir a percepção do objeto e a sua representação interna. Aqui o bebê pode brincar de ser sua própria mãe sem que ela seja destruída pela nova capacidade de sua criança. A mãe pode estar ao lado, absorvida por outro interesse, e o bebê se apropria do que ela lhe deu, pode se bastar e brincar ali perto dela. Aqui também o modo de resposta do objeto, sobrevivendo a essa nova situação, é exemplar. Algumas mães não suportam e rapidamente intervêm no jogo do bebê, numa forma de reação intrusiva e desqualificadora para a ação da criança. Outras se sentem feridas e abandonadas, e retiram todo seu interesse do bebê. E por fim, há a mãe que 'sobrevive', apesar de experimentar uma pequena reação depressiva, mas ela também fica narcisicamente compensada pelo progresso de seu pequeno, orgulhosa e admirativa de suas novas capacidades. Cada uma dessas modalidades de reação do objeto irá favorecer ou não a própria criatividade da criança, e sua condição de experimentar o prazer de estar só, ao lado da mãe, podendo usufruir dela como objeto interno introjetado.

Quando há fracasso nessa 'capacidade de estar só em presença do objeto' (Winnicott, 1958) é preciso se interrogar sobre o que ocorreu na dinâmica da relação primária entre o bebê e seu ambiente, anteriormente à própria experiência fracassada. Em outras palavras, os percalços das experiências de separação dependem em grande parte dos laços e dos encontros anteriores, a separação serve como revelador desses. Roussillon, Golse e outros autores contemporâneos defendem a construção de uma 'metapsicologia da presença', que envolve a modelização dos primeiros encontros entre o bebê e seu objeto primordial. $\mathrm{Na}$ 
verdade, trata-se da dupla presença/ausência, considerando "a questão do impacto da separação sobre o encontro e a presença do outro, como o impacto do encontro sobre a separação e a ausência do outro" (Roussillon, 2013, p. 224).

Essa metapsicologia da presença encontra elementos em noções e compreensões propostas por diferentes autores, que têm como ponto comum a idéia de que no encontro primeiro entre o bebê e o ambiente, representado pela mãe, seja possível a construção de uma representação de união. Foi o que Didier Anzieu (1974) propôs ao se referir à figura de uma "pele comum" entre o bebê e a mãe, que precede o "Eu-pele". Busca descrever um estado primeiro no qual a mãe pode partilhar o estado interno do seu bebê, como se esse estado fosse, por um tempo, um estado comum aos dois.

Essa pele comum contém e liga a percepção do objeto e as primeiras formas da representação do objeto 'colados juntos' em um objeto comum, forma transicional do símbolo do encontro e do impacto da presença (ROUSSILLON, 2013, p. 229-230).

Nessa mesma direção está a função proposta por Winnicott (1967) do rosto da mãe como "espelho" para o bebê, assim como seu corpo, seus gestos, seu ritmo, indicando a necessidade da mãe funcionar empaticamente com seu bebê e lhe reenviar ecos dele mesmo por suas respostas e suas mensagens, essencialmente corporais e vocais.

O que o bebê vê quando olha para o rosto da mãe? Sugiro que normalmente, o que o bebê vê é ele mesmo. Em outros termos, a mãe está olhando para o bebê e aquilo com o que ela se parece está relacionado com o que vê nele (WINNICOTT, 1967, p. 154).

A hipótese de Roussillon, retomando a proposição de Anzieu da pele comum, é de que antes de poder se diferenciar e se separar, é preciso estar reunido em uma unidade, um envelope comum. E seria num segundo momento que a percepção e a representação do objeto começariam a poder se descolar uma da outra sem danos, permitindo a experiência de 'estar só em presença do outro'; elas sobrevivem à diferenciação psíquica. Quando as experiências de separação se passam de modo satisfatório o infante pode se voltar para a representação interna do objeto ausente e desenvolver suas alternativas auto-eróticas, apoiado sobre a concepção de que o objeto ausente está presente alhures, que ele vive e sobrevive em outro lugar. Entramos aqui no campo descrito por B. Golse (2001) como 
sendo o das relações, que é marcado pelo conflito psíquico interno e pela relação que o bebê estabelece com o objeto e indiretamente com o 'objeto do objeto'.

Em resumo, para chegar ao estado descrito por Winnicott (1958) como a capacidade de estar só em presença do objeto, o que equivale a poder esquecer o objeto em sua presença, é preciso que este tenha sido suficientemente presente de maneira confiável. Segundo o pensamento de Winnicott a base da capacidade de estar só em presença de alguém depende essencialmente da capacidade da mãe, ela própria, de estar só em presença de sua criança, sem nada exigir dela. É somente nessas condições que o bebê poderá simbolizar sua ausência; de outro modo, a perda sentida por ocasião da separação não produzirá simbolização, mas somente desamparo.

\section{2}

\section{Da sensorialidade à simbolização}

Uma questão crucial em relação aos processos de subjetivação é a de compreender como se dá a passagem das inscrições e dos vividos no corpo, no registro da sensorialidade, para o registro do psiquismo propriamente dito, relacionado com as capacidades de representação e de simbolização.

\subsection{1}

\section{A sensorialidade e o psiquismo fetal}

Numerosos trabalhos têm demonstrado a existência de uma sensorialidade fetal. Está claro atualmente que os cinco sentidos humanos se desenvolvem seguindo uma ordem invariável durante a vida intra-uterina, em primeiro lugar o tato, depois o olfato e o paladar, em seguida a audição e por fim a visão. Além disso, as pesquisas concordam em que, mesmo se todos não alcançam a maturação antes do nascimento, esses sistemas sensoriais já se mostram funcionais ainda no útero. Também, os estudos das últimas décadas sobre a vida intra-uterina evidenciaram a existência de uma percepção pelo feto de elementos de seu ambiente, tanto intra-uterino como externo. (Busnel \& Herbinet, 1982).

Nesse sentido, as pesquisas dão indícios interessantes sobre a sensorialidade fetal e sobre os registros de memória de curto prazo logo após o 
nascimento, que poderíamos chamar de proto-simbólicos, pois seriam as primeiras marcas, os primeiros sulcos sobre os quais viriam se associar as experiências pósnascimento. Sabemos que o feto vive, já no útero, breves experiências de descontinuidade, relacionadas, por exemplo, à apresentação de estímulos sonoros vindos do interior do corpo materno ou do ambiente externo que atravessam a parede uterina de proteção. Também são observadas movimentações espontâneas do feto e reações de caráter defensivo diante de estímulos luminosos que são apresentados no interior do útero (Lecanuet et al, 2004).

Ainda no útero o feto vai recebendo estímulos táteis, sonoros, oriundos do corpo materno. Podemos supor que ele vai assim constituindo uma primeira e rudimentar experiência sensorial desse outro, ainda não percebido enquanto tal. Com a ruptura do nascimento, o que subsiste como referência para o bebê que permite a ele se orientar nesse novo meio provém desses registros sensoriais. Os estudos da etologia humana (Cyrulnik, 1999) trazem algumas informações interessantes sobre esses primeiros marcadores sensoriais do bebê, que, poderíamos pensar, operam como espécies de pré-constituintes de seu aparelho psíquico nascente. Esse primeiro tempo, o das interações precoces, inicia-se nas primeiras semanas de existência do feto, e vai se enriquecendo progressivamente até o nascimento e durante o primeiro ano de vida.

A primeira via sensorial que chega à maturidade e entra em função é o tato, a partir da sétima semana in útero; é uma pressão mecânica, uma mudança de postura (...) são estimulações essencialmente físicas (...) Em seguida, na décima primeira semana, o gosto e o olfato entram em função. E, num mundo aquático, ... a água é um excelente condutor de sons que ela traduz em vibrações e em toques. (...) Num mundo marinho o som é uma carícia, uma vibração, sobretudo as baixas frequiências que são um tocar nos lugares mais sensíveis do corpo do bebê, em torno da boca e nas mãos, primeiros locais tácteis mielinisados. Assim, a via final comum de todas as vias sensoriais nessa etapa do desenvolvimento é o toque (...). A audição entra em função por volta de vigésima oitava semana. (CYRULNIK, 1999, p. 241)

As observações indicam a existência de uma memória de curto prazo em final de gravidez, que faria com que a criança já pudesse levar em conta as palavras maternas recebidas como objetos sensoriais, que tocam como uma pressão. Outros estudos realizados por ecografistas mostram que os bebês reagem com movimentos à percepção das baixas frequiências da voz materna. No final da gravidez a audição, o gosto e a olfação estão suficientemente desenvolvidos para 
oferecer ao recém-nascido algumas referências, “(...) uma pequena experiência sensorial de sua curta memória que dura alguns minutos, mas que permite a ele não se encontrar como um marciano que desembarca na terra" (Op. cit., p.243), ao nascer. O que quer dizer, segundo Cyrulnik, que esse ser anfíbio que deixa seu mundo aquático para se tornar um ser terrestre

...reconhece as estruturas sensoriais que ele havia percebido anteriormente sob a forma de baixas frequiências, de tonalidades, de odores, de gostos; em poucos dias, a criança tem um pequeno grasping sensorial ao qual ele vai poder se agarrar. É aquilo que Daniel Stern considera que dá início ao sentido de si (sens de soi) (CYRULNIK, 1999, p. 243).

Há uma peculiaridade do bebê humano que o coloca em estado de dependência total dos cuidados externos: nasce com seu dispositivo sensorial, sensorialidade que começou bem antes do nascimento, mas é impotente do ponto de vista motor. Um mundo sensorial rico, com cheiros, cores, brilhos, o esboço do formato do rosto, contrapõe-se a uma pré-maturidade motora que o obriga a uma radical dependência. “(...) Assim, biologicamente, o pequeno humano é forçado à alteridade". (Cyrulnik, 1999, p. 244).

Como recursos atuais que nos aproximam do 'bebê de dentro' temos as ecografias; os achados clínicos que fazem supor registros primários das experiências da vida fetal; os procedimentos da haptonomia; todos eles são aproximações no sentido de construirmos hipóteses sobre a experiência própria do feto. Dentro do referencial psicanalítico, a frase de Freud (1926) a respeito da continuidade entre a vida fetal e a vida após o nascimento indica que ele já considerava a hipótese de uma dimensão de vida proto-psíquica intra-útero.

No embrião o desenvolvimento se dá seguindo o ritmo da embriogênese. O embrião, depois feto, adquire progressivamente as grandes funções biológicas cuja maturação pode ser verificada pela observação e pela medida das variações e ondulações rítmicas. Esse desenvolvimento se dá acompanhado do ritmo regular dos batimentos cardíacos maternos, e pela sustentação tônica da parede uterina, qui transmite e amortece as mensagens proprioceptivas e sonoras através do líquido aminiótico.

Apoiado numa programação genética, em interação permanente com os ritmos físicos e psíquicos da mãe, o feto cria movimentos rítmicos singulares. Desde muito cedo ele demonstra uma atração por eventos rítmicos externos 
(Lecanuet et al, 2004). A hipótese de S. Maiello (1991) sobre a alternância da presença e ausência da voz materno no útero como uma proto-experiência da presença/ausência do objeto materno pós-natal abre a gênese objetal psicanalítica do bebê em seu primeiro capítulo pré-natal, esse proto-objeto prénatal da voz materna constituindo com as trocas proprioceptivas um dos componentes da "relação de objeto virtual pais-feto" (Missonier, 2004)

Os primeiros receptores tácteis tornam-se funcionais já na sétima semana do desenvolvimento embrionário na região peribucal, e essa sensibilidade se estende depois, a partir da décima-primeira semana para todo o rosto e para os dedos. Em torno de 14 semanas ela já está presente em todo o corpo, com exceção das costas e do crânio, que estão em contato com a parede uterina. A sensibilidade no início é preferencialmente ventral. (Wolff-Quenot, 2001, apud Prat, 2007).

A precocidade do desenvolvimento do tato aponta-o como o primeiro órgão de transmissão das informações sobre o mundo, o que leva Prat (2007) a supor que seja a primeira base do desenvolvimento psíquico. As informações sobre o mundo se fariam em termos de presença/ausência do contato.

Se acreditarmos na lei que enuncia que quanto mais um órgão se desenvolve precocemente, mais ele será fundamental, o revestimento externo do corpo e o revestimento interno do tubo digestivo são essenciais; sensibilidade táctil, sensibilidade digestiva ou respiratória, todas sujeitas aos fenômenos alérgicos. (WOLFF-QUENOT, 2001, apud Prat 2007). (grifos do autor)

A pele então é o primeiro dos órgãos dos sentidos e também o maior de nossos meios de comunicação com o exterior. A singularidade da pele como órgão dos sentidos em relação aos outros é a sua reciprocidade: ao tocar também se é tocado, o contato supõe e inclui o encontro e essas são a primeiras sensações percebidas no desenvolvimento do embrião.

Desde o início da vida, as primeiras experiências sensíveis são então inscritas em uma dualidade e feitas da alternância entre 'estar em contato' e 'estar sem contato'. Elas são indissoluvelmente ligadas à ritmicidade dos encontros com o que se tornará o outro, à medida que progride o desenvolvimento, mas que está presente no plano sensorial desde a origem (PRAT, 2007, p. 106) .

Segundo a concepção de Prat (2007), as primeiras excitações que deverão ser transformadas vêm dos elementos tácteis, na alternância entre contato/perda de contato, criando um modelo de base, que será o protótipo para os demais órgãos dos sentidos, os quais virão alargar a paleta das modalidades perceptivas ligadas a 
estar em contato/estar sem contato. Nessa concepção, o ritmo primordial é o da presença e da ausência do outro, provavelmente vivido nas experiências arcaicas de 'seguro/deixado', cuja alternância vai demandar uma organização que restabeleça a continuidade. Esse ritmo primordial do 'seguro/deixado' vai também se manifestar nas demais atividades sensoriais quando elas se tornarem funcionais, a olfação, o paladar, a audição e por fim a visão, e que permitirão manter o contato com o objeto à distância.

As experiências clínicas da haptonomia revelam uma busca de contato ativa de parte do bebê no útero: assim, quando a mãe "chama" seu bebê aplicando a palma da mão em diferentes pontos do seu ventre e imprimindo leves pressões rítmicas, o bebê se desloca e vem colocar sua cabeça na mão da mãe, através da parede abdominal. Em seguida ele irá seguir a mão em seus deslocamentos. Isso leva a perguntar qual é essa relação, como é esse bebê que ainda não nasceu e que dá a impressão de buscar ativamente o contato com o outro, com a mãe. Que necessidade tem ele de um outro, sendo que ele está dentro de um meio que é suposto atender a todas as suas necessidades? Para Prat (2007), essas experiências confirmariam a existência de uma necessidade primária de contato, tal como Bowlby a conceitualizou.

Préconcepção do objeto. Ainda no útero o bebê ensaia atividades 'autonomas', como por exemplo, iniciar contatos com as paredes do útero, 'brincar' com o cordão umbilical, jogar com as mãos uma gota de sangue que flutua no útero após um exame do líquido amniótico, atividades que parecem ser formas primárias de 'segurar/lançar'. Para Prat (2007), elas são indissociáveis do vínculo com o outro e já colocam em cena a alternância entre presença e ausência do objeto. $\mathrm{O}$ mundo intra-uterino oferece possibilidades de experiência ricas e variadas consigo mesmo e com os elementos do útero, tais como:

- objetos acessíveis diretamente (a placenta, por ex.)

- objetos indiretamente acessíveis (contato com a mão da mãe através da parede abdominal)

- é observado que o feto chupa seu polegar no útero, demonstrando que se trata de uma experiência primária, e não a reativação de traços mnésicos ligados à 
satisfação da fome. Essa atividade auto-sensória do feto prosseguirá após o nascimento, indicando a continuidade das experiências pré e pós-natais.

- a partir do $3^{\circ}$ mês o feto engole líquido amniótico, cujo gosto varia em função da alimentação materna; depois do nascimento, experiências mostraram a preferência dos bebês indianos pelo curry, ou pelo alho os bebês do mediterrâneo. Indicam uma configuração primitiva complexa entre toque - movimento -paladar- olfato.

- a visão só estará funcional após o nascimento, mas o feto desde o $7^{\circ}$ mês movimenta os olhos, abre e fecha as pálpebras; ele percebe as luzes fortes e se afasta delas. Ele consegue alterar suas percepções visuais abrindo e fechando as pálpebras, o que poderia também indicar uma pré noção de presença/ausência.

Admitir que as bases, ou os mecanismos íntimos da transmissão psíquica possam se iniciar desde o período fetal da vida remete à hipótese de uma certa continuidade da vida psíquica antes e depois do nascimento, como faz supor a frase clássica de Freud "Há muito mais continuidade entre a vida intra uterina e a primeira infância do que a impressionante cesura do ato do nascimento poderia nos fazer acreditar” em Inibição, sintoma e angústia (Freud, 1926, p. 19). Hoje, pode-se pensar que a dimensão arcaica do funcionamento sensitivo-sensorial do feto constitui uma fundação da atividade tradutora da vida psíquica posterior.

Em relação à gênese pré-natal do objeto, como é possível pensar? Como sabemos que a sensorialidade fetal se desenvolve de maneira programada durante a gravidez, trata-se de considerar os traços sensoriais que poderiam pré-figurar uma relação de objeto, a partir de primeiros registros parciais e arcaicos. É nesse sentido que a hipótese de S. Maiello (2000) tem um grande interesse, ao sugerir que as descontinuidades da voz materna, que chegam ao feto através da parede abdominal e uterina, lhe forneceriam uma pré-forma da problemática posterior da dupla ausência/presença do objeto na vida pós-natal.

Maiello (2000) propõe que o encontro com os sons permite ao feto experimentar as diferenças entre os ruídos de fundo, regulares e permanentes e os sons aleatórios. A percepção da voz materna poderia representar a primeira experiência de alteridade do feto durante a vida prénatal, já que ele não tem nenhum poder sobre sua presença ou sua ausência. A partir de seus trabalhos sobre os bebês e os dados da vida fetal que mostram que os bebês percebem os 
ruídos um mês antes de perceber as vozes, Maiello (2000) considera que "os momentos iniciais da emergência e da diferenciação do aparelho mental em relação ao estado primordial de união fusional psicofísica são aqueles ligados à dimensão acústica”. Prat (2007), por seu lado, pensa que a nova forma sonora se ligaria a uma préconcepção do mundo e do objeto que já vinha se desenhando anteriormente a partir do tato. Ela sustenta que as primeiras características de presença/ausência são informadas pelo tato, e que irão constituir o primeiro trabalho psíquico de simbolização primitiva.

Sabemos que no útero o feto percebe alguns sons, que certamente ele tem dificuldade em discernir se são internos ou externos, já que esses últimos também chegam a ele pelo corpo materno. Mas alguns sons são regulares e ritmados, como os ruídos do coração materno, outros são irregulares, como os ruídos digestivos, porém os sons de fora são obviamente irregulares e imprevisíveis (barulhos do ambiente externo, vozes de adultos e especialmente a voz materna). Para S. Maiello (2000), a irregularidade da percepção da voz materna prefiguraria a problemática da ausência e da presença que irá tomar forma de modo central após o nascimento, durante o processo de diferenciação sujeito/objeto que a criança irá viver.

Caberia uma discussão se é realmente legítimo privilegiar dessa forma o objeto sonoro, pois autres objetos sensoriais fetais poderiam também ser compreendidos nessa perspectiva, como indica Prat (2007) em relação ao tato. Anteriormente B. Golse (2006) havia proposto uma discussão sobre a teoria do $a$ posteriori desde o período pré-natal, na medida em que seriam as inscrições sensoriais no feto que constituiriam o primeiro tempo de um traumatismo construtivo e estruturante, primeiro tempo em espera do encontro pós-natal com as irregularidades da presença do objeto externo, que seria então um segundo tempo dessa experiência do desenvolvimento emocional. $\mathrm{O}$ autor sugere que essa hipótese retoma a tripartição dos processos psíquicos descrita por P. Aulagnier, dos pictogramas até os enunciados, passando pelos cenários fantasmáticos, correspondendo aos registros originário, primário e secundário (Aulagnier, 1975).

Se o encontro com o objeto externo, após o nascimento, permite uma retradução dos traços mnésicos pictográficos prénatais, suscetível de fazer surgir a idéia do objeto e da descontinuidade de sua presença, isso somente é possível 
por causa da atividade psíquica do objeto, num encontro marcado pela reciprocidade e pela assimetria de duas psiques, a da criança em curso de estruturação, e a do adulto, da mãe, já estruturada. (Golse, 2006). Essas compreensões levam a situar o início do trabalho do psiquismo à necessidade, para o bebê, de tratar e de transformar as primeiríssimas informações sensoriais, as primeiras 'excitações', que se tornarão posteriormente as excitações pulsionais (Prat, 2007).

No campo da clínica psicosomática, autores como J. Bergeret e M. Houser (2004, apud Missonier 2009) sugerem que as "lembranças/não-lembranças", hipotéticos traços sensoriais do período fetal, proto-representativos, que não são posteriormente simbolizáveis diretamente, possam estar ativos na homeostase psicossomática do sujeito e nos conflitos ligados à dialética conteúdo/continente de expressão narcísica. Nessa mesma direção, psicossomaticistas como P. Marty e pediatras neonatologistas como N. Boige buscam estabelecer relações entre os quadros alérgicos dos indivíduos ou os sintomas precoces dos bebês com os registros da vida fetal, no limite entre o biológico e o psíquico. Marty (1998) descreve o lugar da função materna na organização psicossomática do bebê estendendo-a ao período pré-natal, sobre a base dos ritmos biológicos. Ele considera que essa organização é dependente da qualidade e da quantidade de investimento libidinal da mãe, e é infiltrada pelo inconsciente materno, e isso desde o período pré-natal. Lembra que certas funções têm um papel importante in útero (as trocas humorais entre a mãe e o feto) e no nascimento (tais como a pele e a respiração). O feto constitui fixações imunológicas para as quais pode haver regressão, como manifestações cutâneas e respiratórias no sujeito alérgico, descrito como fixado a uma relação objetal fusional, visando uma indistinção com o objeto, e de essência humoral, a exemplo das interações entre o feto e a mãe.

Pode-se conceber, por exemplo, que nos momentos arcaicos da evolução individual, durante a vida intra-uterina, conflitos existam, talvez de ordem imunológica, na relação com a mãe. Esses conflitos, perturbando a programação do desenvolvimento fetal, remetem à fixações-regressões intra-sistemicas que marcam então toda a vida do individuo, criando muito cedo pontos de apelo regressivos. Além de transmissões hereditárias do mesmo tipo, compreendemos desta maneira o início pré-natal da organização alérgica do sujeito (MARTY, 1958, p. 28). 
Nathalie Boige (2004) propõe que o estudo do pré-natal pode dar sentido aos sintomas somáticos precoces apresentados pelos bebês, incidindo sobre as funções biológicas principais como a alimentação, o sono, o ganho de peso, o trânsito digestivo. Tais sintomas podem ser lesionais e/ou funcionais, mas sempre apontam para a inter-relação estreita do somático e do psíquico, pois dificilmente no bebê é possível separar o somático do psíquico, o sintoma do bebê é quase sempre "psicossomático". Da mesma forma, é impossível separar o sintoma do bebê da mãe, ou da tríade, o sintoma se inscreve nas interações entre os pais e o bebê. Diz N. Boige "o bebê nos conta com seu corpo alguma coisa de sua história e da história de seus pais" (Boige, 2004, p.257).

Enquanto pediatra, ela aponta como as observações durante consultas pediátricas de bebês manifestando sofrimentos psicossomáticos, tais como os sintomas de refluxo gastro-esofágico, revelam perturbações nas interações, nos ritmos entre mãe e criança, que se originam já no período pré-natal, remetendo à ambivalência materna inerente à toda gravidez, muitas vezes não reconhecida. Ao escutar os pais na consulta pediátrica, Boige (2004) correlaciona o sintoma do bebê a angústias latentes da mãe diante de seus próprios movimentos de ódio ou de sua ambivalência mal elaborada desde a gravidez.

Essa breve resenha de vários estudos sobre o período pré-natal indica que o bebê ao nascer não é uma tabula rasa, mas aborda o mundo já com um certo número de pré-concepções, ou virtualidades, competências, como formas primeiras em busca de atualização para se tornarem utilizáveis. Essas formas influenciam a percepção e o investimento do ambiente e dos encontros com o objeto, como também as futuras transformações integrativas das experiências. Nessa perspectiva a atividade auto-sensória do bebê recém-nascido, na continuação da atividade auto-sensória do feto, poderia ser vista como precursora de uma atividade representacional, necessária para a construção de sua narratividade.

Somos seres tecidos de histórias, situados na dimensão do tempo, de nossas origens e com a consciência de nossa finitude. Se o tempo da gestação é nosso primeiro capítulo, quais narrativas compõem essa escrita? As histórias infantis de cada um dos pais, revisadas durante o tempo da gestação, serão parte das tramas que irão compor as primeiras letras da identidade narrativa do bebê por 
vir. Cabe perguntar se nessa composição os registros primeiros, da memória corporal do feto, farão também parte dessa primeira escrita.

Por outro lado, os estudos recentes sobre as condições para os processos de subjetivação enfatizam a importância fundamental do ritmo compartilhado entre a mãe e a criança. Assim, estabelecendo conexões entre os ritmos percebidos pelo feto na vida intra-uterina e os ritmos das interações corporais e vocais com a mãe após o nascimento, desenham-se hipóteses para compreender essas bases iniciais das interações primárias, que servirão ao bebê como referências constitutivas em sua integração das experiências sensoriais e relacionais.

\section{2 .2}

\section{Sensorialidade e atividade psíquica}

O bebê constitui sua subjetividade a partir de suas experiências corporais. Winnicott (1949) enfatiza a importância do processo de personalização, que implica o estabelecimento de ligações entre a psiquê e o corpo. Muitas experiências sensoriais e corporais do bebê nascem em torno dos cuidados, nos quais a criança é passiva, objeto de investimento de seu objeto primordial, em geral a mãe. Todo o processo de subjetivação implica a paradoxalidade de ter origens exteriores a si, mas também partilhadas com os objetos do ambiente. Nessa experiência prevalece a ilusão temporária de uma indiferenciação entre o fora e o dentro. O processo de subjetivação no bebê se faz então pela aceitação e apropriação de suas experiências sensoriais, mas também pela apropriação das experiências sensoriais partilhadas com os adultos de seu ambiente. Trata-se então de tentar compreender como os primeiríssimos laços psíquicos, especialmente aqueles que emanam da sensorialidade, intervêm nos processos de subjetivação.

Em um bebê a experiência sensorial passa a ser um fator subjetivante na medida em que se dá uma adequada integração de suas polisensorialidades com o papel rítmico integrador do ambiente materno (Golse, 2006) e que ele experimenta a vivência de um pleno compartilhar afetivo. Nesse tempo dos laços iniciais os sujeitos e objetos psíquicos, compreendidos como componentes de uma relação objetal, não estão ainda constituídos no bebê. Eles se organizarão como 
tais a partir desses primeiros vínculos, assim como irão se definir os espaços internos e externos. Nesse momento, o objeto não existe para o bebê enquanto outro, ele é investido de uma maneira totalmente narcísica.

No bebê muito pequeno as experiências psíquicas se mostram pouco integradas, não coordenadas. A subjetividade se compõe a partir de forças, impulsos e movimentos sentidos inicialmente de uma maneira difusa, e são os aspectos quantitativos, de intensidade, que predominam sobre os aspectos qualitativos. O campo das representações, que podem ligar os afetos, não está constituído ainda. Bion (1979) propõe que é a capacidade de reverie materna e sua função alpha que irão pouco a pouco permitir que esses dados sensoriais brutos possam tornar-se produções representativas, internalisadas e metabolisadas gradativamente pelo psiquismo nascente do bebê. Essa capacidade do psiquismo materno de contenção e de transformação leva-a a metabolizar e transformar as primeiras produções ou protoproduções psíquicas de seu bebê a fim de torná-las utilizáveis por ele. Essa função materna necessita uma identificação primária com seu bebê, a quem a mãe empresta seu aparelho para pensar pensamentos, isto é, seu aparelho para tornar pensáveis pela criança seus primeiros pensamentos, impensáveis por ela sozinha. Esse processo pode ser descrito em quatro tempos. O primeiro é aquele no qual a mãe recebe as tensões da criança, seguido de um segundo durante o qual ela guardará por um período suficiente aquilo que lhe foi endereçado, experiência que permite ao bebê vivenciar que o que ele sente pode ser recebido por um outro, que ele pode tocar sem destruir. O terceiro tempo é o da transformação, no aparelho psíquico da mãe, dessa tensão do bebê que ela recebeu e guardou. Essa é a função de metabolização, que Bion chamou de função alpha. O quarto tempo é aquele da restituição ao bebê do que foi transformado pela mãe, transmitido por meio de gestos, palavras e outras formas de comunicação. O bebê passará progressivamente a fazer ele mesmo esse papel de metabolizar os elementos não pensáveis de seu psiquismo, ao internalizar essa capacidade materna de receber, guardar e transformar, processo que é constituinte, segundo Bion, do aparelho de pensar da criança.

O estudo das sensorialidades é ainda relativamente recente na psicanálise, e são em parte as contribuições da clínica dos primórdios e os estudos sobre o psiquismo perinatal que têm contribuído para seu desenvolvimento. Podem ser 
descritas como o conjunto das experiências psíquicas que se expressam em torno dos órgãos dos sentidos. A. Konicheckis (2008) propõe considerar a sensorialidade como o complemento libidinal da percepção, sua face afetiva.

O sensorium se forma essencialmente sobre as superfícies de encontro entre partes do corpo e objetos do mundo externo, e encarna toda a ambigüidade da noção de 'partilha', ao mesmo tempo encontro e separação. Fenômeno de contato entre o fora e o dentro, portanto, a sensorialidade comporta igualmente os laços que se estabelecem entre a psique e o soma (KONICHECKIS, 2015, p. 6).

As primeiras experiências sensoriais do bebê são fragmentadas e descontínuas, e será a atividade psíquica que deverá ligá-las. As satisfações e as inadequações de parte dos adultos que cuidam do bebê, por falta ou por excesso, são experimentadas por ele como uma experiência sensorial. A pele ganha aqui uma importância muito grande, pois possui a faculdade de conter e de ligar todos os órgãos dos sentidos, e favorece assim a constituição de uma integração, como afirmam E. Bick (1968) e D. Anzieu (1985). Não é possível supor no bebê experiências que se passem fora da sensorialidade. Como afirma Golse (2002a) os sentidos despertados confirmam a presença de um objeto.

O ser psíquico do sujeito bebê poderia ser definido pela intensidade de suas sensorialidades, que instauram um espaço pessoal e fundador do sentimento de si. Elas tratam de uma experiência íntima, única para cada bebê e dificilmente transmissível. O sensorium delimita e cria uma espécie de cartografia que permite estabelecer os limites, as fronteiras, as diferenciações entre si e os outros a partir de uma experiência interna, própria, pessoal, mesmo se ela é tão múltipla quanto variada. Antes do nascimento a criança é envolvida por um meio que produz sensações cenéstésicas, auditivas e gustativas. Depois do corte do nascimento, a criança reencontra sensações mais ou menos em continuidade com aquelas que ela sentia antes: o tom das vozes, a cadência dos movimentos, os batimentos cardíacos e os ritmos corporais. Nos momentos de afastamento do objeto o que a criança perde não é a figuração da pessoa de sua mãe, mas sim as experiências sensoriais que ela partilhava com a mãe. O sentimento de identidade pessoal se cria então a partir da atividade psíquica sensorial, e Konicheckis propôs a noção de identidade sensorial (Konicheckis, 2000) referindo-se a essas características das experiências sensoriais que compõem pouco a pouco a identidade própria de cada ser. 
Assim, o bebê cria seu conhecimento dos objetos pelos efeitos sensoriais que eles provocam, pois no início ele sente as sensações e as modalidades perceptivas, e não o objeto do qual ela emanam. Em seu texto sobre a negativa, Freud (1925) lembra que o julgamento de atribuição, que diz respeito às características do objeto, precede o julgamento de existência, o que decide se o objeto existe ou não na realidade externa.

O materno, enquanto qualificativo, precede a formação psíquica da representação da mãe. O bebê muito pequeno se deixa carregar pelos braços dos adultos que o cercam. Ele se abandona e adere à forma dos corpos que o sustentam. Seu sentimento de continuidade de existir se apóia sobre outros corpos e pelo prolongamento nesse outro espaço.

Myriam David (2014) sustentava que nos primeiros anos de vida da criança sua motricidade espontânea e as vivências sensoriais de seu corpo permitem a ela toda uma série de descobrimentos. A atividade psíquica do bebê estaria contida e se exerceria a partir de sua sensório-motricidade, ambos os fatores estando em contínuo processo de integração para desenvolver o psiquismo. Em suas palavras:

Por psiquismo eu entendo essa força interna que habita em nós, misteriosa, invisível e impalpável, em atividade perpétua e permanente, em busca de processos de "funcionamento", de "regulação", de "organização". ...Durante os primeiros anos, o que se dá com o psiquismo também se dá com o desenvolvimento motor do bebê. É ele mesmo, e somente ele, o bebê, que o elabora a cada dia, "a pequenos passos", utilizando os recursos que lhe são oferecidos gradualmente, de um lado pelo estado de desenvolvimento e pela integridade de seu aparelho neuro-sensório-motor, e, é claro também, por seus encontros interativos e intersubjetivos com o ambiente próximo, material e humano, do que ele "se" alimenta. Para fazê-lo, o bebê dispõe dessa única, mas extraordinária ferramenta que é seu aparelho neuro-sensório-motor no estágio de desenvolvimento no qual ele se encontra (DAVID, 2014, p.280).

Essa força de atividade permanente e dinâmica em busca de processos de organização e ligação tem como ponto fundamental o encontro com o outro, com as características de sua ritmicidade e narratividade. Esse início da vida é de certa maneira o reino da sensorialidade, da motricidade e do ritmo, ancorados no corpo e no contato com o outro.

Partimos da base de uma sensorialidade inata do bebê que une o interior e o exterior por intermédio dos órgãos sensoriais e das excitações que recebem e geram sensações. Essa sensorialidade primitiva configuraria fluxos sensoriais (D. 
Houzel, 2002) inicialmente indiferenciados. As excitações serão diferenciadas, coordenadas e integradas pelo papel do outro subjetivante, que ao refleti-las, espelhá-las e traduzi-las, possibilitará que se crie uma 'ritmicidade conjunta' no vínculo. É o ritmo que funcionará como organizador dessas polisensorialidades. (Golse, 2010).

Um dos pontos a enfatizar nos estudos sobre o bebê é a relativa discrepância entre, de um lado, sua "aptidão" sensorial, e, de outro, sua "incompetência" motora, o que parece levá-lo a precisar, literal e metaforicamente, do corpo, dos braços do outro. Dentro do campo da psicanálise, lembramos Winnicott, que ao descrever a função materna, serve-se de um vocabulário corporal quando fala em "holding", em "handling" como meios fundamentais para dar ao bebê humano sua consistência numa continuidade de existir.

As conceituações de Didier Anzieu (1985) sobre o Eu-pele e o envelope psíquico, e de Esther Bick (1968) sobre a pele psíquica oferecem modelizações interessantes a respeito dessa passagem entre sensorialidade e simbolização. As duas noções, de envelope psíquico e de pele psíquica, apontam para o papel da função continente do objeto externo internalizado.

Anzieu (1985), ao propor a noção de "Eu-pele", busca reintroduzir dentro do campo teórico da psicanálise a dimensão do corpo, considerado por ele recalcado no pensamento psicanalítico. O Eu-pele teria uma dupla origem, epidérmica e proprioceptiva, e a partir dela estabelecem-se as primeiras barreiras defensivas que filtram as trocas, tanto internas quanto com o mundo externo. Foi definido por Anzieu (1985) como uma

... figuração da qual o Eu da criança se serve durante as fases precoces do seu desenvolvimento para se representar a si próprio como Eu contendo os conteúdos psíquicos, a partir de sua experiência da superfície do corpo...isso corresponde ao momento em que o Eu psíquico se diferencia do Eu corporal no plano operativo, mas permanece confundido com ele no plano figurativo (ANZIEU, 1985, p.39).

As três funções principais do Eu-pele foram definidas no artigo de 1974, (Anzieu, 1974) e correlacionadas diretamente com as proposições de Winnicott sobre o desenvolvimento emocional primitivo e as funções da mãe. A primeira dessas funções é a da manutenção do psiquismo, ligada ao fato de a pele sustentar 
os músculos e o esqueleto, e se desenvolver por interiorização do holding materno. A segunda relaciona-se com o fato de a pele recobrir todo o corpo, assim o eu-pele envolve o psiquismo e o contém, desenvolvendo-se igualmente pela interiorização do handling materno. A terceira função é a de proteção contra os estímulos externos excessivos, função de pára-excitação.

Na leitura de R. Roussillon (2007) a problemática central tratada pelo Eupele é aquela da diferenciação eu/não-eu, já que sua função é a de oferecer uma primeira forma de delimitação entre o Eu e seu ambiente. A segunda diferenciação tratada pelo conceito é a que se dá entre o Eu psíquico e o Eu corporal, porém esses processos não podem se passar, lembra Roussillon, "sem um tempo prévio, o da construção de uma pele comum entre a mãe e o bebê" (Roussillon, 2007, p. 95). Essa pele comum é diretamente dependente da qualidade dos cuidados maternos, e das satisfações dadas à pulsão de apego e à comunicação precoce que ela subentende. Está aqui em primeiro plano o campo sensório-motor, sendo uma primeira forma de 'compartilhar de afetos'.

Em relação à dimensão da reflexividade, o desafio primeiro colocado pelo Eu-pele seria justamente o de (se) sentir, e o bebê aprenderia a (se) sentir a partir da maneira com a qual ele é sentido por seus objetos primordiais; em seguida, tratar-se-ia do se ver, e também aqui o bebê aprenderia a se ver a partir da maneira como ele é visto. O mesmo valeria para ser ouvido e se ouvir. D. Anzieu (1985) enfatiza que a pele representa o primeiro modelo da reflexividade, pois ao tocar o sujeito percebe-se de fora pela parte que toca, e de dentro pela parte que é tocada. Para Roussillon (2007), “o interesse do paradigma da reflexividade é o fato de abrir sobre a questão do lugar do objeto no nascimento e nas formas" (Roussillon, 2007, p. 101) que ela apresenta. "Se a forma "se sentir" é a primeira da reflexividade, como pensar aí o lugar do objeto?" (Roussillon, loc. cit.). A partir da suposição da 'pele comum' desempenhando uma regulação 'transicional' no seio da unidade dual mãe-bebê, pode-se completar descrevendo a função do objeto na passagem da sensório-motricidade inicial ao afeto sensório-motor, que adquire valor de mensagem. Esse compartilhar sensório-motor opera por meio de micro trocas e ajustamentos micro-posturais entre o bebê e a mãe, e poderíamos completar que ele opera também a partir da ritmicidade conjunta que se constitui entre ambos, e "permite dar progressivamente à experiência sensorial o valor de 
uma mensagem, e portanto de um "significante" psíquico" (Roussillon, 2007, p. 102).

É a passagem progressiva da experiência corporal ao estatuto de mensagem intersubjetiva que me parece estar na origem do descolamento da pele a pele inicial, do descolamento da pele de um e da pele do outro, ao mesmo tempo em que se opera a passagem e a transformação do propriamente corporal à representância psíquica, que será, ela, capaz de se perceber como representação psíquica, como representação de si ou de momentos de si (ROUSSILLON, 2007, p. 102).

Assim se daria a passagem do Eu-pele corporal ao Eu-pele psíquico, representante do envelope psíquico do sujeito, e também do encontro com o objeto. Essa compreensão proposta por Roussillon (2007) descreve exatamente o deslizamento do corpo para o psiquico, para o campo das primeiras representações, nos processos iniciais de diferenciação entre o sujeito e o objeto.

Nesse sentido, podemos perceber o quanto Anzieu (1985) contribuiu para colocar a questão dos limites no centro da psicanálise. Sua abordagem dos limites remodelou nossa concepção do psiquismo em relação à experiência sensorial e à continência psíquica do outro, primordial para que o sujeito constitua seu envelope psíquico. O Eu-pele metaforiza assim, ao mesmo tempo, a intimidade sensorial e a função materna.

Antes de Anzieu, mas dentro da mesma perspectiva que enfatiza a relação do corpo com a constituição do psiquismo da criança, Esther Bick (1968) havia proposto a noção de "pele psíquica", objeto continente introjetado pelo bebê que delimita as fronteiras entre o interno e o externo. Segundo essa concepção, a função primária da pele do bebê é a de unir as partes do corpo ainda não diferenciadas e não integradas. Em sua forma mais primitiva essas partes da personalidade são sentidas como não tendo nenhuma ligação entre si e são mantidas unidas, passivamente, pela pele funcionando como limite. Essa função de contenção das partes não-integradas do bebê depende da introjeção inicial de um objeto externo, (mãe/seio), que dará lugar à fantasia dos espaços interno e externo. O objeto continente introjetado é experimentado como uma pele - tem a função da "pele psíquica", limite e fronteira entre o interno e o externo. Apenas mais tarde a identificação com essa função do objeto substitui o estado nãointegrado e dá origem à fantasia de espaços internos e externos, e só então a 
criança poderá se servir dos mecanismos de cisão e idealização. Até então a identificação projetiva segue sendo o mecanismo psíquico dominante.

Esther Bick (1968) propõe elementos para a diferenciação entre os estados de não-integração, enquanto experiência passiva de total desamparo, e os de desintegração, que já envolve uma operação defensiva ativa, por meio dos processos de cisão. Faz referência à mesma distinção estabelecida por Winnicott (1969) ao descrever os processos de desenvolvimento emocional primitivo, e associa as ansiedades catastróficas ao estado de não-integração, enquanto as ansiedades persecutórias e depressivas já indicam uma primeira organização do aparelho psíquico. O desenvolvimento insuficiente dessa função da pele pode ser atribuído a falhas de adequação do objeto, e podem levar ao desenvolvimento de uma "segunda pele", por meio da qual a criança se mostra numa pseudoindependência, usando inapropriadamente certas funções mentais, com o propósito defensivo de criar um substituto para essa função de pele continente.

Segundo E. Bick o bebê vai viver, com o nascimento, uma sensação de perda do continente, concomitante à descoberta do peso, como uma sensação de queda ou de 'explosão', ou melhor, de escoamento por perda dos limites continentes. Seriam as angústias mais primitivas, e o bebê precisará encontrar no ambiente um objeto continente ótimo "que apazigue suas angústias de queda, e lhe permita restabelecer a continuidade com os elementos da vivência prénatal, e a interiorização de uma pele que manterá ligadas juntas as diferentes partes de sua personalidade" (Bick, 1968).

Os trabalhos de G. Haag (1985) trouxeram novas compreensões sobre as primeiras etapas integrativas percorridas pelo bebê. A partir da constituição da "primeira pele" (E. Bick, D. Anzieu) o bebê precisará reunir os dados esparsos de sua experiência sensorial: junção mão-boca, depois junção do hemicorpo direito e esquerdo em torno de uma linha central de divisão vertical, reunião da parte de cima e de baixo do corpo em torno do eixo de divisão horizontal. Para Haag essas primeiras representações de junções corporais simbolizam os laços estabelecidos pela criança com os objetos e também com partes dela mesma. Esse considerável trabalho psíquico só é possível se ele for sustentado pela solidez e pela fiabilidade da atenção do ambiente, especialmente da mãe. 
Nessa mesma linha, A. Konicheckis trata da importância do movimento da criança, afirmando que "o movimento corporal se expressa como um fio que liga as excitações esparsas e difusas”. (Konicheckis, 2008, p. 49). Assim, a identificação aos seus próprios movimentos favorece os primeiros sentimentos identitários da criança, de certa forma o movimento comportaria o berço da representação do objeto. As diversas expressões da sensorialidade, por meio de pré-simbolizações corporais, confirmam e aprofundam o postulado de Freud de que "o Eu é antes de tudo um Eu corporal, ele não é somente um ser de superfície, mas é ele-mesmo a projeção de uma superfície” (Freud, 1923, p. 270).

A percepção do movimento e da ritmicidade interna vai permitir ao bebê articular suas próprias atividades e movimentos ao ritmo de sua mãe, ou daquele com o qual ele se encontra em relação. Trata-se nesse ajustamento recíproco de uma criação rítmica a dois, cada díade terá seu ritmo próprio, seu estilo temporal. As situações de cuidado corporal, de alimentação, são o protótipo disso: a articulação profunda dos ritmos do bebê e da mãe determina uma dança e uma música que acompanham o texto das palavras.

G. Haag (1986), ao estudar a estrutura rítmica do primeiro continente, a mãe, no prolongamento de concepções de Meltzer e Tustin, mostrou a importância dessas primeiras articulações da interpenetração dos olhares, dos ritmos e dos corpos como experiências para o bebê se sentir contido nesse envelope primário, condição para a construção do psiquismo. Essa interpenetração rítmica realiza uma relação onde cada aspecto de um é recebido e contido pelo outro numa relação de holding psíquico: o que G. Haag chama de "teatro das mãos" (2003) sendo uma forma proto-simbólica dessa experiência.

Essas várias concepções buscam descrever como se constrói o pensamento e a atividade psíquica do bebê no seu próprio corpo: gestos, mímicas, movimentos do bebê sendo ao mesmo tempo indicativos e construtivos da própria atividade psíquica. A observação nos mostra que, nas origens, tudo se passa no corpo e na relação. O corpo do bebê apresenta-se como o teatro privilegiado no qual a experiência, a expressão e a elaboração de seu vivido na relação com o outro se dá, construindo as passagens entre o nível sensitivo-sensorial até a futura simbolização do objeto ausente. 
Assim uma das necessidades básicas do bebê é a de ser contido em sua vida psíquica. A partir daí, ele vai descobrir a alteridade e desenvolver a capacidade de simbolizar as experiências, o que pressupõe poder lidar com a experiência da ausência do objeto. É importante lembrar que o objeto continente é interativo - a continência se dá no jogo relacional, entre as capacidades perceptivas do bebê e a capacidade materna de sintonia afetiva.

Tudo isso indica que o trabalho psíquico do outro é central para a maneira como a criança vai conseguir, ou não, constituir seus processos de subjetivação e de simbolização. E o "outro-sujeito" só se torna um objeto para o bebê porque este vai ter intenções em relação a ele, mas, para que isso ocorra, o "outro-sujeito" também deve ter intenções e intenções interpretativas, em relação ao bebê.

Esses vários estudos apontam para a função do objeto, não somente em relação à sua alternância entre presença e ausência, mas também na qualidade de sua presença, o que nos levará a considerar os processos de maternalidade e as dimensões psíquicas da parentalidade. 
Os processos de maternalidade e a ambivalência materna

O processo de tornar-se pai ou mãe corresponde a um longo percurso atravessando a infância, a adolescência e a idade adulta, enraizado no contexto da história geracional de cada um e no ambiente social e cultural específico. As pesquisas recentes mostram o quanto os cenários psíquicos da mãe durante a gestação organizarão, em parte, as inter-relações ulteriores com o bebê após o nascimento.

\section{1}

\section{Os processos de maternalidade}

O cenário psíquico da gestação envolve o devaneio materno em torno da criança imaginada, devaneio que constitui um espaço de antecipação da criança, a construção do bebê imaginado, e que implica para a mãe correr o risco de criar, pré-investir o bebê, através de uma representação antecipadora, descrita em parte por Piera Aulagnier em seu conceito de "Eu-antecipado" (Aulagnier, 1999).

A fantasia da criança imaginada é composta, em três registros, pelo bebê imaginário - enraizado no pré-consciente, é o resultado do desejo de gravidez; pelo bebê fantasmático - inconsciente, é o bebê dos conflitos infantis inconscientes e dos desejos de maternidade incestuosos, objeto de uma dívida simbólica reatualizada pela transparência psíquica da gravidez (Bydlowski, 1998); e pelo bebê mítico - que reflete as referências culturais e da mídia, implicadas nas expectativas e na educação da criança, segundo as diferenciações propostas por Lebovici (1994).

A noção de maternalidade foi proposta por P.C. Racamier (1961) para descrever as modificações psico-afetivas na mulher durante a maternidade. Ele cunhou o termo 'maternalidade' para descrever o estado muito particular da mulher grávida, compreendido como uma crise de identidade, estado que Racamier chegou a aproximar de algumas modalidades psicóticas de pacientes psiquiátricas acompanhadas por ele. O termo define "o conjunto de processos 
psico-afetivos que se desenvolvem e se integram na mulher durante a maternidade" (Racamier, 1961, p. 532). Suas proposições se aproximaram na época dos trabalhos de Bibring e Benedek, psicanalistas anglo-saxões, que consideraram que a gravidez era uma fase de remanejamentos identificatórios comparável a uma crise de identidade. Racamier insiste sobre o papel da identificação da mãe à avó materna e descreve um processo que conduz a mãe progressivamente do narcisismo na direção da objetalidade. Segundo ele, tornarse mãe exige em especial um novo arranjo dos laços com sua própria mãe, envolvendo processos de identificação e de reconciliação.

Já o conceito de parentalidade foi apresentado alguns anos depois, dentro do campo dos estudos da perinatalidade. Segundo Storelu e Morales-Huet (1989), a parentalidade refere-se "ao conjunto das representações, dos afetos e dos comportamentos do sujeito em relação com sua ou com suas crianças, sejam elas já nascidas, em curso de gestação ou não ainda concebidas”. (Storelu e MoralesHuet, 1989, p. 344). Nessa concepção, a parentalidade não deve ser entendida como uma instância da personalidade, mas como uma área de funcionamento dela; nesse sentido, os autores propõe que ela seja aproximada do conceito de relação de objeto, "do qual ela constitui um sub-conjunto particular e essencial: a saber a relação de objeto à criança, seja essa imaginária ou real" (Stoleru et al. 1998, p. 65).

No campo desses estudos, S. Missonier (2003) define a perinatalidade psíquica, inscrita no continuum da construção da parentalidade, como composta pelos processos envolvidos no período compreendido entre o hipotético projeto de ser pai ou mãe e o final do segundo ano de vida da criança. A perinatalidade psíquica vem revelar a interrogação sobre as origens, a diferença de sexos, os percalços da gênese de si e da relação de objeto. Assim, em termos freudianos, dir-se-ia que a perinatalidade psíquica é uma fase de ativação e de revisão dos fantasmas originários - vida intra-uterina, cena originária, castração, sedução.

Missonier (1999) propõe a metáfora de "funcionamento psíquico materno placentário", (Missonier, 1999, p. 312- 313) para enfatizar

...a finalidade funcional da gestação psíquica de continência e de interação com a criança por vir, ao preço de uma renegociação do narcisismo primário materno, do qual o embrião é no início, uma encarnação. Do grau de 
maturação objetal dessa 'criança narcísica' do pré-natal dependerá em grande parte a empatia materna em pós-natal. (MISSONIER, 1999, p. 312.)

A referência à placenta parece ter sido escolhida pelo autor para enfatizar o trabalho de filtragem e de aporte de elementos nutritivos não tóxicos, também presente na função continente da placenta psíquica materna, e que será determinante para a futura relação com a criança, ainda só virtual. Missonier (2004) propõe também o conceito de relação de objeto virtual para descrever esse modo de relação particular entre a mãe e o bebê em seu ventre, processo dinâmico e adaptativo, e que envolve o conjunto dos comportamentos, afetos e representações em torno do embrião e do feto. A relação de objeto virtual representaria assim a matriz de todo o desenrolar posterior da relação de objeto, referindo-se a um processo que vai do investimento narcísico extremo (tendendo a um grau zero do objetal) até a emergência progressiva de um investimento (pré) objetal (Missonier, 2004). A escolha da palavra 'virtual' para qualificar esse modo de relação de objeto, se faz a partir do latim virtualis que significa "só existe em potência”, o virtual opondo-se assim ao atual, e não ao real. Para Missonier, na origem está o virtual, já que, antes de sua concepção, a criança existe, em potência, para seus futuros pais, a força exercida pela atualização dessa virtualidade encontrando-se no centro do processo de parentalidade.

Nos diferentes estudos do período pré-natal, há uma tendência a assimilar essa criança virtual à encarnação do narcisismo materno durante todo o tempo da gravidez, tendência que não leva em conta a dinâmica evolutiva dos processos psíquicos em curso durante esse período, e que tende a validar essa concepção a partir da observação centrada sobre a psicopatologia da gravidez. No entanto, o acompanhamento de mães durante esse período, não tomadas por processos psicopatológicos que fixam uma única modalidade de relação narcísica ao "bebê de dentro", aponta para a construção progressiva, ao longo de um trabalho psíquico contínuo, mesmo se marcado por alternâncias e momentos de crise, construção preparatória e antecipatória do reconhecimento potencial da alteridade do bebê. Assim, Missonier (2004) propõe pensar que esse trabalho de preparação da relação objetal corresponde ao que chama de relação de objeto virtual.

Considerada então por vários autores como uma crise existencial potencialmente maturativa, a experiência da primeira maternidade acarreta para a 
mulher profundos remanejamentos psíquicos, principalmente no registro das identificações, e um retorno por vezes perturbador às suas relações primordiais com os ascendentes, que terão influências marcantes sobre suas relações com o filho que virá.

M. Bydlowsky (2002) considera que a maioria das mulheres atravessa um período de grande vulnerabilidade psíquica por ocasião do nascimento de um filho, especialmente em se tratando do primeiro filho, e que essa fase vai desde a gravidez até os primeiros meses do bebê. Os processos internos que se instalam durante a gestação são as premissas da relação de objeto com o recém-nascido. Depois do nascimento, a criação do campo intersubjetivo entre a mãe e seu bebê se funda sobre as interações fantasmáticas e comportamentais entre ambos, e sabemos que esses movimentos pré e pós-natais estarão na base da construção psíquica do bebê. As alterações profundas que se dão na futura mãe, preparando-a para seu novo papel e para seu encontro com o bebê real, mostram o quanto seus processos serão determinantes para o estabelecimento dessa nova relação, com efeitos marcantes sobre os processos de subjetivação da criança.

Mesmo considerando que o nascimento é uma passagem marcante de um estado a um outro, uma modificação radical, ela o é em relação à existência que já está ali, elaborada ao longo dos meses de gestação, tanto para a mãe, como para a criança, seu pai, a família. Mas entre a passagem de uma continência interna para uma continência externa, quando do nascimento, há, para cada gestante, um ponto de equilíbrio que se situa entre a fantasia materna antecipatória e estruturante e esse momento de risco do primeiro encontro com um desconhecido. A maneira como se deram esses processos de construção antecipatória, que envolvem a idealização narcísica da criança por vir, os efeitos do ressurgimento das angústias infantis recalcadas, e a ambivalência fundamental inerente a toda relação com um outro, marcará o encontro com o "bebê de fora", em sua dialética com a representação do "bebê de dentro".

A relação que se estabelecerá entre a mãe e o bebê, no melhor dos casos sob o olhar do pai, será assim fortemente marcada pelos cenários conscientes e inconscientes da gravidez psíquica, para além do corte fundamental humanizante, corporal e psíquico, do nascimento. Não sem antes lembrar que a transparência psíquica (Bydlowski,1998) durante a gravidez, caracterizada pela grande 
permeabilidade às representações inconscientes, permite o afluxo de fantasias e lembranças habitualmente ocultas, e favorece o ressurgimento de conflitos arcaicos da mulher. Assim, podemos considerar que o período pré-natal representa uma verificação das fundações identificatórias da mulher, e, por esse motivo, um momento privilegiado para o ressurgimento dos traumatismos do passado.

M. Bydlowski (2002) define como transparência psíquica essa modalidade particular de funcionamento do psiquismo materno, na qual a eficiência habitual do recalcamento se vê reduzida, permitindo a emergência de conteúdos psíquicos recalcados, relativos a experiências e fantasias infantis. De certa maneira, a força do recalcamento parece também ficar abalada quando se espera uma criança, e ele assim não assegura mais da mesma maneira sua função protetora. Durante a gestação, apresenta-se um funcionamento psíquico

... marcado por um sobre-investimento da história pessoal da mãe e de seus conflitos infantis, com uma plasticidade importante das representações mentais centradas sobre uma inegável polarização narcísica... (BYDLOWSKI \& GOLSE, 2002, p. 217).

Esse estado se desenvolve ao longo dos meses da gestação e atinge um grau de sensibilidade maior durante seu último trimestre. Dessa forma, especialmente durante a segunda metade da gestação, a futura mãe irá voltar-se com prazer para as temáticas autocentradas e inacessíveis para a maior parte das mulheres que estão fora desse período de sua existência. Mas grandes variações podem ser observadas, em função das vivências passadas e da história infantil da mãe. Isso porque a transparência psíquica reaviva, para muitas gestantes, a memória de sua origem. Assim, angústias primitivas, prévias ao aparecimento da linguagem verbal, podem se reapresentar nesse período com uma intensidade e uma atualidade desconcertantes para a mulher.

Quando a futura mãe conheceu na primeira infância a alternância da presença e da ausência dos cuidados maternos vividos num ritmo adequado e tranqüilizante, isso permitiu ao bebê que ela outrora foi construir a experiência de continuidade, o sentimento permanente de existir. O bebê que a gestante atual foi no passado pôde constituir então um bom objeto interno, "fórmula metafórica que designa esse sentimento de confiança em uma continuidade..." (Bydlowski, 2002, p. 209). A gestação é o período da vida no qual o objeto interno toma a figura do 
feto, do objeto virtual (Missonier, 2004), que será receptor dessa projeção de bom objeto interno constituído em sua mãe.

Mas a imagem interior nem sempre é essa, e alguns bebês confrontam-se com a angústia do caos quando recebem cuidados insuficientes, intrusivos ou discordantes, constituindo nesses casos um objeto interno pouco confiável e até mesmo ameaçador. Ao se tornar uma mulher grávida, o bebê de outrora experimentará a intensificação dessa imagem interior insegura. A criança que nascerá, e que recebe as projeções do objeto interno materno, correrá o risco de ser percebida com angústia, inquietude, até terror. Muitas vezes, ao longo da gestação, período durante o qual a vida onírica é intensificada, os sonhos traduzirão esse retorno das angústias passadas. É o que acontece, segundo Bydlowski (2002), no início de algumas gestações quando são feitos pedidos de interrupção de gravidez, porque as angústias primitivas reavivadas ocasionam o medo de um desmoronamento psíquico. Essa é também uma hipótese a ser considerada nos casos de descompensações graves durante a gestação ou no pósparto, como nas psicoses puerperais.

Por outro lado, esse período é também um momento privilegiado durante o qual, graças à transparência psíquica, um trabalho terapêutico profícuo pode se desenvolver, se o clinico puder estabelecer uma aliança terapêutica com o narcisismo materno. Acolhidas pelo terapeuta, as lembranças carregadas de afeto e de angústia tenderão a se dissipar, e o fantasma invasor, ameaçador para a mãe e para o bebê, pode ter reduzida sua carga pulsional perigosa. É por esse motivo que, também com um propósito preventivo, a possibilidade de uma escuta analítica durante a gestação é considerada muito benéfica, tanto para a futura mãe como para a relação que se estabelecerá com o bebê esperado. A gravidez, sendo um período de grande vulnerabilidade psíquica, é também, simultaneamente, um período no qual há grande potencialidade para que se dêem remanejamentos subjetivos importantes.

A escuta clínica de gestantes indica o quanto o estado de gravidez favorece a revivescência do primeiro laço mãe-filha e por duas vias podemos pensar no tempo da gravidez como favorecendo essa revivescência. De um lado, pelas alterações que se apresentam no psiquismo materno durante esse período, em que o enfraquecimento das censuras e das defesas habituais conduz a um 
sobre-investimento da história pessoal e um retorno das vivências infantis, como vimos acima.

Por outro lado, a gravidez, nesse reencontro com a mãe das origens, reativaria essa primeira relação sob a forma de uma identificação com a mãe. É certo que a ternura inicial das primeiras trocas renasce aqui, mas junto com ela são também reativadas as moções hostis. A loucura materna normal traz de volta também antigos ferimentos narcísicos, traumatismos, lutos e a herança transgeracional, tornados mais acessíveis em razão do enfraquecimento do recalque. Abrindo uma janela maior sobre o inconsciente, os percalços da relação mãe-filha são assim desvelados. É como se a filha, tornando-se mãe, revivesse a intensificação de seu laço com a mãe, no sentido contrário da dinâmica de sua evolução psicosexual que a havia conduzido na direção do pai, segundo a compreensão freudiana (Freud, 1924). O investimento narcisista da gravidez, centrado sobre o corpo, contribui também para esse retorno às origens, ao arcaico, à experiência pela mãe do seu próprio vivido como bebê.

Para Bydlowski (1992) é somente por ocasião da primeira gravidez que se encerra o período de adolescência psíquica da menina, e é nessa ocasião que é possível para a mulher, deixando de lado a relação com a mãe rival edipiana da adolescência, reencontrar a mãe da ternura e dos primeiros cuidados. Ela enumera quatro condições para que a maternidade se dê: o laço com a mãe da origem, o desejo de realização fálica, o desejo incestuoso, com a representação da criança desejada do pai, e por fim, o fruto da relação atual com um homem presente na vida da mulher. Para além da equação simbólica da criança como realização de um voto fálico, a força do laço originário com a mãe da fase pré-edipiana é um ingrediente necessário à filiação feminina. É por esse laço que a maternidade poderá inaugurar um reencontro com o objeto perdido e trazer de volta a lembrança de um passado nostálgico.

Por outro lado, o feto, metáfora do objeto interno, apresenta uma dupla valência, narcísica e objetal, e a esse título suscita uma série de lembranças e angústias relativas ao estranho familiar. Com seu duplo status, presente no interior do corpo da mãe e em seu fantasma, mas ausente da realidade visível, o bebê é um objeto eminentemente narcísico, que existe sem existir. Essa peculiar situação do bebê no interior da mãe, ainda parte dela e de seu corpo, mas objeto de projeções 
e de fantasias, favorece uma indistinção entre um e outro, e produz efeitos de fusão e de indiferenciação que podem ser angustiantes para a mulher e favorecem o ressurgimento do sentimento de inquietante estranheza. (Aubert-Godard, 1998).

\section{2}

\section{Narcisismo materno e inclusão do bebê estranho/familiar}

A construção do espaço psíquico materno durante a gestação envolve pelo menos três dimensões: o tempo, o espaço e a identificação, todas elas atravessadas por alterações na composição narcísica da mulher (Aragão, 2011). Com efeito, a duração da gravidez estabelece uma temporalidade que permite à gestante percorrer os processos de transformação em seu psiquismo, paralelamente às mudanças corporais e ao crescimento do bebê em seu ventre. Em outra dimensão, essas mesmas mudanças corporais produzem alterações marcadas no Eu corporal, e deslocam o sentimento de si e o de seu próprio espaço psíquico, que se alteram para conter um outro ser dentro do corpo e dentro da vida. São processos que envolvem alterações no narcisismo materno.

Assim, a gravidez inaugura a experiência de um encontro íntimo da mulher com ela mesma. O embrião configura para a mãe, inicialmente, um estrangeiro, um outro dentro de seu próprio corpo. Aliás, há uma ilustração orgânica dessa relação, que se concretiza em uma das modalidades de patologia da gravidez. Trata-se da repetição de abortos espontâneos provocados pela rejeição do embrião pelo organismo materno, como um objeto estranho, da mesma forma como ocorrem os fenômenos de rejeição de órgãos transplantados. Para que a gravidez prossiga, é preciso que haja uma adaptação imunológica entre o organismo da mãe e o embrião, mas em alguns casos o organismo materno tem dificuldade em diferenciar a gravidez de uma doença, interpretando-a como uma agressão (Soulé \& Soubieux, 2004). A chave do problema está na maneira como o organismo materno interpreta as informações genéticas paternas presentes nas células do embrião. O patrimônio genético da célula fecundada comporta $50 \%$ de herança paterna. O ovo, que logo se transforma em embrião, vai sofrer a ação de um corpo que busca expulsar esse enxerto. Uma parte do ovo fecundado deve secretar as substâncias que se opõem à essa rejeição pelo organismo materno para que a 
gestação possa prosseguir. Se isso não ocorre, há um aborto precoce, que parece ser o caso para 40 a $50 \%$ dos ovos fecundados; esses abortos muito precoces passarão despercebidos. É preciso, que o organismo materno faça a leitura do embrião como uma gravidez, e não como um corpo estrangeiro a ser rejeitado (Soulé \& Soubieux , 2004).

Poderíamos tomar essa patologia como uma metáfora da aceitação ou não pela mãe de um estrangeiro dentro de si, de seu próprio corpo. Esse bebê pode ser percebido como um invasor, ameaçador. Sabemos também que para mães psicóticas o bebê pode nem chegar a ser percebido como existente, nos casos em que a negação da gravidez persiste até o momento do parto (Racamier, 1961).

Por outro lado, o tempo cronológico da gravidez é necessário para permitir a elaboração do bebê como tal, num deslizamento dessa percepção do feto como parte do corpo até se constituir como um "outro" bebê objeto das projeções maternas. Desse modo, a crise psíquica da gravidez poderia ser pensada como uma conseqüência da intrusão no narcisismo da mãe, causada pela introdução desse outro, mesmo que desejado, em seu espaço psíquico. Como dizia uma paciente ao saber que estava grávida, "nunca mais poderei estar só”. Essa fala expressa o temor de uma intrusão definitiva e permanente desse outro em seu campo subjetivo. Talvez a identificação profunda com o bebê, tal como descrita por Winnicott (1956) no estado de preocupação materna primária seja a única maneira da qual a mãe dispõe para resolver esse paradoxo, de perder seu isolamento narcísico pela maternidade e ao mesmo tempo criar outro ser dentro de si. Assim, fusionando-se inicialmente com seu bebê ela pode encontrar um compromisso para a ruptura radical do seu narcisismo.

Cramer (1999) afirma que as mudanças durante a gravidez podem corresponder à experiência, pela mãe, de se sentir "habitada" por um de seus pais, ou por um aspecto deles, experiência que tanto pode ser bem-vinda como assustadora. De certo modo, tornar-se mãe é reencontrar sua própria mãe. Mais ainda, a gestação seria o tempo necessário para aceitar essa nova situação que envolve ligar-se para o resto da vida com um desconhecido, fonte de angústia, como o vazio. Trata-se, então, de realizar o trabalho de transformar esse estrangeiro em familiar. Durante a gravidez, a criança tem um duplo status, ao mesmo tempo presente no interior do corpo da mãe e em seus pensamentos 
conscientes e inconscientes, mas ausente da realidade, só podendo ser objeto das interações fantasmáticas, onde estão em jogo essencialmente os conteúdos psíquicos da mãe em torno desse objeto ainda eminentemente narcísico que é o bebê, que existe sem existir.

Também há na gravidez uma alteração fundamental na referência de si mesma. A alteração corporal, induzindo necessariamente a uma mudança na imagem do corpo, afeta a representação narcísica da mulher. O limite corporal se modifica, a unidade da representação de si é deslocada para permitir a representação do corpo próprio que vai englobar progressivamente um outro corpo. As mudanças no invólucro corporal e no imaginário representam uma ameaça à construção narcísica. E não há como impedir a alteração que se processa inexoravelmente, a não ser por uma interrupção da própria gravidez. Essa é uma hipótese a ser considerada nas ocorrências de partos prematuros ou de abortos espontâneos repetitivos.

Toda essa modificação supõe a necessidade de o ser da mulher poder aceitar englobar um outro. Diríamos que na dinâmica ambivalente que se processa da mãe para o bebê, parece haver uma oscilação entre um "narcisismo englobante", correspondente à experiência de plenitude em que a mulher se vive completa com seu bebê no ventre, de tal modo que o bebê está incluído em seu próprio narcisismo. E, em contraponto, poderíamos pensar num "narcisismo excludente", quando ela se percebe invadida por um outro, estrangeiro dentro de si, de quem irá livrar-se no parto. O jogo entre a inclusão e a exclusão do bebê, no espaço psíquico da mãe, poderá ser um dos eixos de determinação do investimento dessa criança e do modo como se processarão as passagens dos conteúdos maternos para o psiquismo incipiente do bebê (Aragão, 2007).

No trabalho psíquico materno que consiste em transformar o estrangeiro em familiar é necessário também que a mãe construa antecipadamente o Eu do bebê, na espera desse encontro, imprevisível e eventualmente perturbador. É o que Piera Aulagnier chama de construção do "Eu (je) antecipado", primeiro capítulo da história do infans a vir. Em seu texto "Nascimento de um corpo, origem de uma história” (1999), ela pergunta:

... o que representa o corpo do infans para esta mãe suposta esperá-lo para acolhê-lo?...Aquele que provaria a ela a realização do seu desejo de ser mãe? A última elaboração do objeto de um longo sonho começado na sua própria 
infância? Ela encontra um corpo, fonte de um "risco" relacional (...) encontro que vai exigir uma reorganização da sua própria economia psíquica, que deverá beneficiar esse corpo do investimento do qual gozava até então o único representante psíquico que o tinha precedido... (AULAGNIER, 1999, p. 33)

A esse representante psíquico Aulagnier (1999) chama de "Eu (je) antecipado". Para que se dê a passagem do corpo somático, do corpo sensorial, para o corpo relacional, é preciso uma "historicização" da vida somática, o que, para a autora, exige um biógrafo que possa ligar o evento somático a um destino psíquico. Assim,

... uma primeira versão construída e aguardada na psique maternal acolhe esse corpo para unir-se a ele. Faz sempre parte deste "Eu antecipado" ao qual se dirige o discurso maternal, a imagem do corpo da criança que era esperada (AULAGNIER, 1999, p. 21).

O "Eu antecipado" insere a criança num sistema de parentesco, e sua imagem corporal porta em si a marca do desejo materno. Piera Aulagnier afirma como condição para a preservação da vida psíquica - e certamente para sua própria construção - a existência de um meio ambiente psíquico que respeite exigências tão incontornáveis como são aquelas necessárias para a preservação da vida somática. Isso exige da mãe que organize e modifique seu próprio espaço psíquico para fazer face a essas novas exigências.

A antecipação, fundamental como uma das funções maternas, traz em si a dimensão do tempo. Podemos pensar no tempo da gestação como representando um intervalo psíquico para a mulher durante o qual ela fica suspensa no tempo do outro que está se criando, o bebê. E nesse "tempo-entre" as três dimensões se apresentariam assim: o passado, que ressurge como fantasma, o presente como um tempo em suspenso, e o futuro, tempo marcado pelas projeções, desejos e temores. Desse modo, o tempo da gestação fica caracterizado como um tempo intermediário - entre os fantasmas e desejos do passado e as projeções do futuro (Aragão, 2011).

Como dinâmicas psíquicas fundamentais, influenciando todo o rumo desse processo de maternalização da mulher, encontram-se os percalços da história edípica e também os percalços da relação da menina com a mãe dos primeiros tempos. Pensamos que o que está em jogo é a experiência de perda, o luto em relação a esse primeiro objeto de amor - por decepção, por rivalidade - e a 
maneira como isso se reapresenta na gestação, pois aqui se trata, para a mulher, de fazer apelo no interior de si a esse registro arcaico do objeto materno original, para beber nessa fonte a base para a construção de sua própria maternalidade.

O reconhecimento da força do laço mãe-filha leva-nos a nos servir do modelo melancólico do funcionamento psíquico para a compreensão da dinâmica psíquica durante a gravidez, como também propõe Lina Balestrière (2003) em seu texto "Entre mãe e filha: histeria ou melancolia?" Até então, temos usado o modelo da histeria, base da primeira tópica do aparelho psíquico, e situado sob o angulo do desejo e do recalcamento, para descrever os mecanismos em jogo nas questões da feminilidade e da maternidade. No entanto, o laço inicial da menina com a mãe envolve a incorporação, a identificação, e o trabalho de luto para dele se desligar. Por outro lado, o bebê sendo para a mãe um objeto investido narcisicamente, o modelo melancólico se faz muito útil para pensar sobre as primeiras relações objetais que se estabelecerão entre mãe e bebê.

O modelo histérico do funcionamento mental, na fundação da própria psicanálise, refere-se às noções de desejo, fantasma, inconsciente, recalcamento. A esse título, ele é de grande utilidade para pensar sobre a problemática do desejo de ter um filho, suas variações e seus entraves. Mas chega um momento em que Freud propõe um outro modelo metapsicológico, que será o fundador da segunda tópica, e isso para dar conta de impasses clínicos, entre os quais a reação terapêutica negativa e a força dos sentimentos inconscientes de culpabilidade.

...Aqui não se trata mais de desejo, mas de perda; mais de recalcamento, mas de introjeção, incorporação, identificação; mais de conflitos entre o eu e seus objetos sexuais, mas no interior do eu ele mesmo, doravante dividido em eu e supereu. (BALESTRIÈRE, 2003, p. 88).

Ao oferecer uma descrição do processo de deslizamento do registro do ter para o ser, o modelo melancólico é extremamente útil justamente para pensar sobre a gestação, onde esses dois registros são confundidos, na confusão identificatória inicial da mãe com seu bebê, até que ela possa pensá-lo, no melhor dos casos, como um outro, destacado e diferente dela mesma. Pensar nesses termos nos permite colocar a questão do luto, do processo pelo qual um objeto pode ser deixado, e do destino desse objeto, ou quando ele é incorporado eventualmente ao eu, alterando-o. O bebê, no ventre materno, começa incorporado 
para ir progressivamente se destacando, se desligando, na construção de um lugar próprio a ele dentro do espaço do psiquismo materno.

Além disso, o cenário do nascimento configura sempre a experiência da perda de um objeto, o feto, objeto ainda virtual, meio-eu, meio-outro, situado num entre dois do investimento narcisico e do investimento objetal, objeto que pode ser considerado como potencialmente melancólico, já que seu investimento se deu sob a égide do narcisismo. Mas, lembra-nos Balestrière, referindo-se à Freud, em "O ego e o $i d "$ "... "as coisas são ainda mais complexas, pois o eu ele mesmo é um 'precipitado de investimentos de objetos abandonados"' (Balestrière, 2003, p. $88)$.

E a interrogação que podemos propor concerne, no caso da gravidez, o destino do "precipitado de objetos abandonados" da mãe, e a maneira como tais objetos farão marca nesse corpo nascente do bebê, ainda tão parte dela mesma e construído, inevitavelmente, a partir de seu próprio narcisismo. Assim, além de projetar sobre o bebê seu próprio narcisismo infantil, a mãe projeta também, a sua revelia, partes infantis dela mesma ou partes das imagos parentais negativas, conflituais. É o que Palácio-Espasa e J. Manzano, (1999) nomeiam como a sombra de si dos pais projetada sobre a criança e a sombra dos objetos dos pais projetada sobre a criança.

O bebê representa uma superfície privilegiada para a recepção desse tipo de projeções parentais, necessárias de todo o modo para sua própria constituição. No caso do bebê menina, há uma facilitação dessa passagem entre mãe e bebê, já que estamos no registro do semelhante, do idêntico. Dois movimentos maternos são possíveis nessa configuração: a identificação do bebê menina com a avó materna, em seus aspectos positivos e negativos, com uma contra-identificação da mãe à menina que ela mesma foi; ou então a identificação do bebê à sua própria imagem infantil, com uma contra-identificação à sua própria mãe. Outros arranjos são também possíveis, e vemos como, ao longo do desenrolar da gravidez, eles podem flutuar e se intercambiar, o que dá uma melhor perspectiva ao trabalho de constituição do bebê enquanto tal, do que quando nos confrontamos com projeções e identificações fixadas numa só modalidade (Palácio-Espasa \& J. Manzano, 1999). 
A sombra das primeiras relações com a mãe reapresenta-se, muitas vezes, quando a menina, agora mulher, prepara-se para ser mãe ao seu turno. Sombra que, segundo Freud, resta inacessível, tão violento é o recalcamento que atinge essa etapa da vida. (Freud, 1931). Mas em razão das particularidades da experiência da gravidez, em que a facilitação da emergência dos guardados infantis abre portas e janelas internas, permitindo ir ao encontro de cenários inesperados,

...as sombras do passado retornam e se inscrevem nessa intimidade tão preciosa para o bebê. Os fantasmas dos pais colorem para o melhor e para o pior a relação com sua nova criança... Os pais terão, desde a aurora da vida de seu bebê, de compor, de negociar incessantemente com seus próprios investimentos internos parentais e com as insatisfações, as faltas dos bebês que eles foram" (PALACIO-ESPASA e MANZANO, 1999, p.185).

O investimento no bebê é assim resultado, em parte, dos restos dos objetos desinvestidos, odiados, enterrados, perdidos, dos restos das antigas relações. Mas também, e aí reside o paradoxo, o bebê se constitui, no imaginário materno, como representante do novo, do que poderá vir reparar, refazer, retomar para melhor aquilo que antes falhou. Bebê esperado para vir obturar as falhas narcisicas parentais, o que estará especialmente em jogo na transmissão da maternalidade de mãe para filha.

No que diz respeito às relações inconscientes de uma filha com sua mãe, inevitavelmente re-atualizadas quando da realização da maternidade pela filha, os laços ambivalentes de amor e de ódio, com seu rastro de sentimentos de culpabilidade, se farão presentes no trabalho de luto pela mulher dessas primeiras relações. Ela precisará se reaproximar dessa mãe primordial, levada a isso ao mesmo tempo pela identificação com o bebê que ela carrega, como também pela identificação com sua própria mãe, para chegar a modificar sua posição subjetiva, nessa passagem da posição filial para a posição materna. Os impasses e os sucessos desse processo marcarão para a mulher a possibilidade de assumir sua função materna junto ao bebê por vir (Palácio-Espasa \& Manzano, 1999).

Em outras palavras, nos processos psíquicos da gestação acontece um duplo movimento, narcisico e objetal, que supõe tanto o surgimento de angústias 
edipianas como de angústias de abandono cujos mecanismos se referem, justamente, ao modelo de compreensão dos processos de luto e melancolia.

Será preciso, à mãe, renunciar à sua posse da mãe pré-edípica como objeto de amor, para se identificar a ela e incorporá-la como referência para sua própria função maternante com o bebê. Isso leva a postular a necessidade do lugar do terceiro - no melhor dos casos presente desde o início na relação mãe-bebê - para permitir o descolamento gradual dessa relação primeira, e a instauração de um espaço entre essas duas mulheres - uma distância mínima necessária que permita à filha constituir-se como uma outra mulher, uma outra mãe que se relaciona com seu bebê, um outro agora.

\section{3}

\section{Ambivalência materna}

O trabalho psíquico dos pais envolve lidar com a ambivalência inevitável no encontro com esse outro, o bebê, mesmo tendo sido ele esperado e desejado. Como sabemos, todo encontro com o outro nos relança em uma situação potencialmente traumática, na medida em que representa uma efração ao narcisismo, como desenvolvido por A. Green com a noção do "objeto-trauma" (Green, 1988).

O conceito de objeto-trauma foi apresentado por Green (1988) em seu estudo sobre a angústia e o narcisismo, ao tratar das relações entre o narcisismo e o objeto. $\mathrm{O}$ autor propõe a hipótese de que o objeto, enquanto objeto da pulsão, é necessariamente objeto-trauma, pois representa uma ameaça para o Eu, "à medida que força o Eu a modificar seu regime por sua simples existência" (Green, 1988, p. 154).

...Nesta ótica, o objeto que, no entanto, é originalmente a meta das satisfações do Isso, é, de fato, para o Eu, de certa forma, sempre uma causa de desequilíbrio - em suma, um trauma. Se é verdade que o Eu aspira à unificação e que esta unificação interna estende-se para a unificação com o objeto, a reunião total com o objeto obriga o Eu a perder sua organização.... O objeto-trauma (para o narcisismo) leva-nos então a considerar o Eu não somente como o sitio dos efeitos do trauma, mas também como o das reações contra esta dependência em relação ao objeto, reações que constituem uma parte importante das defesas do Eu, não contra a angústia, mas contra o objeto cujas variações independentes suscitam a angústia (GREEN, 1988, p. 151-152). 
E Green (1988) afirma, a partir dessas constatações, que o problema central das relações entre o Eu e o objeto é o de seus limites e de sua coexistência. Estamos diante de um paradoxo, para não dizer de um impasse. O Eu precisa do objeto, e esse só existe como tal em razão do Eu que dele necessita, porém há um ponto no qual a coexistência é traumática. Assim, enquanto objeto interno, carregado da energia e da fantasmática pulsionais, ele procura penetrar no Eu desde o interior; por outro lado, enquanto objeto externo à montagem pulsional, ele não está à disposição do Eu, e assim o obriga a buscá-lo, ele não é nem fixo nem permanente, sendo aleatório no tempo e no espaço. Com suas mudanças, força o Eu a um trabalho constante de ajustamento. E, mais ainda, o objeto tem seus desejos próprios, que coincidem ou não com os desejos do Eu. Além disso, há as dimensões quantitativas do "demais" ou do "não o suficiente", presente ou ausente, afastado, mas não longe demais, enfim, todas as múltiplas dimensões que marcam os encontros e desencontros entre o Eu e o objeto.

Porém, diz Green (1988), o objeto externo também

...tem como função remediar o mal de que é causa. Fator de perturbação, agente do estranho, perturbador da tranqüilidade do $\mathrm{Eu}$, o objeto pode também, é claro, à medida que é um bom objeto, ser utilizado como objeto consolador, apaziguador, 'objeto-portador', no sentido do holding de Winnicott. Este objeto interno, que poderá fazer nascer o objeto transicional, apóia-se no objeto dos cuidados maternos da mãe dita "suficientemente boa", segundo a terminologia de Winnicott. (GREEN, 1988., p. 155-156).

Certamente a gravidez pode ser compreendida como um processo que coloca em cheque a "constante tentativa de preservação da unidade narcísica pelo Eu” (Garcia, 2015, p. 4), em razão da introdução do objeto virtual representado pelo feto no corpo e no espaço psíquico materno. Como afirma Garcia, "se é verdade que o Eu aspira à unificação, e que esta unificação interna inclui a unificação com o objeto, a possibilidade de reunião total com o objeto, no entanto, ameaça o Eu a perder sua organização" (Garcia, loc.cit.). Nesse sentido, a modelização de Green do objeto-trauma é pertinente para considerar o trabalho psíquico intenso que a gestante deve desenvolver para encontrar um equilíbrio que preserve a organização do Eu, tendo que, ao mesmo tempo, se ligar a esse outro, o feto, ainda não distinto dela e com o qual ela corre o risco de se confundir, e também constituir um espaço psíquico que torne possível a diferenciação futura entre si e o outro, o bebê. 
Em outra perspectiva, constata-se que a gravidez continua a ser objeto de uma persistente idealização defensiva. Ao lado disso, o bebê, produto dela, é também facilmente visto numa posição idealizada. Quem é então esse bebê, tão próximo e tão distante? Estranho, estrangeiro, com seus comportamentos, seu "eu arcaico" que ao mesmo tempo nos fascina e nos afasta. Mas também familiar, pelo que nos assemelha, pela identidade do humano que o caracteriza e que nos faz reviver nosso próprio "tempo de bebê". Sem esquecer a condição de dependência radical do bebê, que nos impõe uma responsabilidade absoluta, e, portanto um poder de vida e de morte sobre ele. Para algumas mães, esse poder pode ser assustador, insustentável.

Assim, a gestação não é um processo suave; ao contrário, suscita e mobiliza identificações, lembranças e vivências arcaicas, conflituosas e intensas. Pode ser descrita como um jogo de amor e de ódio, de desejo de vida e de morte. Não faltam ocasiões para traumatismos e decepções, mesmo nas gestações ditas normais e desejadas. A ambivalência materna é inerente à gravidez, mas é frequentemente negada, pela própria mãe e pelos que a cercam, como também pela cultura, sendo objeto de um recalcamento ativo e persistente. A reação da mulher à situação da gravidez depende do que ela espera dela, e em especial se o que a move é o desejo do filho, distinto do desejo de gravidez, ligado ao desejo de preencher um vazio ou de provar sua potência. A ambivalência em relação ao feto pode nesse caso ser fortemente exacerbada.

Os trabalhos de F. Sirol (2004) sobre o ódio ao feto descrito nas circunstâncias extremas de diagnósticos pré-natais de risco ou de patologias do feto oferecem uma base de reflexão e de extrapolação para além desses casos patológicos. O ódio ao feto releva da violência fundamental, assim nomeada por Bergeret (1984), ligada ao instinto de auto-conservação da mãe. E Winnicott (1947), de maneira um pouco surpreendente, reuniu 23 razões para a mãe odiar seu bebê. Esse ódio, que fica latente, encriptado, pode se manifestar após o nascimento, reaparecendo por ocasião dos distúrbios das relações precoces e da expressão de patologias psicosomáticas no bebê, e como já foi apontado acima, cabe perguntar se os fantasmas destrutivos da mãe não têm uma influência sobre o desenvolvimento psicosomático do feto e do bebê. 
M. Soulé (1992) foi pioneiro nesse interesse pela vida psíquica do feto, e pelas relações imaginárias entre gestante e feto. Ele considerava que há uma luta biológica entre a mãe e o feto que se situa num equilíbrio entre a violência fundamental e a tolerância biológica desse enxerto que constitui o embrião e o feto no corpo da mãe, equilíbrio controlado pela função reguladora e mediadora da placenta. Esses conflitos da vida uterina podem ressurgir e se manifestar em alguns quadros de doenças imunológicas e nas patologias alérgicas.

Além disso, o narcisismo da mãe sofre por ter de investir totalmente a criança que a impede de viver por ela mesma, obriga-a a renunciar a uma parte de sua vida de mulher. Se uma mãe está pronta para dar a vida por sua criança, ela deve também contra-investir a violência pulsional de sua própria autoconservação e sua vontade de fazer desaparecer essa criança tirânica, para poder então experimentar a ternura pelo filho.

Winnicott (1947) explicitará o ódio da mãe por seu bebê, no texto clássico "O ódio na contratransferência” assim :

...no entanto, a mãe odeia seu bebê desde o começo. Eu acho que Freud julgava possível que uma mãe só tivesse ... amor por seu menino, mas podemos duvidar disso. Nós conhecemos o amor materno, e apreciamos sua realidade e seu poder. Permitam-me dar algumas das razões pelas quais uma mãe odeia sua criança, mesmo um menino... É preciso que uma mãe possa odiar sua criança sem nada poder fazer. Ela não pode expressar-lhe seu ódio... A sentimentalidade é inútil para os pais, porque ela nega o ódio e a sentimentalidade de uma mãe não vale nada do ponto de vista da criança. (WINNICOTT, 1947, p. 56)

Além de explicitar o ódio, Winnicott afirma sua inevitabilidade. Se retomarmos, de um lado, a noção da continuidade entre o processo psíquico da maternalidade entre os períodos pré e pós natal, e a acepção freudiana do ódio, determinado pela existência mesma do objeto, constataremos, que o ódio descrito por Winnicott se enraíza no ódio inevitável da mãe dirigido ao embrião e ao feto, objeto estranho, invasor de seu espaço narcísico e corporal. Entre realidade e fantasma, podemos considerar o feto como um operador simbólico, que nessa condição pode vir a ser alvo de qualquer representação que tenha sido fonte de ódio no curso do desenvolvimento infantil da mãe, figurando nessa cadeia simbólica cuja emergência é facilitada pelo estado de transparência psíquica 
materna. Cada gravidez impõe à mulher, sem que ela o saiba, uma volta às etapas infantis de seu desenvolvimento que foram fontes de ódio e de ambivalência.

Nesse sentido, a futura mãe fica confrontada a um duplo movimento identificatório: de um lado a busca imaginária da criança que ela mesma foi, de outro lado, constituir uma identidade parental, que se relaciona com a mãe que ela teve, ou que ela gostaria de ter tido. Essas identificações relançam sobre a cena psíquica os cenários de fusão, de separação e de diferenciação. Todo esse trabalho psíquico faz parte do investimento do feto, e ajuda a mulher a tornar-se mãe.

A existência do feto desperta ou atualiza o conflito psíquico decorrente da ambivalência. Mas é importante ressaltar que os sentimentos sádicos, hostis e destrutivos que a futura mãe consegue reduzir ou conter participam da essência do processo de maternalidade, da composição do estado da preocupação materna primária, tal como descrito e conceitualizado por Winnicott (1956):

...A minha tese é que, durante a fase mais precoce, lidamos com um estado muito especial da mãe, uma condição psicológica que merece um nome, tal como Preocupação Materna Primária. ....Esta condição gradualmente se desenvolve e se torna um estado de sensibilidade aumentada durante, e especialmente, no final da gravidez; ela continua por algumas semanas após o nascimento da criança. As mães não se lembram facilmente dessa condição. Eu iria mais além, e diria que a recordação que a mãe tem deste estado tende a ser recalcada (WINNICOTT, 1956, p. 170).

Winnicott (1956) compara esse estado materno a um estado de dissociação, a uma perturbação profunda comparável a um episódio esquizóide, durante o qual uma parte da personalidade toma temporariamente o controle. Porém ele ressalta que é preciso que a mãe esteja saudável para poder atingir esse estado de hipersensibilidade, para o qual Winnicott usa, propositadamente, o termo 'doença', e para sair dele, quando o bebê a liberar.

Durante a gravidez, a presença do feto transforma o corpo da mulher, e obriga-a a renúncias para as quais ela não estava preparada, além de levá-la a fazer o luto de sua vida antes da maternidade para dar um lugar ao bebê. Além disso, sua presença coloca-a numa posição de passividade contra a qual ela nada pode fazer. E sua existência obriga a mulher a desenvolver um trabalho psíquico complexo, ao mesmo tempo narcísico e objetal, que desperta ou reatualiza o conflito devido à ambivalência, que consiste em ter de manter e destruir, ao mesmo tempo, o objeto amado. Será uma luta contra a emergência de sentimentos 
e de pensamentos hostis e destrutivos, luta que permitirá à mulher organizar a experiência da gravidez e torná-la suportável.

No entanto, esses sentimentos violentos profundamente guardados no inconsciente, podem intensificar-se em circunstâncias desfavoráveis, e conduzir a riscos graves, tanto para o bebê como para a mãe. Compreende-lo pode ajudar a prevenir as descompensações depressivas, as perturbações na relação mãe-bebê e seus riscos para a psicopatologia do bebê, assim como as descompensações mais graves, de tipo psicótico.

De que modo o ódio da mãe pelo feto, estranho invasor de seu espaço psíquico, portanto inevitavelmente objeto de ambivalência, se faz presente na relação mãe-bebê? Se o objeto se faz conhecer pelo ódio, em decorrência da experiência de invasão do espaço do $\mathrm{Eu}$, ou então a partir da vivência de sua perda, como isso se transporta da relação de objeto virtual, com o "bebê de dentro", para a relação com o "bebê de fora", o bebê da realidade?

Em suma, o feto lembra à mulher que ela está tomada em um processo que lhe escapa, processo de reprodução do outro, do mesmo, no qual sua individualidade está negada. Mas sua capacidade de manter a criança viva, a solicitude, a capacidade de comunicar-se com ela, de colocar em prática tudo o que ela precisa, e principalmente a capacidade de se transformar para seguir esse processo são contra-investimentos fundamentais nesse processo de maternalidade. 


\section{O ritmo e a complexidade dos jogos simbolizantes}

Será tratada aqui a importância do ritmo nos processos iniciais de subjetivação, tal como ela pode ser compreendida na relação inicial entre o infante e seu objeto primário, buscando delinear uma articulação entre o registro do ritmo e a qualidade da presença/ausência materna em sua relação com o bebê.

R. Prat (2007) propõe uma hipótese central sobre a construção do psiquismo considerando os elementos mais antigos da percepção que permitiriam ao sujeito, desde a vida intra-uterina, compor uma informação sobre o mundo em termos de ritmicidade. Seria no início a ritmicidade do contato da pele, e que rapidamente se apresentaria nas demais modalidades sensoriais, até permitir alargar as características do vínculo, em relação à alternância presença/ausência. Apoiando-se sobre os dados da embriologia, a autora sugere que o início da vida psíquica, indissociável da vida somática, é "marcado pela alternância rítmica das sensações e as primeiras sensações são as do toque." (Prat, 2007, p. 81, itálicos da autora).

O problema para o bebê após o nascimento será o de restabelecer a continuidade, de reencontrar um suporte, um contato. As primeiras relações estabelecidas pelo bebê se dão no nível corporal, por meio dos cuidados, do toque, do modo de ser sustentado, - compondo todas as notas e marcas do encontro do bebê com o outro, com o qual e pelo qual ele se constitui, encontro que só se dá por meio de suas capacidades de percepção e de sensação, de seu aparelho sensório-motor.

Para além do ritmo, tomado como um parâmetro fundamental do jogo intersubjetivo sustentando os processos iniciais de subjetivação, outros elementos ligados ao modo de presença do objeto primordial precisam ser levados em conta, e envolvem a maneira como o objeto se apresenta ao sujeito facilitando ou dificultando seus processos primários de simbolização, e a maneira como ele aceita, ou não, deixar lugar no psiquismo da criança para a inscrição de objetos substitutos. 


\section{1}

\section{O ritmo e os processos de subjetivação}

Nos tempos iniciais a subjetividade do bebê não é unificada. Como Myriam David (1997), pode-se dizer que a criança vive numa nebulosa psíquica, ou, como Marcelli (2000/2006), que ela lida inicialmente com aglomerados de experiências que irão pouco a pouco se integrar, compondo o primeiro Eu rudimentar. Essas experiências arcaicas não estão ligadas umas às outras, pela falta da integração. São experiências subjetivas arcaicas vividas no corpo, experimentadas como sensações e movimentos, o que se expressa quando falamos de processos sensório-motores. Para Roussillon (2010), essas experiências são vividas fora do tempo cronológico, e, tenderiam a ser sem começo e sem fim, sobretudo se estiverem acompanhadas de desprazer. Porém, quando forem experiências de prazer tenderiam a se inscrever como formas rítmicas elementares, que as organizam numa temporalidade rudimentar.

Freud (1923) já afirmava que o eu é primeiramente um eu corporal, e que o reconhecimento do mundo pela criança se dá, inicialmente, através e pelo corpo, construindo a partir dele seu mundo interno, na relação com os objetos externos, que pouco a pouco irão povoar e constituir seu psiquismo. Apontava assim como os primeiros registros da experiência subjetiva se dão de forma complexa, enigmática, multi-sensorial, misturando a parte do sujeito e a parte do outro, excitação interna e externa, sensação e precursores de representação. Para D. Stern (1992/2004), a constituição do psiquismo do bebê se dá por meio de um processo de co-construção sensório perceptual entre o bebê e seus adultos primordiais. Trata-se do corpo relacional que afeta e é afetado pelo outro. Assim, o corpo do bebê pode ser considerado não só como via de acesso aos seus processos de constituição psíquica, mas para além disso, ser entendido como o lugar de vida e de expressão de seus impulsos básicos e de suas relações primordiais.

Vários são os enfoques que buscam determinar os fatores que favorecem, ou, ao contrário, perturbam ou impedem os processos de diferenciação e subjetivação. Entre esses fatores, o destaque dado à importância do ritmo entre mãe e criança permitiu avançar na compreensão dos processos sutis e quase 
imperceptíveis que se passam entre os dois parceiros dessa relação primeira. A noção de ritmo mostra-se atualmente central no campo das interações precoces e da instauração do aparelho psíquico. Para B. Golse "é o ritmo das interações que abre simultaneamente sobre os registros do afeto e da representação, como uma espécie de placa giratória da ontogênese da psique" (Golse, 2006, p. 91).

Assim, estabelecendo conexões entre os ritmos percebidos pelo feto na vida intra-uterina e os ritmos das interações corporais e vocais com a mãe após o nascimento, desenham-se hipóteses para compreender essas bases iniciais das interações primárias, que servirão ao bebê como referências constitutivas em sua integração das experiências sensoriais e relacionais. Lembramos que o bebê ao nascer aborda o mundo já com algumas pré-concepções, ou virtualidades, como formas primeiras em busca de atualização para se tornarem utilizáveis. Essas formas influenciam sua maneira de perceber e de investir o que está no ambiente, seus encontros com os objetos primordiais, suas futuras elaborações e transformações integrativas das experiências.

A construção do vínculo entre mãe e criança pode ser vista como uma história de encontros e desencontros, de harmonias e desarmonias, cujas vicissitudes se desenvolvem em torno de variações, de aproximações e afastamentos, construindo o que se pode descrever, com cada filho, um estilo único e singular de trocas e de interações. Entre as características desse vínculo, o ritmo compartilhado entre os dois parceiros, mãe e criança, apresenta-se como um elemento fundamental.

V. Guerra (2011) propõe o entendimento do ritmo em três perspectivas: primeiro, como "reiteração de uma experiência de forma cíclica e com certo grau de previsibilidade", segundo, como "uma forma de organização temporal da experiência que tem estreita relação com a intensidade", e, por fim como "uma das primeiras formas de inscrição da continuidade psíquica, um núcleo primário de identidade (identidade rítmica)”. (Guerra, 2011, p. 281-282). O autor relaciona assim as dimensões da temporalidade e da maior ou menor intensidade da experiência, o caráter cíclico e previsível da experiência rítmica, e a instalação da continuidade psíquica, representada por uma forma primária de identidade que estaria estreitamente vinculada à experiência de "estar com" outro ser humano. 
Assim, o ritmo próprio e singular seria uma marca identitária primária inscrita para sempre no psiquismo e no corpo, como um traço da identidade do sujeito ao longo de sua vida. O registro e a construção desse ritmo singular passa necessariamente pelo corpo do bebê, em suas múltiplas interações com o corpo, a voz e o olhar do "outro-sujeito" materno. (Roussillon, 2010). O ritmo partilhado entre adulto e criança relaciona-se com as condições para o nascimento psíquico, como a mutualidade e a reciprocidade, e com a assimetria radical que marca essa relação. Seria também, nessa compreensão, o terreno indicativo da harmonia ou da desarmonia desse encontro inicial.

A. Ciccone $(2005,2011)$, tratando das primeiras constituições psíquicas, refere-se às diversas funções do ritmo, dentre as quais destaca o fato de ser base de segurança para o sentimento de continuidade do ser. Ciccone (2011) relaciona o registro do pulsional com o sensorial, o sensível, o perceptivo. São as pulsões que investem as sensações, as percepções sensoriais ou emocionais, e dessa forma desenvolvem-se as competências psíquicas do bebê. Pensamos que pode ser justamente a dimensão rítmica o elemento que proporcionará uma liga de base para as diferentes experiências sensoriais e perceptivas. Por outro lado, o ritmo não pode ser cogitado sem a intervenção, a presença do outro. O ritmo, que para Roussillon (2006), seguindo Freud, é uma característica da pulsão -“o impulso rítmico interno"- se compõe e se desenvolve na música do encontro com o outro. A pulsão representaria a fonte de um ritmo interno gerenciando as modalidades de investimento da realidade externa e, portanto as modalidades da percepção sensorial. Mas o essencial se dá no encontro entre a ritmicidade interna do sujeito e a ritmicidade do objeto com o qual ele entra em relação. A harmonização dos ritmos de um e do outro é fundamental para o encontro e o contato, visto como parte de um processo dinâmico interativo.

Segundo B. Golse (2006), a pulsionalidade, entendida como a dimensão pulsional do funcionamento corporal e psíquico do sujeito, se expressaria pelo ritmo, que se mostraria assim como "um elemento central na estrutura dos processos de atenção e seria indispensável aos processos de comodalização perceptiva entre mãe e bebê, e portanto à construção da intersubjetividade" (Golse, 2006, p. 262). E essa ritmicidade assim composta teria função fundamental em relação ao sentimento de ser e de continuidade, e ao sentimento 
de segurança interna do bebê que permite sua abertura ao mundo. Poderíamos considerar a harmonização suficiente dos ritmos como uma forma de ritmicidade conjunta que engendra um senso primário de identidade, acompanhado da experiência de continuidade psíquica.

Se pensamos, com Ciccone (2011), que a percepção, a sensorialidade e a pulsionalidade representam parte dos fundamentos da realidade psíquica, o outro fundamento é representado pela inter-subjetividade, que implica o trabalho psíquico do objeto. É sobre ela que se funda a subjetividade, no sentido de apropriação da experiência subjetiva, para a qual, enfatiza ainda Ciccone, é preciso supor a experiência de um compartilhar, e inicialmente de um compartilhar de afetos, de emoções. Essa experiência compartilhada entre adulto e criança é, segundo o autor, "ao mesmo tempo uma das figuras ou uma das cenas da inter-subjetividade e uma das condições de sua constituição" (Ciccone, 2011, p. 83).

Ainda para esse autor (Ciccone, 2015) a ritmicidade no bebê refere-se a três modos de experiência: ela abrange a alternância entre as posições de abertura objetal e de retirada narcísica, as trocas interativas e intersubjetivas, e as experiências de presença/ausência do objeto.

Os movimentos de abertura objetal e retirada narcísica são necessários para a interiorização das experiências. É assim que, após um momento de troca, de contato com o mundo, a retirada permite replicar de si para si mesmo, recriar em si a experiência vivida, permite interiorizar a experiência de contato com o mundo, e nesse espaço compor elementos da subjetividade. É o que ocorre com os ritmos da vigília e do sono, e também com os diferentes níveis de vigilância do bebê. O recém-nascido dorme em torno de 20 horas por dia, passa então a maior parte de seu tempo experimentando uma atividade psíquica interna, onírica. Também, os estudos de interação do bebê mostram com clareza que ele se serve dos seus diferentes níveis de vigilância para iniciar ou interromper uma interação.

Mas uma condição para que as trocas interativas sejam interiorizadas é que elas sejam rítmicas, e que respeitem o ritmo próprio do bebê. Assim, uma interação contínua, permanente, que não tolera o movimento de retirada do bebê, é excessivamente excitante e pode, em conseqüência, produzir na criança um tempo 
de retirada anormalmente prolongado, como uma modalidade defensiva precoce em relação a uma experiência vivida como intrusiva.

As interações pais-bebê compõem uma verdadeira dança, uma coreografia, na qual as sintonias e ajustamentos visam encontrar ou criar o ritmo que sustentará o encontro intersubjetivo, o compartilhar da experiência. As observações de bebê mostram que muitas vezes é a criança que inicia e que conduz a dança. Assim, por exemplo, nas proto-conversações com um bebê, quando a mãe se dirige a ele com uma determinada melodia na voz, ele produz movimentos que acompanham a melodia da voz materna, e, muitas vezes, percebe-se que os movimentos do bebê precedem as variações de entonação da mãe, como se ele fosse um verdadeiro maestro (Trevarthen e Aitken, 1997). Mas para encontrar essa ritmicidade, é importante que seu parceiro o siga, respeite seu ritmo, se adapte ao seu ritmo. Muitas vezes a mãe ou outro parceiro na interação irá introduzir variações que produzem surpresa e jogo, mas essas variações precisam respeitar um limite para serem aceitas pelo bebê sem romper a ritmicidade conjunta.

\section{Presença/ausência, antecipação e ritmo}

Para A. Ciccone (2015) a alternância entre presença e ausência do objeto também deve ser rítmica para permitir ao bebê manter o objeto vivo no interior de si. Como as ausências são inevitáveis, o bebê passa de todo modo por experiências de descontinuidade; a observação mostra que nessas situações ele faz grandes esforços para manter a continuidade. Assim, por exemplo, um bebê quando começa a ser alimentado com a colher, que o faz viver uma experiência de presença/ausência, busca o olhar da mãe, que ele acompanha atentamente, sem se desligar dele. Outro exemplo mostra o bebê, depois do desaparecimento da mãe de seu campo visual, e um reaparecimento rápido dela, recriar com seu corpo as duas partes separadas, juntando e separando as mãos, e/ou juntando e separando os pés, o que Geneviève Haag chama de identificações intracorporais (Haag, 1986, 1997), modo de representação corporal que permite ao bebê integrar e interiorizar suas relações primitivas com o objeto. Esses exemplos são testemunha do trabalho psíquico que o bebê realiza para lidar com a ausência e limitar as 
vivências de separação e de descontinuidade. Se essas vivências são inevitáveis, a perda não pode exceder um determinado tempo, que aumentará progressivamente de acordo com a idade do bebê e sua capacidade crescente de guardar em si o objeto ausente. Isso porque, para além de um determinado tempo, o objeto não sobrevive no espaço psíquico do bebê, levando ao um estado de desespero e de colapso interno, como já havia apontado Winnicott (1971) sobre o caráter traumático da separação, que, se ultrapassa o limite tolerável pelo bebê, pode mergulhá-lo na experiência da agonia, quando então a ausência passa a ser o vazio. Aqui, não se trata mais para o bebê de suportar a ausência, mas de lidar com o vazio.

A ritmicidade dos cuidados e das interações é essencial por proporcionar uma ilusão de permanência, tornando tolerável a descontinuidade. Além disso, ela permite a antecipação, que favorece o nascimento do pensamento. Para Ciccone (2015), o pensamento não nasce da ausência, mas da antecipação.

O trabalho do pensamento permite tolerar a ausência e lidar com a perda. A antecipação permite ao bebê desenvolver a ilusão da criação do objeto. O bebê que pode antecipar - porque a experiência esperada se apresenta de maneira rítmica - desenvolve a ilusão de que ele cria a situação, a experiência, o objeto, contribuindo para a construção da confiança em si, que ajudará a suportar um fracasso, uma experiência infeliz, uma decepção, uma dor. Ele pode antecipar que da próxima vez será melhor (Ciccone, 2015, p. 5).

Essa ritmicidade diz respeito a todas as interações, às sintonias $\mathrm{e}$ harmonizações no vínculo com um bebê. Porém, algumas disritmias são inevitáveis nesse encontro, e elas podem até criar um jogo, um estado de jubilação, de excitação, próprio do brincar (Marcelli 1992, 2000), supondo sempre uma continuidade de base nas trocas. "Em outras palavras, as disritmias temperadas devem se desenrolar sobre um fundo de permanência que garanta a segurança de base" (Ciccone,loc. cit.).

O conceito de Stern de harmonização ou sintonização afetiva descreve um processo que se situa justamente nesse campo da experiência compartilhada e da intersubjetividade. Chamado por Stern de "affectif attunement", a escolha da palavra "attunement" indica a referência musical e aponta para um afinamento ritmado entre a mãe e o bebê. 
Nas palavras de Stern, a harmonização afetiva é

...um ato de inter-subjetividade no qual a mãe responde a uma expressão afetiva do bebê remanejando-a de uma outra forma, e reapresentando-a de volta ao bebê de tal modo que ela mostra a ele que compartilhou sua experiência subjetiva interna (Stern, in Houzel et al, 2000, p. 12-13)

Stern desenvolveu esse conceito para tentar responder a um problema central na relação mãe-bebê: como uma mãe consegue fundar o compartilhar intersubjetivo de uma experiência afetiva expressa pelo bebê? Como fazê-lo sem usar a linguagem verbal, que a criança ainda não compreende? Trata-se para a mãe de comunicar ao bebê que percebeu seu comportamento e que esse teve ressonâncias afetivas para ela. Para superar então essa dificuldade, a mãe vai responder à criança por meio de uma imitação modificada, que deve reproduzir as mesmas propriedades da expressão do bebê, especialmente a intensidade, a cadência no tempo (duração, medida, ritmo) e a forma, respeitando assim uma homologia de estruturas entre sinais e respostas. Freqüentemente a mãe consegue fazê-lo transpondo a manifestação do bebê para uma outra modalidade sensorial, utilizando a capacidade precoce do bebê de transmodalidade, (Stern, 1989) que o faz transferir as informações recebidas por um canal sensitivo-sensorial para um outro canal (visual, tátil, auditivo, etc.). Isto é, o bebê humano tem a possibilidade de extrair de suas sensações tácteis, por exemplo, uma estrutura morfológica que ele identifica depois quando entra em contato com sensações visuais, o que corresponde, de certa forma, a um verdadeiro trabalho de abstração. (Golse, 2006). Podemos supor que o ritmo é que faz ligação nas 'áreas' da transmodalidade, é o que favorece a progressiva integração das várias experiências sensoriais que se apresentam nos poros, orifícios e partes do corpo do bebê.

A sintonização afetiva entre mãe e bebê, ao invés de manter o foco sobre o comportamento externo, desloca a atenção para o interior, para a qualidade do sentimento compartilhado, sendo uma parte central dos processos que constroem, na criança, a experiência da intersubjetividade. A resposta do adulto conforta as bases narcísicas do bebê, informando-o sobre a natureza dos sinais que ele emite, e lhe dá o sentimento de estar sendo empaticamente acompanhado. É assim que o bebê chega a reconhecer o estado emocional da mãe, seu estilo interativo e percebe as mínimas mudanças nesse estilo. O importante é que a estrutura da 
resposta da mãe seja análoga à do bebê, porém levemente diferida no tempo e no ritmo.

A sintonia afetiva pode ser observada a partir do segundo semestre da vida, mas provavelmente ela começa a se construir mais cedo, e seus precursores podem ser identificados por meio da observação das interações mãe-bebê. Essa sintonia pode se desenrolar de diferentes maneiras, que irão marcar o estilo interativo de cada dupla, podendo ser mais unimodais, ou transmodais, mais imediatas ou diferidas, mais atenuadas ou amplificadas. A partir do oitavo ou nono mês esses processos funcionam dentro de uma verdadeira reciprocidade, e ajudam o bebê a distinguir se as modalidades interativas atuais do adulto com o qual ele está em relação combinam ou não com o estilo interativo habitual desse parceiro, que o bebê tem inscrito psiquicamente. Assim, se a mãe se mostra deprimida, sua sintonização afetiva será alterada, tornando-se mais lenta, mais unimodal do que é habitualmente, e o bebê notará essas alterações. Por outro lado, a capacidade do adulto para sintonizar afetivamente com seu bebê depende em parte daquilo que o próprio bebê induz na interação, da parte pessoal do bebê, e do tipo de personalidade do adulto, como também de sua própria história infantil precoce. É por meio de um processo de identificação regressiva ao funcionamento psíquico da criança que o adulto pode encontrar as respostas relacionais adequadas aos sinais que a criança lhe transmite (Golse, 2006).

A partir de um ponto de vista próximo dos autores acima, Daniel Marcelli, (2000) descrevendo a passagem entre o registro da atividade sensorial e perceptiva para a atividade de pensamento simbólico, postula que é o fator 'tempo' o elemento permitindo essa ligação e essa passagem. Seria a repetição, a ritmicidade das experiências, das trocas entre o bebê e sua mãe, que permitiria a ele organizálas num eixo temporal e fazer a ligação entre os diferentes aglomerados de experiências, lançando as bases da função simbólica. Graças à ritmicidade e também à capacidade crescente de atenção do bebê surge nele a capacidade de retardar e de conservar durante um tempo, mesmo mínimo, a informação nova. É o ambiente que mantém essa ritmicidade e essa ritualização, oferecendo uma experiência de permanência e de continuidade, que deve estar presente na relação de cuidado do bebê, como também, apontará Ciccone, de forma análoga, na situação clínica, sobretudo com pacientes graves (Ciccone, 2011). 
Segundo Marcelli (2000/2006), o ritmo, porém, não pode ser confundido com a repetição e a cadência; ambas fazem parte do ritmo, mas ele é bem mais do que isso.

...O ritmo não seria uma simples sucessão, no que ele se diferencia da cadência: o ritmo é essencialmente um liame. Ele liga o que é do registro da continuidade com o que é do registro da suspensão, ruptura, cesura, corte com o outro. No instante em que se dá o corte, o ritmo está na continuidade de antes e na continuidade de depois, mas no instante da continuidade, o ritmo está também na cesura de antes e naquela de depois ( MARCELLI, 2000/2006, p. 129).

O ritmo é então o que liga e religa, através do tempo, a continuidade e o corte, a temporalidade sendo composta não somente por repetições, mas também por surpresas, assim então entre cadência e ruptura de cadência. "A surpresa se constrói em torno da espera, que é a primeira marca do tempo no espírito humano" (Marcelli, 2000/2006, p. 127) Para o autor, a essência do ritmo estaria nessa tensão indefinível entre uma necessidade de regularidade e de repetição, de um lado, e uma espera de surpresa, de espanto, de outro lado. Os bebês são extremamente sensíveis aos ritmos, mas tanto a repetição monótona quanto as mudanças caóticas não lhes fazem bem. Marcelli (2007) postulou a função de "macroritmos" e "microritmos" para a organização do bebê, partindo da hipótese de que uma alternância entre surpresa e repetição é indispensável ao funcionamento psíquico. Assim, ele descreveu as interações relacionadas aos cuidados, que permitem ao bebê desenvolver antecipações que se confirmam em sua rotina e em suas interações com os cuidadores. São os "macroritmos" quotidianos, o despertar, as refeições, as trocas, o passeio, o banho, o deitar, etc., atividades relativamente fixas ao longo dos dias. O bebê pouco a pouco vai perceber os sinais da mãe de que uma ou outra atividade vai acontecer em breve, e ela o indica tanto pelos gestos como pela fala. Essas antecipações confirmadas, segundo Marcelli (2007), dão ao bebê o sentimento de ser o criador de seu ambiente, provendo um sentimento de onipotência. Ligam-se aqui a satisfação das necessidades primárias e o apaziguamento dado pela previsibilidade dos atos. Esse é um tempo repetitivo e circular em torno do qual se desenvolvem as interações de cuidados, e a continuidade narcísica do bebê se apóia sobre a confirmação e a satisfação de suas expectativas, no registro do narcisismo primário. Porém não só de repetições e confirmações se faz um bebê... Marcelli (2000/2006) dedicou-se a descrever e analisar em detalhes as interações lúdicas 
das mães com seus bebês, pelos jogos de cócegas, as brincadeiras de se esconder, as cantigas infantis, e nelas identificou a importância do elemento de surpresa, de inesperado, de 'engano', e de falsas provocações da mãe com sua criança. Muitas vezes nessas brincadeiras nota-se uma mensagem contraditória entre o tom da voz e a expressão do rosto da mãe. Nesses jogos, o bebê hesita entre a surpresa e o riso, e fixa toda a sua atenção nas expressões da mãe. São essas as interações que Marcelli (2007) nomeou como "microritmos", pois são breves e aparentemente inúteis, mas as mães só as realizam quando têm liberdade para brincar assim. São interações lúdicas, sem sentido prático. Seria então a conjunção desses dois tempos, "microritmos" e "macroritmos" que fundamentaria o ritmo no qual o bebê se instala. "Inscrito num "macrorítmo" suficientemente repetitivo, estável e seguro, o bebê pode "construir" a continuidade de seu narcisismo" (Marcelli, 2007, p. 126) e sobre essa base pode dispor de sua atenção para identificar e brincar com os sinais inesperados, as surpresas e novidades provocadas pelas brincadeiras maternas.

R. Roussillon, cujos estudos a partir da clínica complexa das patologias narcísico-identitárias levaram-no a buscar nas primeiras estruturações do psiquismo a compreensão para os estados cindidos e desorganizados de muitos de seus pacientes, desenvolve uma reflexão em torno dos primeiros traumatismos e das relações entre ritmo e traumatismo. (Roussillon, 2006).

A partir de uma releitura do Projeto para uma Psicologia Científica (Freud, 895), Roussillon retoma as proposições de Freud a respeito do traumatismo e desenvolve a noção do traumatismo inaugural, o traumatismo denominado por ele de traumatismo psíquico/pré-psiquico, que paradoxalmente, se inscreve antes mesmo da constituição do psíquico e é determinante para essa própria constituição. Na verdade, tratar-se-ia do traumatismo que funda o psíquico, que se incorpora às próprias formas primeiras do psiquismo e que, por essa razão, não pode ser identificado como traumatismo, e por isso mesmo não pode ser representado.

Isso equivaleria, na construção freudiana tal como ela foi apresentada no Projeto, à primeira catástrofe que produziria a diferenciação entre os neurônios, até então todos igualmente impermeáveis, portanto, sem possibilidade de troca com o mundo externo. A primeira catástrofe, 'o traumatismo originário' atacará 
os neurônios periféricos cuja impermeabilidade será então destruída, e a partir desse ponto se iniciará a diferenciação entre dois e posteriormente três tipos de neurônios: os permeáveis (phi), os impermeáveis (psi) e os perceptíveis (ômega).

Roussillon (2006) considera que essa busca pelo 'traumatismo perdido' apresenta-se como uma exigência na clínica das perturbações graves, no registro narcísico-identitário. Torna-se quase imperativo, para o analista, o trabalho de reconstrução dos traumatismos históricos, que são desconhecidos para o paciente, mas que deixaram marcas indeléveis em sua própria constituição psíquica. Essas proposições de Roussillon inscrevem-se numa abordagem da inscrição do traumatismo, de sua complexidade tópica, pois "não há representação da ausência de representação, não há representação do trauma", o traumático sendo definido como "ausência de representação" (Roussilon, 2006, p. 227).

No entanto, o autor pensa que a ausência de traço representativo não significa a ausência de todo traço, como mostram algumas manifestações que o analista pode considerar como "representantes não psíquicos (poderíamos dizer, psíquicos/pré-psíquicos) do trauma" (Op. cit., p. 228), tais como alguns sintomas psicossomáticos ou psicóticos, alguns processos autísticos ou patologias do narcisismo. A abordagem clínica sugerida por Roussillon (2006) para esses casos é a de um trabalho de reconstrução do traumatismo perdido, tomando como ponto de partida esses traços psíquicos/prépsíquicos até chegar a uma apresentação ou encenação do traumatismo. Esses seriam os mesmos traumatismos que Winnicott considerou como não representáveis, "porque o sujeito não estava lá para representá-los" (Winnicott, 1960).

Ao abordar as relações entre o ritmo e o transicional, Roussillon (2006) discute os aspectos quantitativos e qualitativos do traumatismo, e propõe a idéia de que o trauma

...não pode ser nele mesmo nem qualitativo nem quantitativo, na medida em que é precisamente caracterizado por uma desorganização das relações da força com o sentido, da quantidade com a qualidade... e que entre os componentes 'qualitativos' do traumatismo, o problema da temporalidade aparece em primeiro plano (ROUSSILLON, 2006, p.232).

Dessa forma, afirma que na teoria não se pode separar a abordagem quantitativa da abordagem qualitativa do traumatismo, ainda que na clínica muitas 
vezes seja necessário privilegiar uma ou outra entrada, dependendo das condições particulares dos efeitos traumáticos para cada paciente.

Roussillon (2006), ainda que reconheça que ele mesmo hesita entre o tempo como categoria cronológica e o "tempo próprio" como apoio do ego infantil, sustenta por fim que os processos secundários da criança se organizam com outras formas de temporalidade, uma delas sendo justamente o ritmo.

Referindo-se ao Projeto (Freud, 1895), Roussillon aponta o fato de Freud ter, no mesmo momento, introduzido a importância de um objeto no exterior ao qual é dirigida a demanda - "a pessoa bem informada", e no interior, o sistema psi e o período, que, para ele, designa o que hoje chamamos de ritmo. Nesse ponto do texto freudiano, a criança às voltas com uma emergência de excitação deve encontrar no exterior o objeto ligado à satisfação do qual ela possui um traço interno. Precisam então coincidir, segundo a leitura de Roussillon, o ritmo interno, o traço interno e o objeto exterior, para tornar possível a satisfação em boas condições. Assim, num "bom" ritmo, num bom período, a quantidade torna-se aceitável para o sistema; em contrapartida, a disritmia constitui a quantidade como uma efração que deverá ser descarregada.

Roussillon vai relacionar essa descrição com o que, muito mais tarde, Winnicott descreverá como a experiência do objeto encontrado/criado. Quando há harmonia entre o ritmo interno, o traço interno da experiência de satisfação e a ercepção exterior, tem-se a experiência do objeto encontrado/criado, e, segundo ele, é a harmonia que caracteriza essa experiência. $\mathrm{O}$ autor propõe então que essa harmonia interna/externa dependeria do ritmo da presença/ausência do seio, porém ao utilizar aqui a noção de ritmo, amplia e modifica essa compreensão. Assim:

Mas a noção de ritmo... não indica algo mais que uma simples simultaneidade da necessidade interna e do objeto externo? Não há também, implicitamente, a idéia de uma adaptação e de uma harmonização suficiente dos ritmos interno e externo durante a própria experiência de satisfação? Em outras palavras, não é preciso uma harmonização suficiente dos diferentes ritmos - o da sucção, das pressões da mão de ambos, da continuidade/descontinuidade do fluxo de leite, da respiração, etc.- para que a satisfação ocorra verdadeiramente como algo encontrado/criado? E, mais do que isso, não deve essa experiência arquetípica colorir, de uma maneira geral, todos os cuidados maternos precoces? (ROUSSILLON, 2006, p. 236-237). (grifos do autor) 
Nessa perspectiva um bom ritmo indicaria para a criança a união simbólica harmoniosa primária, enquanto que a desarmonia, a disritmia, daria a ela a impressão de um mundo incontrolável. E essa experiência se transmite passando pelas mediações corporais, modo de concretização da relação afetiva mãe/filho, expressão dos fantasmas subjacentes. Essa compreensão relaciona-se muito diretamente ao conceito de sintonização afetiva de D. Stern (2000).

Mas quando a sintonização falha repetidamente, a experiência é a da disritmia. A criança se vê então às voltas com um mundo que se apresenta ou incontrolável, quando o objeto chega rápido demais, ou desesperador, quando o objeto tarda para além do limiar suportável para o bebê. Como essas experiências se dão no tempo da indiferenciação subjetiva primária, ainda no tempo em que si e o outro não estão distinguidos, no registro do narcisismo primário, elas deixarão, se repetidas, "um núcleo de culpabilidade primária ou de um tropismo voltado para o 'narcisismo de morte', como escreve Green (1983)" (Roussillon, 2006, p. 237). Trata-se, nesse caso, de uma forma de "traumatismo perdido", que não é reconhecido enquanto tal, porque "o sujeito atribui a si mesmo, na ilusão primária, a causa de seu mal-estar”, já que "o caráter traumático das inter-relações precoces não pode ser reconhecido como tal" (Roussillon, loc. cit.). O traumatismo seria um efeito da disritmia, do desrespeito à lei biológica, ao ritmo próprio ao sujeito.

É pela aceitação do ritmo "biológico" que nos abstraímos da quantidade e temos acesso às qualidades psíquicas. E, pergunta Roussillon, “não seria essa 'lei bio-lógica' também uma 'lei materna', uma lei do respeito do ritmo próprio que falta nas patologias narcísicas?” (Roussillon, 2006, p. 233). V. Guerra (2014) comenta sua surpresa com a referência de Roussillon a uma "lei materna", já que nossa referência habitual é à "lei paterna" como uma marca de separação necessária entre a mãe e a criança. Mas pergunta por que não pensar numa lei materna, que seria uma forma de regular, através de processos empáticos com o bebê, um aspecto básico do funcionamento do sujeito para tornar possível a vida com os outros, "uma lei materna do encontro", que seria um princípio de organização da vida afetiva do bebê como sujeito em constituição. (Guerra, 2014, p. 2). A partir dessas reflexões, podemos pensar a função de holding materno (Winnicott, 1951) como um modo privilegiado de transmissão desta "lei do encontro", entre o bebê e seu objeto primordial. 
Por outro lado, lembrando a proposição de Green (1988) segundo a qual o encontro com o objeto carrega em si a condição traumática, tal como ele o define com a noção de objeto-trauma, avançamos a idéia de que o ritmo pode ser um dos elementos de tratamento desse paradoxo, um elemento que faz a cola, a liga, compondo o registro primário que constrói uma sensação de continuidade da experiência compartilhada com o objeto, sendo, como indica Marcelli (2000/2006), o que permitirá a construção da continuidade do narcisismo. Sugerimos que a ritmicidade conjunta, que pode ser entendida como resultante de um trabalho indissociável da pulsão (sujeito) e do objeto, seria o elemento permitindo ao bebê lidar com o traumático inevitável do encontro com o outro. No melhor dos casos, e na maioria das vezes é ele que acontece, o ritmo compartilhado oferece uma vertente criativa da relação da mãe com seu bebê, que torna previsível sua presença e antecipável sua ausência. Ao contrário, se houver disritmia ao invés de "bom ritmo", estaremos no campo das falhas no trabalho psíquico de diferenciação, prévio à separação, e essas falhas farão marca nos próprios processos constitutivos do $\mathrm{Eu}$.

\section{2}

\section{A estrutura enquadrante e a função simbolizante do objeto}

Podemos considerar que há dois elementos centrais que devem se articular para favorecer os processos de simbolização primários: a qualidade da presença do objeto, e a importância do trabalho do negativo, que resultará no apagamento do objeto primário e em sua transformação em estrutura enquadrante. Se a presença do objeto é fundamental para possibilitar a representação de sua ausência, o trabalho do negativo é igualmente determinante para permitir a instauração dos limites entre interno/externo, entre sujeito e objeto. Serão as diversas manifestações do trabalho do negativo que irão permitir a ausência enquanto presença em potencial, "requisitos básicos que garantem não apenas a possibilidade de separação eu/outro, mas também a condição desejante e a vigência do pensamento" (Garcia, 2010, p. 32).

As noções de estrutura enquadrante e de função simbolizante do objeto, que foram propostas respectivamente por André Green e René Roussillon, tratam, 
cada uma a seu modo, das funções do objeto na sua relação com o sujeito, levando em conta o movimento pulsional. O que está em questão para ambos os autores são as funções do objeto que oferecem ao infante as condições para a diferenciação e a simbolização, e podemos encontrar pontos de contato entre as duas concepções.

R. Roussillon, (2010) sustenta que a teoria do sujeito e para o sujeito é também, necessariamente e simultaneamente, a teoria do objeto e de como ele permite ao sujeito se subjetivar. Anteriormente, A. Green já havia apresentado hipóteses importantes a respeito das funções do objeto como determinantes para a constituição psíquica, em interface com os movimentos pulsionais do sujeito (Green, 1988, 1993). Em sua concepção, a relação entre pulsão e objeto é complementar, "o objeto não apenas revela a pulsão, mas também é por ela construído através do investimento pulsional" (Garcia, 2010, p. 38). Segundo Garcia, a compreensão dos destinos da relação pulsão/objeto no pensamento de Green requer a consideração do trabalho do negativo, como expressão da atividade de negação que permitirá estabelecer limites que possibilitem a atividade representacional.

Partindo da posição freudiana a respeito da ação conjunta da pulsão de vida e da pulsão de morte nas suas tarefas de ligação e de desligamento, Green vai atribuir funções diferenciadas a cada uma das pulsões. Assim, a pulsão objetalizante, no campo das pulsões de vida, opera no sentido de ligar e compor unidades cada vez maiores, enquanto a função desobjetalizante atua no sentido da ruptura e do desligamento. $\mathrm{O}$ trabalho do negativo se insere no campo da função desobjetalizante, pois se apresenta sempre como uma forma de negação (Garcia, 2009). Nessa formulação, Green apresenta a função estruturante da pulsão de morte como fundamental na relação com o objeto, função que aponta "para a necessidade do trabalho do negativo na separação do objeto primário" (Garcia, 2012, p. 28).

A partir da importância central que Freud (1917) dá ao objeto em Luto e melancolia, Green aprofundou a discussão sobre as funções do objeto, articulando-as com a negatividade, idéia já presente no texto freudiano, porém não suficientemente desenvolvida, segundo ele. Assim, Green vai postular que "o objeto absolutamente necessário para a estrutura psíquica deve se apagar” (1993). 
O apagamento do objeto por meio da alucinação negativa vai permitir o surgimento de uma estrutura enquadrante. Essa noção, como também o papel ativo da alucinação negativa da mãe constituem aspectos essenciais da posição materna.

...O papel crucial atribuído ao trabalho do negativo na construção das fronteiras psíquicas atesta a importância da descontinuidade, representada pela negação, na constituição psíquica. Na argumentação greeniana, portanto, é fundamental a função realizada pelo trabalho do negativo na delimitação dos limites externo-interno o que se realiza não apenas através dos diferentes mecanismos de defesa, mas também, e principalmente pela ação do apagamento do objeto absolutamente necessário (GARCIA, 2010, p. 42).

Na perspectiva de Green, a função do objeto é intrinsecamente paradoxal, pois ao mesmo tempo que estimula, contém e limita a pulsão. O paradoxo também se apresenta quando, de um lado, está enunciada a necessidade absoluta do objeto, e de outro, a condição de seu apagamento para que se constitua o espaço psíquico do sujeito, a ser habitado por objetos substitutivos.

A noção de estrutura enquadrante encontra de modo próximo a descrição de Roussillon (2010), sobre a dupla posição do objeto em relação ao sujeito que vai permitir a simbolização. Segundo esse autor a complexa tarefa do bebê antes da constituição da linguagem verbal é a de ligar-se ao e ao mesmo tempo diferenciar-se do objeto.

Além disso, perceber a mãe é uma coisa, concebê-la como outro-sujeito que tem seu próprio desejo é uma outra (Roussillon, 2008). O bebê organiza seu estado inicial de nebulosa subjetiva (David, 1997), por meio de um trabalho de juntar, compor, integrar as experiências até poder sintetizar. A ligação interna das experiências, subjacente à capacidade de síntese, que pode ser relacionada ao processo de integração descrito por Winnicott (1960), deve ser dialetizada permanentemente com a qualidade da ligação ao objeto, dela depende. Para além do postulado de que a simbolização nasce da ausência, compreende-se atualmente que o papel do objeto em sua presença é fundamental para que o processo de simbolização possa se engajar. Segundo A. Ciccone (2007), "prévia à simbolização da ausência está a simbolização da presença", referindo-se ao processo de simbolização primária que depende dos modos de inscrição e de ligação do sujeito com seu objeto primordial. 
Roussillon (2010) propõe chamar de simbolização primária as operações que fazem passar a "matéria-prima psíquica" (Freud, 1900) - um amálgama de elementos sensoriais, perceptivos e motores, investidos de diferentes moções pulsionais e misturando o sujeito e o objeto, correspondendo ao registro da experiência sem outra transformação além da necessária para sua inscrição, os traços mnésicos - à representação de coisa, para chegar à representação de palavra, no sentido freudiano do termo. O autor ressalta a importância da ação recíproca das competências inatas do bebê e do ambiente, pois para poder acontecer, esse processo de simbolização primária passa necessariamente pelo 'outro' do bebê. Por esse motivo, faz-se necessário compreender melhor a função do objeto, não somente em relação à sua oscilação entre presença e ausência, mas também na qualidade de sua presença.

O processo de subjetivação corresponde para R. Roussillon (2008) a um trabalho em três níveis, de atribuir um signo, de encenar e de dar sentido à experiência subjetiva, de tal modo que as pulsões investindo os traços mnésicos perceptivos se transformem em representação, e possam se auto-representar de maneira reflexiva. Como propõe o autor, "a subjetivação é o resultado de uma simbolização que reflete seu próprio processo, trata-se de uma simbolização reflexiva" ( Roussillon, 2008, p.98). No entanto, essa apropriação subjetiva é dependente da resposta simbolizante do objeto, e quando ele falha em suas funções, estamos diante de uma experiência traumática precoce.

Por seu lado, A. Green (1988) afirma que as funções do objeto primário de continência, de espelho e de Eu auxiliar contribuem para a constituição de um Eu relativamente estável. Ele faz notar, porém que as falhas do objeto primário em suas funções podem acarretar graves perturbações na própria constituição do $\mathrm{Eu}$, falhas que podem se apresentar de três maneiras:

- O objeto antecipa a satisfação antes do desejo ser claro para a criança.

- A satisfação é dada sem amor, ou então é diferida para além das possibilidades de espera do bebê.

- A mãe projeta, difunde suas angústias sobre a criança.

Nessas condições, diz Green (1988), a ação específica do objeto, de boa torna-se má, com duas possíveis grandes conseqüências. Num caso quando houve um início razoável da relação que posteriormente se deteriorou, vê-se o 
surgimento no sujeito de angústias narcisistas como defesas contra as pulsões. No outro caso, muito mais grave, aparecem angústias psicóticas, testemunhando uma luta simultânea do sujeito contra as pulsões e contra o próprio objeto. Aqui, o objeto-trauma se transforma em "objeto louco", o narcisismo positivo se altera para narcisismo negativo, marcado pela pulsão de destruição, forma deletéria da pulsão de morte. Lembramos que em seu estudo sobre a angústia e o narcisismo Green (1988) propõe a hipótese de que o objeto, enquanto objeto da pulsão, é necessariamente objeto-trauma.

Numa direção próxima, Roussillon (2010) considera que a simbolização envolve um processo interno complexo, para o qual a natureza e a qualidade da ligação intra-psíquica, estreitamente dependente da relação intersubjetiva que a promove e a sustenta nos tempos iniciais da vida, são tão fundamentais quanto os aspectos puramente quantitativos. A apropriação subjetiva depende do reconhecimento por um outro sujeito, aspecto central da função simbolizante do objeto. Roussilon propõe ainda que as características da relação ao objeto tendem a se transferir para a relação do sujeito com sua própria atividade de simbolização, o que é uma consideração de enorme importância na clínica, tanto das psicopatologias graves da infância e adolescência, como também para os tratamentos dos chamados 'casos-limite', ou 'patologias narcísico-identitárias', como prefere chamar esse autor.

Há dois aspectos distintos e complementares da função simbolizante do objeto. O primeiro deles consiste na sua função de para-excitação, que reduz a quantidade de excitação para que ela não exceda as capacidades do infante, o que impediria seu trabalho de simbolização. Assim, o principal fator da excitação, que é a ausência ou separação do objeto, não deve exceder em sua duração a capacidade do sujeito de restabelecer, graças à representação, sua continuidade psíquica. O segundo aspecto refere-se ao fator qualitativo da organização triangular, como referência ao pai presente no desejo da mãe, que permite sair da especularidade pré-simbólica e anti-simbolizante. É preciso necessariamente haver a referência ao terceiro termo para que se dê a metaforização.

Mas, ressalta o autor, para além dessas condições gerais, é necessário aprofundar e afinar a compreensão das funções do objeto primordial, considerando especificamente o seu modo de presença. Entre tais funções, já 
foram descritos os aspectos de continência, (Bion), a função de espelho (Winnicott), a função reflexiva (Anzieu e Roussillon), todas elas também apontadas por Green. Porém restam questões que exigem novas teorizações.

Uma dessas questões diz respeito a como se dá a passagem da simbolização realizada pelo objeto para a simbolização operada pelo próprio sujeito. Outra questão envolve a delicada articulação entre os dois aspectos da função simbolizante do objeto: no primeiro, trata-se do objeto a simbolizar, que se oferece para ser simbolizado pelo sujeito, na sua presença/ausência; e o outro aspecto refere-se ao objeto para simbolizar, que, pelo seu próprio funcionamento mental - a revêrie, por exemplo - opera processos de simbolização que são progressivamente integrados pelo sujeito. O desafio é então poder encontrar o objeto e elaborar com ele mesmo a alteridade da qual ele é a causa. Simbolizar com o objeto essa alteridade supõe, portanto, o encontro com o outro - sujeito. (Roussillon, 2010)

Já na perspectiva de Green, para que a diferenciação eu/objeto se dê é preciso que o objeto primordial libere o sujeito de sua própria presença; trata-se da função de diferenciação da pulsão de morte, do trabalho do negativo operando de modo coerente no objeto. Ao contrário, temos o objeto que não se deixa apagar, que não se deixa esquecer. Porém, quando os processos correm bem, o objeto se deixará apagar para ser incorporado pelo sujeito, absorvido pelo psiquismo do bebê (Green, 1988), compondo a estrutura enquadrante.

...o objeto absolutamente necessário à elaboração da estrutura psíquica deve se apagar. Ele deve se fazer esquecer como constituinte da estrutura psíquica; ele existe sob a forma da ilusão de que ele não é constitutivo da estrutura psíquica, mas se coloca como diferente dela, como objeto de atração ou de repulsão (GREEN, 1988, p. 389).

O objeto, segundo Figueiredo e Cintra (2004) não é introjetado como "objeto interno", mas, tal como ocorre no luto, é introjetado como elemento estruturante do psiquismo. Assim ele deve se fazer esquecer, seja como objeto externo ou interno. Até mesmo sua posição como elemento constituinte da estrutura psíquica deve ser esquecida. Além disso, passando pela outra via da negatividade, a da excorporação, o objeto negado reaparece à distância em sua diferença, como objeto de atração ou de repulsão. 
Como estrutura enquadrante, o objeto primário é internalizado como funções, tempos e espaços psíquicos, oferecendo os limites externos e internos do aparelho, necessários às modulações afetivas e ao bom desempenho das operações cognitivas da mente (FIGUEIREDO, 2009, p. 91) (grifos do autor).

Estamos aqui no registro da 'mãe suficientemente boa', de Winnicott, aquela que não é 'toda' boa, que falha, que erra. Esse modo de estar presente da mãe, falível e imperfeito, cria condições para o duplo movimento de negação. $\mathrm{O}$ objeto materno é assim negado para dentro, sendo esquecido e convertendo-se em estrutura enquadrante, uma espécie de espaço interno que será a base para a vida desejante; e será negado para fora, deixando-se perder para reaparecer como objetos à distância a serem investidos. Esse processo se relaciona com o que Green apresenta como uma função paradoxal do objeto, que é ao mesmo tempo de despertar e de conter a pulsão, no mesmo movimento. Assim, as várias funções do objeto primordial, da estimulação, da continência, do desdobramento e multiplicação só podem ser bem exercidas se o objeto se deixar esquecer, isto é, se for alvo do trabalho do negativo e puder ser negado, nas diferentes formas que pode assumir o trabalho do negativo. Para Green (1998),

...é essencial para que se construa o Eu do bebê que lhe permita dizer sim para si mesmo, que a mãe aceite que ele lhe diga não. E não somente sob a forma 'você é má', como também eventualmente 'você não existe"'(GREEN, 1988, p. $378)$.

Contrariamente, se o objeto não se deixa esquecer, seja porque nunca foi bem encontrado, ou porque não tolera as próprias falhas, ele produz uma intrusão intolerável e não dá lugar à representação e ao pensamento, impedindo a instalação dos processos de simbolização. (Figueiredo e Cintra, 2004).

Segundo Green, a transformação do objeto materno em estrutura enquadrante só se efetua quando essa estrutura oferece a garantia da presença materna em sua ausência e pode ser posteriormente preenchida por fantasias e substituída por outros objetos. Nas palavras do autor, "a ausência é uma presença em potencial, uma condição para a possibilidade não só de objetos transicionais, mas também de objetos potenciais, necessários à formação do pensamento" (Green, 1974/1990, p.117). É importante ressaltar que os objetos potenciais são objetos de relação, que favorecerão o jogo entre os processos primários e processos secundários, jogo que, para o autor, deve ser um dos objetivos da análise. 
E como assinala C. Garcia (2009), a constituição da estrutura enquadrante a partir do objeto materno necessariamente imperfeito está estreitamente relacionada com a alternância entre presença e ausência da mãe, que terá uma importância fundamental para os processos de subjetivação da criança.

...Apesar de não ser ainda percebida como tal, é, então, a presença constante e fidedigna do objeto na realidade externa $-o$ que inclui necessariamente sua capacidade de ser falível - que possibilita sua ausência enquanto esquecimento, situação que, presidida pelo trabalho do negativo, encena magistralmente o jogo de presença-ausência que fundamenta todo o processo" (GARCIA, 2009, p. 85).

De seu lado, Roussillon, no desenvolvimento de sua argumentação sobre os processos de simbolização vai se servir do conceito de Winnicott (1968) de utilização do objeto, para, de certa forma, ampliar o seu alcance. Seria o momento em que se dá o deslizamento da preocupação materna primária para o registro da utilização do objeto, envolvendo jogos intersubjetivos simbolizantes. Trata-se, para a mãe, do modo como ela se presta ao jogo de simbolização do bebê, como ela aceita atenuar a lembrança de sua alteridade para permitir que esta seja assumida. Na descrição winnicottianna, a mãe vai precisar lidar com o ataque destrutivo de seu bebê quando ela falha, o que envolve três etapas que se sucederiam. Na primeira, ela deve sobreviver e se manter psiquicamente presente; na segunda, ela evita revidar ao ataque do bebê, e na última etapa o objeto mostrase criativo e vivo, e restabelece o contato com o sujeito saindo da sua órbita de destrutividade. Ao fazê-lo, afirma sua existência como outro-sujeito. Roussillon considera que é essa a etapa fundamental para a descoberta da exterioridade do objeto, as duas primeiras sendo pré-condições para a terceira. Assim, o trabalho de simbolização só se dá a partir desse encontro com a destrutividade, como já está indicado no texto winnicottiano - o vínculo não só sobrevive ao ataque, mas se revela no e pelo ataque, como ligação da destrutividade. E a descoberta da exterioridade do objeto abre o campo para o surgimento da ambivalência na relação entre ambos. O objeto sobrevive, é descoberto como objeto de pulsão, é amado. Mas também pode faltar, e por isso, passa a ser odiado pelo sujeito. Essa compreensão indica a importância do objeto operar tanto por seu próprio limite, como pelo limite que ele impõe à destrutividade do sujeito. 
A etapa seguinte será a da apresentação de objeto, como suplência à saída da preocupação materna primária. Trata-se dos símbolos primários, os objetos para simbolizar. Aqui, ainda como parte de sua função simbolizante, a mãe propõe objetos ao bebê, para sua simbolização, objetos apresentados e investidos por ela. Abre-se o campo do auto-erotismo, e junto com ele o campo do brincar, no uso e no jogo com os objetos oferecidos pela mãe e apropriados pelo bebê. Há aqui já em curso uma atividade de representação, que estava ausente na autosensualidade. Assim, a função simbolizante da mãe opera tanto na distância que ela instaura no seio da ilusão primaria da criação da criança, quanto na capacidade que ela lhe transmite de reduzir esta distância por uma criação simbólica. (Roussillon, 2010)

Tanto a modelização de Green como a concepção de Roussillon têm como pano de fundo a clínica dos chamados casos-limite ou patologias narcísicoidentitárias, e ambas oferecem compreensões fundamentais a respeito do enquadre analítico, no que se refere à posição e à função do analista, seja como objeto a se deixar esquecer (Green, 1988), permitindo ao sujeito utilizá-lo como estrutura enquadrante, ou como objeto a simbolizar, na concepção de Roussillon (2010). Aliás, a noção do enquadre na clínica psicanalítica remete "à constituição da função enquadrante de origem da mãe" (Delouya, 2012, p. 35). L.C. Figueiredo (2009) relaciona o objeto internalizado como estrutura enquadrante com a experiência da "confiança primordial", fundamental para o estabelecimento das relações entre o sujeito e o outro, que se reapresentam de modo central nas relações de cuidado e na clínica.

...Chamaremos de 'confiança primordial' a expectativa de encontro do objeto primário suficientemente bom. Trata-se de uma pré-concepção vazia à espera de realização (Bion)... Chamaremos de 'confiança primária' o que se constitui quando a pré-concepção se realiza e ocorre a internalização do objeto suficientemente bom sob a forma de estrutura enquadrante como condição para a função objetalizante (FIGUEIREDO, 2009, p. 91-92).

Essas compreensões sugerem que é preciso que o analista encontre um modo de estar presente na cena analítica que inclua, paradoxalmente, sua própria ausência, uma ausência em presença. Para assim deixar surgir a associatividade, o pensamento, a simbolização do analisando, tal como a mãe 'suficientemente boa', não intrusiva em sua ausência ou em seu excesso de presença, se encontra com sua criança. 


\section{Entre mãe e bebê: presença e ausência}

O estudo até aqui apresentou diferentes ângulos da relação entre os processos de subjetivação e as funções do objeto primário para compor as condições da simbolização. Depois de discutir os processos arcaicos e a simbolização primária, voltamos a um ponto central da pesquisa, que é a hipótese que relaciona a alternância ausência/presença materna, necessária para a constituição da continuidade psíquica, com a dinâmica da ambivalência materna e o surgimento da linguagem verbal.

\section{1}

\section{Os processos arcaicos e a simbolização primária}

Os aspectos mais primitivos da experiência subjetiva podem ser compreendidos à luz das formas primárias de simbolização. Trata-se de estudar o papel desempenhado pela sensorialidade e pela motricidade nos processos de simbolização, em sua interface com as experiências com o objeto primordial. Em realidade, as formas primárias de simbolização, compreendidas como parte fundamental dos processos iniciais de constituição psíquica, permanecem presentes ao longo da vida, e eventualmente revelam as falhas dessa estruturação inicial nas formas graves de psicopatologias da criança e do adulto que se apresentam na clínica.

Freud, nos tempos iniciais de construção da psicanálise, já se referia à importância de uma primeira memória arcaica de natureza essencialmente perceptiva, composta por traços perceptivos que não seriam traduzidos nem em imagens, nem em palavras. A carta a Fliess de 1896 (Freud, 1896) propõe um modelo dos diferentes traços no aparelho psíquico, e nela Freud distingue três tipos de signos: perceptivos, afetivos e conceituais, que serão depois posteriormente conceitualizados como traços mnésicos perceptivos e traços representativos, esses referidos como representação de coisa ou representação de palavra. (Brun, 2014). A noção de que a origem da vida psíquica está ligada a uma 
figuração do corporal está assim presente desde o início de suas reflexões e será retomada nos últimos escritos de Freud (1937), quando volta a indicar que as inscrições precoces têm um peso fundamental na construção da subjetividade. Essas inscrições precoces, mesmo não sendo lembradas porque não se constituíram como memória, já que se passaram num tempo antes da linguagem verbal, ou por causa dos efeitos do recalcamento, poderão vir a ser encenadas no corpo sem passar pela representação verbal.

As formas primárias de simbolização remetem a um originário compreendido como o arcaico, que designa ao mesmo tempo o início e o princípio. Trata-se, por um lado, da relação da criança com seu ambiente nos tempos iniciais, essencialmente durante seu primeiro ano de vida, e, por outro lado, do princípio entendido como a dimensão organizadora e estruturante dos processos de subjetivação para o conjunto da vida psíquica. O conceito de arcaico em psicanálise remete à construção do laço com o objeto e aos processos de diferenciação com esse objeto, mas não se pode esquecer que esse arcaico continua presente em cada um de nós todo o tempo. O arcaico recobriria os traços mnésicos perceptivos, que poderão ou não ser transformados em imagens e em palavras.

A clínica com bebês nos ensina muito sobre a articulação das sensorialidades primitivas do bebê com seus objetos. Os trabalhos de Stern, por exemplo, mostram que as primeiras sintonias e harmonizações afetivas do bebê com sua mãe o ajudam a aceder às primeiras formas de simbolização. É a partir de um compartilhar de sensações corporais, de ajustamento de gestos, de mímicas e de posturas entre a criança e seu objeto primário que se constitui o fundo sobre o qual se cria a possibilidade de uma sintonia emocional. Na clínica com bebês as sensorialidades primitivas tornam-se mensageiras, e se compõem com as respostas do objeto, no campo das interações iniciais.

Uma sensorialidade ecoada pelo ambiente cria as formas primárias de simbolização, ao contrário ela perde sua virtualidade simbolizadora. É a articulação entre a sensorialidade do bebê e a virtualidade potencial da apresentação de formas primárias de simbolização pelas respostas do ambiente que está na origem dos processos de simbolização(Brun, 2014, p. 5).

Em seus estudos sobre as formas primárias de simbolização, A. Brun (2014) destaca algumas noções propostas por teóricos que se dedicaram a tentar 
caracterizar as experiências vividas pela criança no registro do arcaico. A protorepresentação, o pictograma e o significante formal descrevem processos distintos e específicos, ainda que possam ser interligados, e contribuem para a compreensão desses mecanismos iniciais. São concepções que tratam de processos supostos na criança, pressupondo as respostas ou ações do objeto, sem, no entanto, se dedicarem ao estudo específico dos modos de funcionamento do objeto. Da mesma forma, as conceptualizações de G. Haag também tratam de processos constitutivos no bebê, e ainda que implicitamente todas elas considerem de o modo de presença ou ausência do objeto primordial, as características próprias do objeto não são abordadas por esses teóricos.

M. Pinol-Douriez (1984) nomeou como "proto-representações" as primeiras representações que aparecem no desenvolvimento psíquico da criança, e que designam no bebê o trabalho psíquico de inscrição da experiência e de "transformação por assimilação ativa das primeiras experiências sensórioafetivas" (Pinol-Douriez, 1984, p. 74). Essas proto-representações se constroem durante as primeiras experiências de interação entre o bebê e seu objeto primordial, e são constituídas de traços sensoriais, afetivos e motores, compondo um material sensorial e emocional primitivo, no qual a emoção ainda não está diferenciada da percepção sensorial. Da mesma maneira, não há ainda aqui a diferenciação sujeito-objeto. Nas palavras do autor "o bebê constrói suas protorepresentações e suas representações tanto quanto ele é construído por elas" (Op. cit., p. 184). Segundo a autora, essa noção tenta dar conta de uma continuidade entre a moção pulsional e a apreensão do objeto. Ela considera que a protorepresentação se harmoniza com a noção de pictograma em três aspectos essenciais: na atividade receptora, no empréstimo ao sensorial, e na indissociabilidade 'zona corporal-objeto'. Além disso, Pinol-Douriez ressalta a "importância do sensorial e em especial da motricidade e de sua ligação com à idéia da proto-representação" (Pinol-Douriez, 1997, p.17).

Já o pictograma concebido por P. Aulagnier (1975) se caracteriza por uma indissociabilidade entre o espaço corporal, o espaço psíquico e o espaço externo. Seu protótipo é o encontro originário seio/boca: o seio inserido na boca faz parte do corpo do bebê, sem descontinuidade corporal, e o pictograma no registro do originário encena a boca e o seio como uma entidade única. Essa experiência 
sensorial inaugural só pode assumir duas formas, a de tomar em si o que é prazeroso, ou de rejeitar fora de si o que não é. Aulagnier distinguiu assim uma forma originária de representação que pode ser aproximada dos "signos de percepção" descritos por Freud na carta a Fliess de 1896, para designar o primeiro registro das percepções que não terão jamais acesso à consciência. Aulagnier (1975) define o pictograma como "auto-engendramento, auto-apresentação, da psique para a psique" (Aulagnier, 1975, p.63). O pictograma se constitui pelo "empréstimo ao sensorial" e ofereceria "a segurança de que entre o espaço psíquico e o espaço fora da psique existe uma relação de identidade e de especularização recíproca" (Op. cit., p. 58, 59). Aulagnier considera o pictograma como

...a colocação em forma de um percepto pela qual se apresentam, no originário e para o originário, os afetos do qual ele é sucessivamente a sede, atividade inaugural da psique para a qual toda representação é sempre autoreferente e permanece para sempre indizível (AULAGNIER, 1975, p. 60).

O pictograma é então a inscrição psíquica originária prévia ao fantasma e ao enunciado; nesse sentido, ele se encontra com as proto-representações e com os conteúdos originários do inconsciente (Pedinielli, J.L., In: Houzel, D. et al., 2000). O pictograma é o modo de figuração no registro do originário, o qual co-existe, segundo Aulagnier(1975), com os outros dois modos de funcionamento psíquico, o processo primário, correspondendo à representação de coisa c e o processo secundário, definido pela representação de palavra ou pelo enunciado. A atividade psíquica passa então do originário não figurável à encenação, no registro do primário, e à atribuição de sentido no registro do secundário. $\mathrm{O}$ originário designa os primeiros registros no despertar da vida psíquica, aquém da diferenciação entre psique e soma, e entre espaço interno e espaço externo.

O significante formal, definido por D. Anzieu (1987) como uma impressão corporal que não apresenta distinção entre sujeito e espaço externo, e que é sentida pelo sujeito como exterior a ele mesmo, é uma sensação de movimento e de transformação. Os significantes formais remetem às proto-representações das configurações do corpo e dos objetos no espaço, como também de seus movimentos. A. Brun sugere que os significantes formais seriam representações de envelopes e de continentes psíquicos (Brun, 2014). Já para C. AnzieuPremmereur, o significante formal é imagem proprioceptiva, táctil, cenestésica, 
postural, o registro em memória de impressões, de sensações, de experiências precoces demais ou intensas demais para serem colocadas em palavras (AnzieuPremmereur, 2011).

A propósito dessas noções, Roussillon (2014) comenta que elas tratam dos processos muito iniciais de subjetivação, que representam as formas de transformação necessárias para viabilizar a apropriação subjetiva. Todas elas levam em conta a sensório-motricidade, apóiam-se sobre a sensorialidade e encenam movimentos, o que justifica atribuir-lhes o nome de processos. Porém, observa Roussillon, os diferentes autores descrevem esses processos intrapsíquicos reconhecendo que são dependentes das condições do ambiente, sem no entanto se deterem em analisar as características e as respostas dos objetos. Talvez porque esses conceitos desenvolvidos nas décadas de 1960 e 1970 ainda não se situavam no movimento que se acentuou nos últimos anos, da abordagem intersubjetiva. Atualmente, a ênfase no campo intersubjetivo pressupõe a condição do encontro intersubjetivo, a ação de um sujeito sobre outro sujeito, e isso desde os primórdios da existência da criança. A hipótese que Roussillon propõe enuncia-se então assim:

...os primeiros processos de transformação, portanto os processos que eu propus chamar de "simbolização primária" em 1991, devem, para serem apropriados, se apoiar ao mesmo tempo sobre a sensorialidade e serem inscritos, reconhecidos e validados na relação com um objeto significativo da primeira infância" (ROUSSILLON, 2014, p. 155, itálicos do autor).

Desse modo, os pictogramas, as proto-representações, os significantes formais e outros continentes formais devem se inscrever nas primeiras formas de trocas entre o bebê e seu ambiente, para que sejam tomados como formas da simbolização primária. Devem estar inscritos nas formas primeiras de linguagem não verbal que vai se constituindo entre o bebê e seus outros primordiais. Em outras palavras, Roussillon (2014) propõe integrar o lugar e a resposta do objeto nesses processos descritos no campo intrapsíquico.

Sua definição da simbolização primária é a de um

...processo que faz passar a "matéria prima" da experiência, o traço mnésico perceptivo que carrega a marca sensório-motora do impacto do encontro do sujeito com um objeto ainda mal diferenciado, mal identificado, que mistura a parte do sujeito e a parte do objeto, até uma encenação suscetível de se tornar linguagem, suscetível de ser narrada a um outro sujeito, de ser assim 
compartilhada e reconhecida por um outro sujeito para tornar-se integrável na subjetividade (ROUSSILLON, 2014, p. 165).

Nessa compreensão, a simbolização primária apóia-se sobre o modo de presença do objeto, com “a participação do ambiente à 'fabricação' dos significantes formais e dos pictogramas" (Roussillon, 2012a, p. 147) e sobre os elementos perceptivos que levarão à produção das primeiras formalizações perceptivas. A simbolização primária seria assim um processo operando a interface entre as memórias corporais, sensório-perceptivas, e o inconsciente, no qual o acontecimento sensorial é transformado em representação de coisa. Já a simbolização secundária irá ligar a representação de coisa à representação de palavra, e se faz necessária para processar os efeitos da ausência do objeto, ela exige o trabalho de luto pela perda do objeto.

Esse modelo se apóia sobre a diferenciação dos três tipos de experiência, descrita por Freud : o traço mnésico perceptivo, o traço inconsciente e o traço verbal pré-consciente. R. Roussillon (2014) retomará essa distinção de Freud em 1896 para postular que, se há três registros, "há necessariamente dois processos de transformação para passar de um registro para o outro, e na medida em que se trata de traços de representação, dois processos de produção desses traços, portanto de simbolização" (Op. Cit., p. 150-151). Serão a simbolização primária e a simbolização secundária.

Roussillon (2006, 2008) supõe diferentes modalidades operando na simbolização primária, que se desenrolariam em três tempos: um tempo intersubjetivo, um tempo auto-subjetivo e um tempo narcisista.

O "tempo intersubjetivo" é o tempo do cuidado e do jogo intersubjetivo. É na relação com o objeto que se passa a primeira forma de jogo necessária à sensação de si, à composição dos afetos, ao desenvolvimento das primeiras formas de simbolização. É nesse registro que podem ser situadas as noções teorizadas por diferentes autores, como a capacidade de reverie materna, o papel do espelho do rosto materno, a função de para-excitação. É importante que essas trocas se passem num clima de prazer compartilhado, sob a dominância do princípio do prazer, ainda que regulado pelo princípio de realidade que envolve, para a mãe, a referência ao terceiro. É através do jogo intersubjetivo mãe-bebê que começa a se dar a simbolização da ausência do objeto, em sua presença (Roussillon, 2008). 
O "tempo auto-subjetivo" é o tempo do jogo solitário, a criança desenvolve uma atividade auto-subjetiva, ao encontrar os "ob-jeux", "ob-jogos", objetos utilizados para o brincar e tomados como objetos de prazer. Esse tempo auto-subjetivo tem um valor auto-erótico a serviço do prazer da exploração e da descoberta. O objeto "meio maleável” é uma forma especial do 'ob-jogo', derivado do encontro com o objeto materno suficientemente adaptável e transformável para se ajustar às necessidades psíquicas do recém-nascido. Quando isso não ocorre haverá dificuldades para o processo de simbolização primária, e o esforço do sujeito para se tornar sujeito será o de tentar todos os meios para tornar maleável esse objeto materno rígido. (Roussillon, 2006).

O "tempo narcisico" é o tempo do sonho, da interiorização, da passagem da 'coisa que representa' à representação de coisa. $\mathrm{O}$ valor alucinatório da coisa representada pode ser conservado e contido no espaço psíquico interno. Os objetos utilizados para simbolizar deixam seus traços mnésicos a serviço da simbolização, a partir das representações de coisa. O sujeito vai poder se representar, no espaço do sonho, as experiências dos tempos auto-subjetivos e inter-subjetivos. O tempo do sonho se apresenta como uma forma de retomada dos dois primeiros tempos da simbolização (Roussillon, 2006).

O jogo e o sonho incitam à transferência das representações de coisa no aparelho de linguagem. Essa transferência representa a segunda modalidade do trabalho de simbolização, a simbolização secundária. Esta, ao mesmo tempo em que opera uma transformação, realiza uma retomada das modalidades precedentes. $\mathrm{O}$ aparelho de linguagem vai oferecer diferentes registros às transferências das representações de coisa. A complexidade do aparelho de linguagem permite uma recuperação dos diferentes registros da vida psíquica, como a ação, o afeto e a representação de coisa.

Esse processo de simbolização torna possível um processo de subjetivação, de integração subjetiva, pelo qual o sujeito humano se apropria de sua experiência vivida. Isso faz supor que os conteúdos psíquicos puderam tomar uma forma reflexiva, a subjetivação passando necessariamente pela reflexividade. Resumindo o pensamento do autor: "a matéria prima psíquica deve ser metabolizada e transformada por um processo de simbolização reflexiva para ser integrada na subjetividade" (Roussillon, 2012, p. 139). 
$\mathrm{Na}$ simbolização secundária, o aparecimento da linguagem e da ligação verbal que ela torna possível transforma a relação do sujeito com seus afetos, pois a ligação verbal permite conter, transformar e integrar as redes afetivas e as representações de coisas. Mesmo assim, as expressões corporais, tais como mímicas, gestos e posturas, podem acompanhar as narrativas verbais, elas dão corpo e expressividade à comunicação verbal, ajudando a transmitir o que as palavras não conseguem expressar por elas mesmas. Isso se dá também pela prosódia, que envolve a intensidade, o ritmo, o timbre da voz, etc.

A linguagem verbal é também corpo, não pode ser enunciada sem a participação da voz e do conjunto de sua expressividade, do conjunto de sua prosódia. É também ação sobre o outro... participa da maneira como os conteúdos psíquicos são transmitidos em ato, a esse outro" (ROUSSILLON, 2012, p.151).

Assim, as formas primeiras de linguagem que envolvem os afetos e a expressividade corporal, testemunhas dos primeiros tempos da vida psíquica, das primeiras tentativas de trocas e de comunicação, mantêm-se ao longo de toda a vida, mesmo quando a linguagem verbal já assumiu a dominação sobre as outras formas de expressão.

A simbolização em presença e a simbolização em ausência do objeto. B. Golse (2007) tem uma compreensão distinta e complementar à de Roussillon em relação à diferenciação entre simbolização em presença e simbolização em ausência do objeto, tomando o pensamento de Freud como referência.

Para Golse trata-se também de articular a problemática dos processos de simbolização do objeto em presença e na ausência dele, tendo como objetivo compreender o trabalho psíquico dos bebês em presença e em ausência. Segundo ele, já se disse que a psicanálise seria uma espécie de metapsicologia da ausência, enquanto que a teoria do apego seria uma teorização sobre os efeitos da presença do objeto. No entanto, os desenvolvimentos mais recentes das teorias psicanalíticas têm, ao contrário, apontado para o fato de que a ausência e a presença são no fundo indissociáveis, e que o que importa é a dialética entre esses dois termos, com toda sua complexidade e riqueza.

O ponto de partida dessa dicotomia teria sido, segundo Golse, resultante de duas indicações distintas de Freud (1915, 1925), que porém não são excludentes. Há, por um lado, sua afirmação categórica segundo a qual "o objeto nasce na ausência" (Freud, 1915), e, na direção oposta, sua observação de 1925, 
no artigo "A negativa", quando afirma que toda representação supõe que houve inicialmente o encontro com o objeto, e, em especial, com o objeto que foi fonte de satisfação. A contradição seria então no fundo só aparente, as afirmações de Freud podendo ser entendidas de modo complementar: a presença do objeto é inicialmente necessária, e sua ausência, fator para uma nova apresentação ao sujeito, uma "re-presentação" do objeto que falta. A falta do objeto só se dá porque ele foi antes encontrado, como aliás está no próprio texto freudiano, o encontro com o objeto é sempre um reencontro (Freud, 1905). Assim, não há em Freud um privilégio dado à dimensão da ausência, porém os estudos subseqüentes em psicanálise se dedicaram aos efeitos da ausência muito mais do que aos impactos da presença. Ou, dito de outro modo, a reflexão psicanalítica voltou-se mais para a simbolização do objeto ausente do que do objeto presente, a própria noção de simbolização sendo intrinsecamente ligada à ausência. Talvez tenha sido em parte a teoria do apego que provocou esse olhar para a simbolização em presença do objeto, apesar das críticas e das resistências que a teorização sobre o apego encontrou no ambiente psicanalítico.

É importante ressaltar, no entanto, que a simbolização em presença do objeto tem características próprias, diferentes daquelas da simbolização em ausência do objeto, são processos claramente distintos um do outro. O encontro inicial do bebê com o objeto materno dará lugar a uma simbolização primária dos laços de apego e de suas eventuais variações, enquanto que as ausências do objeto darão lugar a uma simbolização secundária a partir dos traços mnêmicos, o retorno do objeto permitindo então uma confrontação entre os dados advindos desses dois tipos de simbolização. (Golse, 2007)

Nessa hipótese, os processos de simbolização em presença do objeto e os processos de simbolização pelos registros da memória, em ausência do objeto, remetem a duas etapas de desenvolvimento diferentes, mas que permanecerão articuladas ao longo da vida. A presença do objeto dá lugar às primeiras figurações corporais (Haag, 1997) com valor proto-simbólico, enquanto pode-se supor que será a ausência do objeto que permitirá, por meio de mecanismos de evocação, a reativação dessas primeiras figurações corporais, e sua transformação em representação mental. (Golse, 2007). 
No entanto, essas duas vias de simbolização não são talvez tão radicalmente distintas. Assim, a evocação do objeto ausente pode se limitar à reativação das primeiras figurações, ainda não compostas como representações mentais autênticas. Mas, principalmente, as duas vias de simbolização colocam diferentemente a questão do objeto e de seu trabalho psíquico. As primeiras figurações corporais do bebê, tais como os "circuitos de retorno" (boucles de retour) e as identificações intra-corporais descritas por G. Haag (1985), as manobras de junção sobre a linha mediana do corpo, permitem uma figuração présimbólica, em identidade de percepção das vivências subjetivas ligadas à presença do outro e à ativação dos laços primitivos, enquanto que a passagem para as representações mentais do objeto ausente necessita fundamentalmente do trabalho psíquico do próprio objeto. Nessa perspectiva, podemos dizer que a simbolização em presença do objeto concerne não só uma proto-simbolização (Pinol-Douriez, 1984) das manifestações do objeto e de suas variações, mas também das vivências subjetivas que se ligam a esta presença, enquanto que a simbolização na ausência do objeto abre para a simbolização não somente do objeto, mas pressupõe o trabalho psíquico do objeto que o bebê progressivamente integra e interiorisa, para dele se servir para constituir e evocar suas próprias representações.

A simbolização primária corresponde às figurações corporais do encontro com o objeto, isto é, às proto-representações do objeto, dos laços com o objeto, e da vivência afetiva que acompanha esse encontro, enquanto que a simbolização secundária corresponde à re-evocação do objeto ausente e à passagem das figurações corporais às representações mentais, graças à interiorização psíquica pelo bebê do trabalho psíquico do objeto (Golse, 2007, p. 7).

Essa compreensão dos dois modos de simbolização aponta para a importância fundamental do objeto primordial para ajudar o bebê a passar da figuração à mentalização. Como ressalta S. Zornig (2015)

...o bebê só consegue transformar percepção em representação a partir de uma experiência de prazer compartilhado com um objeto que se deixa utilizar como espelho sem, contudo, perder sua singularidade como sujeito (ZORNIG, 2015, p. 125).

Essa afirmação implica o jogo entre presença/ausência e diferença. Zornig aponta para a importância da diferença nos processos de simbolização primários, pois não seria possível haver simbolização se não houvesse um espaço entre os dois sujeitos, promovendo uma primeira distinção entre um e outro. Porém, o objeto 
deve ser capaz de continência dos afetos brutos do bebê, para evitar a vivência do desamparo que poderia ser desencadeada pela experiência da distância e da diferença (Zornig, 2015). Como indica Roussillon (2008), a simbolização da ausência do objeto deve se iniciar ainda em sua presença, e isso se dá através do jogo intersubjetivo entre a mãe e o bebê, das brincadeiras com a presença e a ausência do objeto materno.

\section{2}

\section{A simbolização e a linguagem verbal}

A passagem da simbolização primária para a simbolização secundária representa uma mudança fundamental no desenvolvimento infantil, marcando uma inflexão determinante nos processos de subjetivação. A simbolização secundária é aquela que transforma as representações de coisa em representação de palavra, instaurando o uso da linguagem verbal como forma de comunicação do bebê e também como forma de organização do pensamento e dos afetos. O surgimento da linguagem e a ligação verbal que ela torna possível transformam a relação que o sujeito mantém com seus afetos, pois a ligação verbal permite conter e transformar as redes afetivas e as redes de representação de coisa. A linguagem verbal aparece como o processo central de integração psíquica.

Porém, no decorrer do desenvolvimento da criança na direção da integração proporcionada pela simbolização secundária, as experiências que precedem o aparecimento da linguagem verbal são, pelo menos em parte, retomadas no campo da linguagem, e se mantêm presentes no seu universo psíquico.

Isso se dá em parte pela ligação dos traços mnêmicos e das representações de coisa com as representações de palavras que se compõem posteriormente. As sensações e os afetos que acompanham a experiência subjetiva são nomeados e refletidos pela ligação secundária das formas lingüísticas. Com efeito, as expressões gestuais, posturais, de mímica, podem acompanhar as expressões verbais; elas dão corpo e expressividade à palavra, que muitas vezes sozinhas não conseguem transmitir toda a experiência vivida. Outro modo de presença dos aspectos não verbais da comunicação é pela prosódia, expressa pelo timbre, pela 
intensidade, pelo ritmo de enunciação da voz. Essa é uma questão importante para a clínica, pois sabemos que as experiências do período pré-verbal são determinantes para os modos de constituição e de sofrimento psíquico no sujeito.

O nascimento psíquico pode ser compreendido como um processo que atravessa várias etapas, desde o nascimento até a constituição do aparelho psíquico, com o surgimento da linguagem verbal, por volta dos dois anos de idade. Nos capítulos precedentes abordamos várias das características e das condições que compõem os processos de subjetivação, desde a vida intra-uterina, a organização das experiências sensório-motoras e perceptivas, a utilização do objeto, passando pela diferenciação que permite ao bebê se ver como distinto do objeto-outro, até chegar à etapa da simbolização em ausência do objeto, ausência considerada como a condição que leva ao uso da palavra.

A partir do que foi discutido até aqui respeito das condições para o nascimento psíquico envolvendo os processos de simbolização, relembramos que ele passa necessariamente pelo outro, pelo psiquismo materno, como relembramos também a noção de que a representação do objeto se constitui na ausência , ou melhor dito, no jogo complexo de alternância entre presença-ausência. Vamos buscar aqui estabelecer uma articulação entre as características do investimento materno marcado pela ambivalência e a emergência progressiva da subjetividade do bebê, que passará pelo acesso à inter-subjetividade, inter-subjetividade que condiciona e permite o reconhecimento de que si e o outro fazem dois. A intersubjetividade é também, ao mesmo tempo, condição e expressão do acesso à linguagem verbal.

Falar do nascimento psíquico de um bebê é falar do seu nascimento à vida psíquica, ou seja, de sua inscrição na corrente de vida que pré-existe à sua chegada no mundo. Uma das questões que se coloca é a de saber como o bebê passa da relação com o outro para a internalização e a construção de sua própria subjetividade.

Há três eixos de condições prévias ao desenvolvimento da vida psíquica do bebê, segundo A. Ciccone (1997):

1. que ele disponha de um equipamento somático e neuro-fisiológico suficientemente adequado; 
2. que ele se encontre em um ambiente que pensa, com um adulto que pensa no bebê, pensando em parte por ele e em parte por si mesmo. Um sujeito só pode pensar no seio de outros pensantes, apoiando-se sobre o pensamento de um outro, ou de vários outros.

3. é preciso enfim que esse ambiente invista no bebê, e lhe atribua pensamentos.

Lembramos assim, a partir do postulado de Freud (1895) sobre o desamparo original, que a subjetividade funda-se na alteridade. $\mathrm{O}$ objeto primário passa progressivamente de continente para conteúdo do pensamento, tornando-se um objeto contido graças à interiorização pela criança da capacidade de continência desse próprio objeto primordial que passa a desempenhar internamente essa função de continente. (Bion, 1979). O bebê precisa então que a mãe atribua a ele pensamentos, e interprete seus gestos, seus atos, suas mímicas, seus choros. Para S. Resnik (1994), trata-se de uma "inter-prestação", a mãe empresta um pensamento, um sentido à expressão do bebê, e o bebê reconhece a mãe como mãe, fazendo-a nascer assim para a parentalidade. Mas essa interpretação parental - inter-prestação intersubjetiva - que ao mesmo tempo funda a intersubjetividade e é testemunho de seu surgimento, repousa sobre uma ilusão, a ilusão primária necessária, chamada por Ciccone (1997) de matriz simbiótica pós-natal, que faz crer que o bebê é uma pessoa, que ele compreende o que dizemos, e que podemos compreende-lo. Essa ilusão simbiótica é paradoxal, na medida em que enuncia a separação ao mesmo tempo em que a ignora, reconhecendo-a e ignorando-a ao mesmo tempo. O nascimento psíquico da criança é entendido como diretamente relacionado ao nascimento da representação do psiquismo infantil no psiquismo parental.

Algumas das condições para o acesso à linguagem verbal aproximam-se de nossas interrogações sobre o inter-jogo continuidade/descontinuidade no vínculo mãe-bebê. Uma delas refere-se à passagem das sensações corporais às percepções e às primeiras formas de representação, passagem que resta bastante enigmática, mas que se dá necessariamente pelo laço com o outro.

A representação e a linguagem verbal se estruturam sobre dois princípios distintos, o da separação e de estar em ligação, por mais paradoxal que isso pareça ser. O ser falante é o fruto da separação do corpo materno, mas para falar "é 
preciso estar em ligação sem perigo para a integridade de um ou do outro" (Boubli, 1997, p.157) o que envolve a necessidade de estar diferenciado do outro.

Para César Botella (1997) para que a linguagem se dê, o papel decisivo é o da ausência, a do negativo entre pulsão e representação. E a primeira descontinuidade, a mais importante, é a da ausência da mãe. "A linguagem só se inicia a partir do jogo complexo de sensorialidade, de ausência, de recuperação de lutos, para que haja representação de palavra" (Botella, 1997, p.169 ). Mas, lembra Myriam Boubli, só pode haver separação se houve inicialmente uma ligação, uma fusão intensa entre a mãe e o bebê, permitindo a instalação de uma segurança de base para a criança, o que corresponde a "ter a mãe no interior de si" (Botella, 1997, p. 160).

André Green (1997), referindo-se à separação e aos seus efeitos, considera que uma tarefa do psicanalista é a de discernir quando uma separação é estruturante e quando não o é, pois o que estaria em jogo não seria a separação em si, mas a possibilidade de reencontros. Se esta possibilidade de reencontros é pensável, então a separação só pode ter bons efeitos. Para Green, o neto de Freud ao brincar com o carretel, sabia que sua mãe iria voltar, isso estava claro para ele, e por isso ele pôde criar a brincadeira onde coloca em cena a separação. Green lembra a expressão dos gregos, que dizia que o terrível seria "perder a volta". Assim, povo de navegadores e exploradores, eles podiam ir muito longe contanto que acreditassem que poderiam retornar. (Green, 1997). Como a criança que começa a andar, e assim ganha a possibilidade de afastar-se de sua mãe. É interessante ver como, ao partir caminhando, ela vira-se para trás a fim de verificar se a mãe continua ali onde ela a deixou, como para que se assegurar de que a volta e o reencontro estão garantidos, e poder assim ir mais longe.

César e Sara Botella (1997) afirmam que para que se organize a representação de objeto, entram em conta não somente a ausência real do objeto, como também a representação da ausência imaginária do próprio sujeito.

...a ligação sujeito/objeto é sustentada pela negatividade comum às representações de suas ausência; e não existem representações de objeto que não se apóiem sobre aquelas do sujeito; nenhuma representação emerge diretamente da pulsão, a ausência, o negativo formam a fundação da representação de objeto, da palavra, e da linguagem (BOTELLA, C. e S., 1997, p. 182). 
Para apoiar essa afirmação de que a representação necessita tanto da ausência imaginária do próprio sujeito como da do objeto, eles lembram que na seqüência do jogo do fort-da, depois do jogo com o carretel, o neto de Freud brinca de se fazer desaparecer e reaparecer a si mesmo diante do espelho, como se, ao se ausentar ele mesmo no espelho, ele reencontrasse imaginariamente o objeto que partiu, numa identificação si/objeto, e o retomasse a seguir na linguagem (bebê - ooo). Estão em jogo aqui várias dualidades: sujeito/objeto; aqui/não-aqui; presente/ausente. Assim, criada no lugar do ausente, a palavra "é a herdeira do que Winnicott descreveu como o bebê se olhando refletido no rosto da mãe" (Botella, C.e S., 1997, p. 189). A palavra é ao mesmo tempo separação e união, presença e ausência, alteridade e continuidade, e cada representação de palavra reflete o sujeito se refletindo no objeto ausente. Como diz ainda C. Botella, a linguagem permite que o "sujeito se interprete no objeto ausente" ( Botella, C. e S., 1997, p. 189).

"O dilema trágico da linguagem”, nas palavras de B. Golse (2005) é o de evidenciar a separação pelo fato mesmo de fazer a ligação. Só é possível, e necessário, ligar dois termos se eles estão separados. A linguagem verbal obriga à constatação da distância intersubjetiva. Enquanto se está aquém da intersubjetividade, incluído no outro e colado a ele, não é necessária a linguagem, e, mais ainda, não é possível a linguagem. A comunicação, nesse tempo, passa por outras vias, pelas vias do analógico, do pré-verbal, do corpo. São as formas de simbolização que se passam na presença do objeto, a simbolização primária em suas várias formas de expressão. Em verdade, para que os modos elaborados de simbolização, envolvidos na linguagem verbal possam acontecer é preciso que tenham se dado previamente as outras formas de linguagem, em suas várias modalidades de relação e de comunicação com o objeto. Para que se possam se inscrever nas formas de linguagem verbal as experiências precoces devem se inscrever nas formas pré ou não verbais de linguagem. A questão derivada disso é então: quais são as condições para que uma experiência precoce possa 'se tornar linguagem' no seio das relações primitivas que ligam o bebê ao seu ambiente?

R. Roussillon (2006) lembra que entre ausência e presença apresentam-se modos de relação intermediários, transicionais, nos quais a presença do outro se faz tão discreta que é possível ter-se a ilusão da ausência, como se dá na 
capacidade de estar só na presença do outro, passagem essencial no desenvolvimento da subjetividade e da simbolização. São os jogos que o autor chamou de "jogos auto-subjetivos" (Roussillon, 2006, p. 77), nos quais a criança brinca sozinha na presença do objeto.

Nas últimas décadas desenvolveram-se uma série de pesquisas sobre os chamados significantes arcaicos, como mencionamos no capítulo anterior. Todas essas pesquisas têm no fundo dois pontos comuns: de um lado elas insistem sobre a base corporal dos sistemas de simbolização precoce, e, de outra parte, elas situam a origem desses sistemas no contexto das primeiras interações. A criança só pode processar suas percepções sensitivo-sensoriais em presença de um parceiro interativo, a mãe em geral, que dá forma e sentido a essas percepções iniciais.

Trata-se aqui dos primeiros níveis de simbolização, a composição de significantes elementares cuja emergência e especificação não se refere à ausência do objeto libidinal, mas ao contrário se apóia sobre a garantia de sua presença. Esse é o tempo da presença da mãe, indispensável em sua função continente. Ainda não se trata aqui do luto do objeto primário ou do terceiro separador, de quem se sabe a importância para o surgimento das simbolizações lingüísticas.

Já na etapa das simbolizações lingüísticas assiste-se à primazia da ausência do objeto, mas vimos como na primeira etapa o objeto primário é necessário, fornecendo à criança um apoio, uma matriz para a extração das configurações significantes e para a combinação mental delas. Para o que nos interessa, no caminho da simbolização há um ponto de báscula absolutamente essencial. Antes dele são a presença e a continuidade da função materna na realidade que permitem à criança criar as primeiras estruturas significativas de seu ambiente, estruturas significantes elementares, de natureza sensorial mais do que verbal, e que poderão permitir uma evocação interna parcial do objeto. Para além desse ponto de báscula, será a ausência mesma do objeto primário que deverá ser simbolizada.

Uma ilustração desse ponto de báscula são as identificações intra-corporais descritas por G. Haag (1985), que designam a capacidade do bebê a representar em seu corpo uma ou outra função materna, principalmente as funções alimentares, em presença da mãe em períodos de pausas na interação. A meio caminho entre a presença e a ausência (mãe presente, função em suspenso) esse 
sistema corporal de representações permitiria à criança começar a integrar e a interiorizar suas inter-relações primitivas com o objeto primordial, a construir um pensar sobre o objeto, a compor seus primeiros esboços de teorias. $\mathrm{O}$ bebê cria assim as "imagens motoras", que são precursoras das representações mentais. B. Golse (2006) indica que esses movimentos significativos do bebê têm função de pensamento, em ação e em experimentação. "Pensar, agir e sentir são, no bebê, totalmente indissociáveis”. (Golse, 2006, p. 191). Por fim, é a função materna que irá inicialmente ajudar a instalação dos primeiros sistemas de simbolização, os quais funcionarão, mais tarde, como a base para a simbolização da mãe ausente.

Assistimos assim a um deslocamento que faz passar a mãe de uma primeira função de enquadre e de apoio para as simbolizações precoces a uma segunda posição de objeto a simbolizar, porém que guarda sua função matricial enquadrante primeira. A oposição continente-conteúdo não dá conta inteiramente desse deslizamento funcional porque o objeto a simbolizar (conteúdo) é ou foi ele mesmo fundador da função simbolizante (continente) (GOLSE, 1990, p. 195).

Trata-se assim para a criança de se servir da presença da mãe, em suas várias funções, para colocar em funcionamento os processos que conduzirão posteriormente à simbolização da própria ausência da mãe.

Sendo essas em linhas gerais as condições para o acesso à linguagem, vamos examinar mais de perto os mecanismos e as modalidades de construção da linguagem verbal pela criança. A cadeia falada compõem-se de um conteúdo e de um continente, o primeiro remetendo aos elementos do enunciado, o segundo às regras da enunciação, de um lado e, de outro lado, ao que se chama de música da linguagem (prosódia, timbre, tom, intensidade da voz, ritmo, silêncios). B. Golse (2005) indica que a cadeia falada compõem-se de uma parte segmentável, seu enunciado lingüístico, e de uma parte não segmentável, que é sua enunciação de tipo musical, sendo que essa última veicula provavelmente a expressão das condições afetivas de sua enunciação. $O$ bebê parece inicialmente muito mais sensível à música da linguagem e dos sons, do que à significação dos signos, que ele aprenderá a decifrar somente como o correr da aprendizagem. Assim, nas interações sonoras entre o bebê e a mãe, a voz da mãe pode ser vista como o primeiro elemento da pulsão. A. Green afirma "ser evidente que a linguagem não é primeira na comunicação, que o que é primeiro, e em estreita relação com a atividade pulsional de base, é a música.” (Green, 1997, p.162). Nessa dimensão é 
preciso levar em conta a relação entre continuidade e descontinuidade, sendo a alternância entre ambas fundamental para a constituição de uma identidade pessoal.

É preciso que o bebê se constitua uma "mãe sonora" interna, e Anne Denis (1997), evocará sucessivamente algumas das condições que ela considera necessárias para o acesso da criança à linguagem verbal:

- é preciso que o bebê experimente "a música no interior da mãe"; o comportamento musical das mães de crianças autistas aponta para a ausência dessa dimensão, quando a música está colocada no exterior, no real; no interior da mãe não há música, isto é, a pulsionalidade está barrada.

- mas não é suficiente que haja música, é preciso também que haja a pulsão de destruição para que a linguagem se instaure, com a condição de que essa pulsão de destruição seja temperada pelo Eros da mãe, para que possa haver introjeção da pulsionalidade pelo bebê. “A música representa o Eros originário absoluto a partir do qual a pulsão de destruição pode realizar sua função (separação e abstração) sem ser violência" (Denis, 1997, p. 170-172).

- a separação necessária aparece como exercício da pulsão de morte, no sentido de que esta permite existir independentemente do objeto, experimentar o prazer da separação e da individuação, construir uma linguagem articulada.

Lembramos aqui a distinção feita por Green dentro do campo da pulsão de morte. Assim, se de um lado há uma pulsão de morte cujo verdadeiro fim é a destruição mesma do sentido, que não opera no jogo ligação-desligamento, mas sim no registro do "puro desligamento" (Green, 1997, p. 239), há outra parte da pulsão de morte que, pelas interrupções que produz, cria a descontinuidade, prérequisito para o surgimento do sentido. (Green, 1997). Seria essa a parte da pulsão de morte integrável pela pulsão de vida materna, ou pelo Eros materno, como diz Anne Denis.

Qual a relação do bebê com a música dentro da mãe? Sabemos que o feto, principalmente no final da gravidez, ouve os sons no interior do corpo da mãe, sons internos e externos. Entre os sons internos, há aqueles vindos do próprio corpo materno, e que são regulares, (batimentos cardíacos, por exemplo) ou irregulares (ruídos digestivos, voz materna transmitida internamente). Já os sons externos são todos imprevisíveis, e entre os quais, de novo a voz materna, mas 
dessa vez vinda de fora. Assim, a voz materna seria ao mesmo tempo, para o feto, interna e externa, e Bernard Golse cita a hipótese de S. Maiello

...segundo a qual a imprevisibilidade da voz materna (seja o 'objeto sonoro') forneceria ao bebê uma espécie de matriz prototípica de sua dialética posterior entre presença e ausência, e que à esse título ela contribuiria para a gênese do objeto ele mesmo (GOLSE, 2005, p.18).

Mas a voz materna, como todo estímulo sensorial, precisa ser segmentada para ser percebida, e ela só pode sê-lo de duas maneiras, ou pela própria criança, pela variação de seu estado de vigilância ou de atenção, ou pela própria mãe, quando ela introduz variações na música de sua linguagem.

$\mathrm{Na}$ interface do dentro e do fora, no entre-dois do bebê e da mãe, a voz materna se coloca então como um elo central do desenvolvimento da criança e de seu acesso à linguagem verbal. ... A mãe desempenharia assim o papel de um maestro das diferentes segmentações sensoriais de seu bebê, como um maestro ajudando-o a segmentar seus diferentes fluxos sensoriais segundo ritmos compatíveis, e ao fazê-lo, atuaria como uma ajuda ao 'mantelamento' de suas sensações e ao acompanhamento de sua criança na direção de uma intersubjetividade estabilizada". (GOLSE, 2005, p. 19 )

Para que se dê a percepção da voz materna, são necessárias as condições de movimento, de presença e de ausência. O som é onda, os corpos vibram, e essa vibração se transmite para a atmosfera sob a forma de uma propagação ondulatória, que nosso ouvido é capaz de captar e o cérebro de interpretar, dandolhe figurações e sentidos. Mas para isso o som como onda sonora, precisa obedecer a uma periodicidade, uma ocorrência repetida dentro de uma certa frequiência (Wiznik, 2004), numa seqüência de impulsos e repousos. Assim, a onda sonora é composta por um sinal que se apresenta e pela ausência que pontua a apresentação do sinal. Não há som sem pausa, sem o lapso o som sequer começa. Vemos então que o som é presença e ausência, e está, mesmo que assim não pareça, permeado de silêncio.

Ao evocar essas características do som, fazemos a aproximação com o que se dá na interação mãe-bebê, nas alternâncias de presença e ausência, de falas e silêncios. Certamente não se pode isolar somente no registro da voz materna tudo o que está em questão na complexidade do jogo interativo mãe-bebê. Importa a harmonização entre o som, o gesto, a expressão do rosto materno, como também importa o ritmo, a entonação, o conjunto entrecortado pelos silêncios maternos, 
que como vimos, são essenciais para que o som seja percebido, para que a música se instaure. A descontinuidade é fundamental para marcar a presença materna para o seu bebê.

E assim, a descontinuidade surge como expressão da ação da pulsão de morte, a parte dela que, integrável pelo Eros materno, proporciona ao bebê a experiência da pausa, do intervalo, o intervalo para "pensar", no qual seu pensamento pode emergir. $\mathrm{O}$ desligamento não é mortífero quando se trata da porção de pulsão de morte agindo integrada, contida pela pulsão de vida. E o silêncio permite criar a expectativa, a antecipação que é também uma condição para a manifestação da criação do bebê, em sua interação com a mãe. $O$ comportamento antecipatório do bebê demonstra que ele empresta intenções ao adulto, que ele assim pode começar a supor um pensamento no outro, em ressonância com sua própria capacidade emergente de pensar, por si mesmo e pelo outro.

\section{Presença/ausência materna e ambivalência}

Na hipótese de Golse (2005), há uma oscilação entre momentos de recolhimento do bebê e momentos de ligação com a mãe, com o mundo. Pode-se estabelecer uma correspondência entre essa alternância no bebê com as oscilações maternas, criadoras de silêncios e intervalos, e expressão da ambivalência inevitável da mãe. A complexidade do jogo relacional aqui é extrema, pois é preciso levar em conta, do lado do bebê, seu estado variável de vigilância, isto é, sua disposição ou não para a troca e, do lado da mãe, seu estado de ligação ou de desligamento, sob os efeitos da pulsão de vida ou da pulsão de morte. Essa retirada materna dá a chance ao bebê de "fantasiar", de pensar, o que escapa ao controle materno. O corpo não escapa ao controle materno, mas o pensamento sim (Aulagnier, 1975). Pode-se fazer a relação com a descrição greeniana da estrutura enquadrante, quando o objeto se deixa apagar. "De fato, o apagamento do objeto primário e sua apropriação sob a forma de um vazio estruturante dão lugar aos objetos substitutos e à capacidade representacional." (Garcia, 2009, p. 85).

Assim, nesse processo de diferenciação entre o sujeito e o objeto, uma parte cabe ao sujeito, mas outra parte depende do objeto, que deve permitir ao 
sujeito, em sua maneira de se oferecer a ele, que ele viva alternâncias satisfatórias de aproximação e de distanciamento, de fusão, de desfusão. Essa compreensão liga-se ao conceito de M. Milner (1990) de objeto maleável, cujas características favorecem esse processo de diferenciação. O conceito de objeto maleável pode ser relacionado com as qualidades de uma mãe 'suficientemente boa', que se oferece ao bebê como separável e como maleável, a fim de ajudá-lo a estabelecer progressivamente a distância intersubjetiva fundamental para sua constituição como sujeito separado, por meio de experiências sucessivas e cuidadosas de fusão e de diferenciação.

Os afastamentos e retiradas graduais da mãe seriam consequiência da ação da pulsão de morte integrada pela pulsão de vida (Green, 1997), que faz com que ela possa introduzir desligamentos em seu laço com o filho, através de interrupções na cadeia interativa, sonora, para deixar surgir, nesse intervalo, nesse espaço sonoro vazio, o lugar do som, do apelo, ou do jogo de vocalizes do bebê. O ódio da mãe pelo bebê, que de acordo com Winnicott (1947) não só é inevitável como necessário, manifesta-se no desligamento materno e vai permitir à criança, na dinâmica ligar/desligar, passar da relação com o outro materno à internalização desse outro em si, sendo essa a condição necessária para o acesso aos processos secundários de simbolização, quando o outro pode se ausentar pois estará representado internamente. Se a criança é fonte de ódio para a mãe, pode-se pensar que é o ódio integrado, aceito, que facilitará o prazer da maternagem e protegerá tanto o bebê quanto a mãe do perigo da fusão.

$\mathrm{Na}$ verdade, a alternância presença/ausência pode ser vista como mais complexa quando considerada a dimensão da ausência dentro da presença, e a dimensão da presença dentro da ausência. Para esta última, pensamos na capacidade que o bebê adquire de guardar em si o objeto materno, já internalizado. E talvez para que isso se dê, seja preciso que a mãe possa estar ausente na presença do bebê, num processo equivalente ao que Winnicott descreve como a capacidade da criança de estar só na presença da mãe, que testemunha de seu "sentimento contínuo de existência" (Winnicott, 1969). Assim, do lado materno, a ausência, na relação, enquanto presente, sinalizaria também sua capacidade de estar só na presença do bebê, equivalente para a mãe de seu sentimento contínuo de existir. 
Mas para que essa ausência em presença seja, para o bebê, propiciadora de autonomia, é preciso que a qualidade da presença afetiva, do investimento libidinal desse bebê por essa mãe seja "suficientemente bom", parafraseando Winnicott, de modo a favorecer um inicio de interiorização desse objeto-outro, continente, do qual o bebê se apossa, dando forma e movimento em seu corpo, depois em sua fala, a essa relação dentro de si. Ao contrário, se a ausência em presença testemunhar da dificuldade da mãe de estar em relação com esse outro o bebê - nas depressões maternas, por exemplo - veremos aberto todo o leque dos diversos arranjos patológicos possíveis no bebê.

Podemos nos perguntar o que leva, ou o que permite a uma mãe "estar só na presença do bebê”, e quais aportes isso traz para a interação. Se a mãe empresta seu psiquismo ao "infans" nesse tempo inicial, ao retirar temporariamente esse empréstimo ela o provoca, o induz, a servir-se de seu próprio psiquismo incipiente. E é nesse próprio trabalho que o psiquismo do bebê, em construção, se constrói.

É possível supor que ela "se retira" da relação nos momentos em que se "desidentifica" do bebê. Ou seria nos momentos em que, sob efeito da pulsão de morte, do ódio inevitável, ela interrompe sua participação no inter-jogo, e retira-se para seu próprio santuário narcísico. Podemos assumir a hipótese de que a maneira como esse processo se dá, isto é, dependendo do que move a mãe em sua retirada, em seu desligamento, os efeitos no bebê serão propiciadores da construção de seu psiquismo e da sua linguagem. Ou, ao contrário, se impregnados pela ambivalência materna, poderão ser devastadores e impeditivos da atividade psíquica nascente do bebê. A condição fundamental é a de que, em seus movimentos de retirada, a mãe consiga manter viva no interior dela mesma a representação de sua criança.

Na compreensão de N. Jeammet (1985) a 'mãe suficientemente boa' seria aquela que, sobre a base de sua presença, ajuda o bebê a interiorizar, a integrar e a metabolizar os efeitos de suas ausências passageiras, mas também inevitáveis. Segundo ela,

...seria uma mãe que ofereceria sua própria continuidade psíquica, que ela mesma teria construído sobre uma ausência estruturante de sua própria mãe, esta lhe tendo feito experimentar, no interior de um investimento libidinal fiável e 
previsível, o valor de ligação de uma descontinuidade da presença... (JEAMMET, 1985. p. 252).

Concluindo, retomamos a proposição de C. Botella segundo a qual "a linguagem verbal se produz a partir do jogo complexo que implica a sensorialidade, a ausência do outro, a recuperação da presença, o trabalho do luto" (Botella, 1997, p. 168). São todas condições que vão envolver processos de simbolização cada vez mais complexos até a representação de palavra e o surgimento de uma verdadeira linguagem.

Assim, o jogo entre ligação/desligamento materno, relacionado com a dinâmica entre pulsões de vida e pulsões destrutivas, será um dos fatores determinantes para tornar possível a emergência do psiquismo da criança. Como afirma Green, "O sentido surge entre Eros e pulsões destrutivas, é a isso que conduz a linguagem em Freud: a luta entre as duas pulsões, de vida e de morte" (Green, 1997, p. 239). 
Considerações finais

\section{O psiquismo do bebê e os fundamentos da posição clínica}

O campo teórico e prático da psicanálise se transforma quando a investigação psicanalítica se confronta com saberes constituídos, com técnicas rigidificadas, ou quando a cultura impõe novas formas e novos limites à vida psíquica. Assim, a partir da segunda metade do século XX as questões do sujeito, da subjetividade e da subjetivação passaram a exigir novas formulações e verificações. Nesse movimento transformador, emergem os estudos sobre a intersubjetividade, que considera mesmo antes do nascimento, a criança mergulhada nos espaços intersubjetivos. Em razão do desamparo original, o bebê humano é desde sempre aberto ao outro, e a subjetivação se dá pelo encontro com o outro, a partir das experiências pulsionais. A observação e a clínica com bebês mostraram, por outro lado, que a interação é constitutiva, é por ela que se promovem as formas de subjetividade. Assim, passamos de um estudo do intrapsíquico, que caracteriza a leitura freudiana do psiquismo, para pensar a construção do sujeito a partir da relação intersubjetiva, o que se estende à situação clínica e justifica a afirmativa segundo a qual a teoria do sujeito e para um sujeito é simultaneamente a teoria do objeto e de como ele permite ao sujeito se subjetivar. Nesta mesma direção, lembra André Green, "a atenção se dirige não ao sujeito ou ao objeto e sim à relação entre eles”. (Green, 1990, p. 52)

No desenvolvimento desse trabalho, portanto, a clínica, em especial a clínica com crianças e com bebês, que é essencialmente uma clínica da relação, foi o pano de fundo constante. Mesmo não tendo sido ela tratada diretamente, sua referência central pede para ser explicitada aqui ao final do estudo. Boa parte dos conhecimentos teóricos apresentados ao longo da pesquisa se relaciona muito estreitamente com o campo da chamada "clínica dos primórdios", cujo desenvolvimento nas últimas décadas tem contribuído de modo marcante para novos enfoques e novas construções para a teoria da clínica em psicanálise. 
A clínica dos primórdios, como também a clínica da psicose e dos assim chamados estados-limite, nas quais os aspectos narcísicos e arcaicos são predominantes, tem levado a mudanças nas teorias sobre o cuidado psíquico, que passam a enfatizar os processos de continência e o campo da intersubjetividade como o lugar da análise. Por outro lado, o conhecimento do psiquismo do bebê traz uma contribuição considerável à teoria e à prática da psicanálise, permitindo construir modelos pertinentes do cuidado psíquico, que levam a definir melhor aquilo que produz efeito de cuidado na relação clínica.

De fato, o conhecimento das condições do desenvolvimento psíquico do bebê pode esclarecer o próprio processo de crescimento psíquico e relacionar-se assim diretamente ao cuidado psicanalítico. Isso é especialmente válido para os aspectos intersubjetivos do nascimento e do desenvolvimento da vida psíquica, e para as características fundamentais das posições psíquicas parentais. O desenvolvimento do bebê e da parentalidade caminham lado a lado, e se realizam nas zonas intersubjetivas do encontro, do vínculo, da experiência compartilhada. Assim, a atenção às condições de desenvolvimento do bebê revela e permite descrever as características principais das funções parentais e essas características podem ser utilizadas para se pensar na posição do clínico em seu lugar de escuta e acolhimento das várias formas de sofrimento psíquico. Para vários autores, como Ciccone (2011), Golse (2010), Anzieu-Premereur (2011), Konicheckis (2008), a atenção ao bebê assim como a prática do cuidado e da clínica engajam a parentalidade interna, compreendida em seus aspectos de continência, atenção, transformação e suporte.

Essas contribuições fazem refletir sobre os fundamentos da posição clínica, já que o cuidado em última instância exige entrar em contato com os aspectos infantis e arcaicos do sofrimento psíquico, aqueles que provocam as experiências mais perturbadoras e mais desestabilizadoras. Trata-se então de caminhar para além, ou para aquém, do infantil edipiano, para trilhar a pista das experiências primitivas, do período não verbal do desenvolvimento infantil, situado essencialmente nos dois primeiros anos de vida. Na verdade, essa não é propriamente uma novidade. Melanie Klein dedicou-se à clínica dos primeiros anos, construindo hipóteses desafiadoras sobre o psiquismo da criança pequena, e, depois dela muitos outros psicanalistas se dedicaram a esse campo. No entanto, 
tais saberes se constituíram de modo mais sustentado e coerente desde as últimas décadas do século XX até nosso momento quando constatamos que muitas das formas de sofrimento psíquico na atualidade, caracterizadas pela fragilidade na permanência e sustentação dos laços afetivos, estão relacionadas com falhas nos processos primários de representação e simbolização, e apontam para o interesse em aprofundar o conhecimento a respeito da instauração das primeiras relações que ficarão para sempre marcadas no psiquismo, e terão papel determinante no desenvolvimento ulterior. Essas novas compreensões repercutem sobre a concepção atual da função intersubjetiva dos objetos edípicos e sua função simbolizante para o sujeito, o que influencia a clínica e sua teoria.

Nesta direção, a discussão intensa nas últimas décadas sobre os limites do campo próprio da psicanálise, que se aventurou cada vez mais nas clínicas não neuróticas - psicoses, estados-limite, e patologias da primeira infância - trouxe à tona a interrogação sobre uma mudança nos enquadres clássicos. Esse debate tem produzido reflexões sobre ajustamentos teóricos e metapsicológicos advindos da exploração clínica dessas situações extremas da subjetividade, nas quais está em jogo o próprio processo de apropriação subjetiva. Desenvolvem-se assim um conjunto de noções relacionadas à subjetivação. Trata-se de compreender melhor os processos iniciais de constituição subjetiva, e as condições que os favorecem, ou, ao contrário, os perturbam ou os impedem.

A psicanálise se amplia e se diversifica em sua clínica, o que por sua vez faz desenvolver a teoria psicanalítica. Importa pensar agora em trabalho psicanalítico para abrir possibilidades de determinar qual tipo de dispositivo clínico é indicado para acolher um determinado sujeito em sua singularidade, atendendo às suas necessidades. Há uma inversão positiva nessa abordagem, pois deixa de ser o paciente que se adapta, ou não, ao enquadre do analista. É possível pensar, ao contrário, que se trata de encontrar aquele clínico ou aquele enquadre que poderá melhor receber a demanda específica de um determinado sujeito. Mas isso exige uma redefinição da psicanálise, para além do seu enquadre. Para além do cenário da sessão, o que importa é como se coloca internamente o analista, numa posição de escuta e de trabalho, de modo a favorecer o desenvolvimento de uma transferência que poderá ser acolhida e desenvolvida. Assim, a intervenção do analista, em qualquer situação, visa a favorecer o processo de simbolização do 
sujeito e a apropriação subjetiva pelo paciente de partes de sua vida psíquica. É essa, portanto, em última análise, a disposição interna do analista que caracteriza o trabalho psicanalítico, concordando com as compreensões de Green sobre o que ele denomina pensamento clínico.

Green (2012) em entrevista a Fernando Urribarri, afirma que em psicanálise existe não só uma teoria da clínica (uma 'técnica'), mas também um pensamento clínico, um modo original e específico de racionalidade que emerge da experiência clínica ao mesmo tempo em que a funda. O pensamento clínico, segundo Green, aponta para a especificidade irredutível da clínica psicanalítica, é o que define a unidade do campo psicanalítico, que está situado no próprio analista. "O pensamento clínico é definido como o modo original e específico de racionalidade surgido da experiência prática" (Green, 2002/2007, p. 12).

É necessário, então, refletir sobre a relação do pensamento clínico com o enquadre interno do analista, tendo como pano de fundo as grandes variações do enquadre externo atualmente. Neste sentido, são preciosas as observações de Green (2002), que considera que em meio a tantas mudanças na função do analista, resta como essencial sua função de mostrar ao paciente o que ele está (se) fazendo, como uma forma de expressar o que lhe foi feito. Ao conservar sua função interpretante e apoiado sobre a reflexividade, o analista tenta tornar acessível ao paciente a representação da destrutividade que ele carrega contra si mesmo, destrutividade que está relacionada com o ódio de si mesmo decorrente da indiferença e do ódio recebido do objeto primário.

Neste contexto, a interpretação torna-se mais um processo dialógico que um ato unilateral. Mais que encontrar a interpretação justa, trata-se de sustentar a relação mantendo viva para nós mesmos nossa função interpretante. Para Green, o enquadre interno resultaria da interação de dois fatores: da análise pessoal do analista e do acúmulo de experiências com os seus pacientes. F. Urribari (2010) sugere que o modelo teórico implícito da escuta e do enquadre interno do analista é a estrutura enquadrante. Assim, nas palavras de Green:

$\mathrm{Na}$ idéia do enquadre interno, há alguma coisa da ordem do intrapsíquico e alguma coisa que permite a integração do intersubjetivo. Retomando o que assinalamos a respeito da estrutura enquadrante, poderíamos pensar que o enquadre interno é uma interface interno-externo...O fundamento desse enquadre não é talvez outro além da estrutura enquadrante do próprio analista, que pela via de sua análise pessoal torna-se fonte de uma nova reflexividade, suporte do 
enquadre interno. Se definimos a estrutura enquadrante como o que permite constituir a singularidade,... podemos pensar que o enquadre interno constitui... uma matriz aberta à singularidade do outro, à sua alteridade radical (Green, 2001, apud Urribari, 2010, p. 263).

Esta definição do enquadre interno de Green se torna ainda mais relevante no contexto da clínica atual diversificada, onde uma grande atenção é dada aos aspectos não verbais da comunicação, aos gestos, às entonações, aos ritmos. $\mathrm{O}$ trabalho em face a face, além do suporte do olhar/espelho do analista, permite também a expressão e o reconhecimento de um conteúdo psíquico mostrado mais do que dito, e que pode adquirir o estatuto de uma mensagem transferencial. $\mathrm{O}$ diálogo passa-se em dois níveis: o verbal e o gestual/mímico/motor. A cena analítica face a face parece favorecer a reintrodução na análise dos registros das experiências arcaicas, antes da organização da linguagem verbal. Assim, a indicação desse modo de trabalho, para além de 'proteger' o sujeito frágil de uma regressão perigosa, pode ser segundo R. Roussillon (2008) uma maneira de abordar e acolher os sofrimentos e as experiências arcaicas não integradas na linguagem verbal, que pesam sobre a subjetivação incompleta.

Em conferência na Sociedade Brasileira de Psicanálise do Rio de Janeiro (2012b) Roussillon referiu-se a experiências traumáticas primárias, não necessariamente intensas ou espetaculares, que podem se passar de modo sutil e imperceptível, mas que têm como característica o fato de serem experiências precoces não integradas e não integráveis em linguagem. Nessa perspectiva, o que não é integrado vem ameaçar o que é integrado, e ficaria enquistado no psiquismo como uma parte traumática por não ser simbolizável e, portanto, não estar ligada por meio dos processos secundários de representação. Dessa afirmação decorre outra questão: quais as condições para que essas experiências precoces possam vir a ser integradas? Para Roussillon, apoiado nos últimos escritos de Freud (1937/1940) a compulsão à repetição seria uma tentativa de ligar, de integrar, essas experiências não integradas durante os primeiros anos da infância.

Segundo a proposição de A. Konicheckis, (2008) núcleos traumáticos primários se criariam por um excesso de excitação ao qual o psiquismo do bebê não pode responder adequadamente. As intrusões do adulto comportam exigências quantitativas intensas que ultrapassam as capacidades de elaboração e de qualificação da criança. Esses núcleos seriam caracterizados pela dominância de 
processos psíquicos desprovidos de representação, que, diferentemente dos traumatismos mais tardios, tornam improváveis os recursos aos cenários fantasmáticos. Trata-se de experiências traumáticas precoces, de natureza mais quantitativa do que qualitativa, sem rosto e sem representação, mas com sensações e percepções. As invasões que criam esses núcleos traumáticos correspondem a falhas no sistema de para-excitação mãe/bebê. Os bebês dispõem de meios limitadíssimos de representação para qualificar as excitações e as fantasias, ainda que eventualmente uma observação fỉna permita distinguir movimentos corporais como modos de pré-simbolização, como tentativas de proto-representação das excitações. Ao nomearmos dessa forma o sistema de para-excitação no início da vida, significamos que em razão dos meios limitados do bebê, ele depende das capacidades maternas de filtragem e de estabilização das excitações, tanto as de origem pulsional como as advindas do meio externo. Sem o auxílio delas, algo ocorre cedo demais em relação às capacidades do aparelho psíquico em vias de constituição. A função de para-excitação do objeto é a de evitar que a excitação exceda as capacidades do bebê, permitindo-lhe apropriar-se dela em pequenas quantidades, o que permite e ao mesmo tempo equivale aos processos de simbolização.

A consideração desses conhecimentos a respeito dos primeiros traumatismos e da falhas nas funções dos objetos primordiais tem repercussões sobre a maneira como o psicanalista se situa em sua escuta e em seu trabalho analítico, e podemos avançar que essa repercussões não se restringem às situações analíticas desafiadoras, como os tratamentos das psicoses, das patologias narcísico-identitárias ou das distúrbios arcaicos que atingem as crianças em seus processos de subjetivação. Pensamos que esses conhecimentos sobre os traumatismos precoces, como outros saberes derivados dos estudos do psiquismo inicial, podem ser transpostos e utilizados para as situações clínicas gerais, inclusive as que envolvem os pacientes no registro dos conflitos pós-edípicos ou neuróticos, considerando que se trata para qualquer sujeito de lidar com as experiências precoces de sua história afetiva, com maior ou menor impacto sobre sua organização psíquica. Em toda análise, há momentos ou situações em que o registro arcaico se apresenta na cena transferencial, exigindo do clínico a mobilização mais intensa de sua função continente. 
Roussillon (2010) ressalta que o reconhecimento de que as experiências precoces não podem ser compreendidas sem a referência às respostas e reações dos objetos primários, amplia a perspectiva de compreensão do clínico para as manifestações transferenciais de seu paciente. Assim, segundo ele, os conhecimentos derivados da clínica do bebê têm efeitos sobre a prática, pois novas concepções dos desafios da configuração transferencial são compostas a partir do trabalho clínico sobre a vida psíquica dos bebês. Todos os analisandos tiveram sua vida psíquica marcada pelas experiências precoces, que deixaram traços em seu funcionamento psíquico atual, e isso qualquer que seja a organização geral de seu funcionamento psíquico. A linguagem verbal, em sua função integradora e simbolizadora, nem sempre abarca toda a gama da experiência subjetiva, e é por isso necessário considerar todas as formas de linguagem e de expressão, as linguagem do corpo em suas expressões somáticas, motoras, e vocais.

Dentro dessa perspectiva da clínica psicanalítica influenciada pelo conhecimento do psiquismo do bebê, Ciccone (2011) sugere que o clínico pode usar desse conhecimento para compreender e cuidar do bebê no interior de seus pacientes, que esperam encontrar um lugar de acolhimento para suas partes infantis. $\mathrm{O}$ autor propõe alguns modelos de cuidado psíquico, relacionando-os com os cuidados parentais e destacando alguns aspectos desses últimos. São eles o modelo do encontro, da integração pulsional, da reanimação psíquica e da consolação.

O modelo do encontro baseia-se na experiência que faz o bebê de seu encontro com o mundo, e principalmente com seu 'outro', com o objeto primário. Não é possível pensar o cuidado psíquico sem o encontro, consigo mesmo, e com um outro, essa é a base inicial do cuidado. Os trabalhos que descrevem a forma com a qual o bebê descobre e encontra o outro exploram a dimensão intersubjetiva da experiência, considerando a intersubjetividade como o lugar de emergência da subjetividade própria do bebê. Para Ciccone (2007) a questão do compartilhar afetivo na intersubjetividade é um dos paradigmas do cuidado. Ele toma como exemplo a noção de D. Stern (2003) do "momento presente", que se passa na paisagem intersubjetiva de uma relação mãe-bebê, ou terapeuta-paciente. O momento de encontro produzirá um novo estado intersubjetivo, um novo 
conhecimento implícito compartilhado, um novo modo de estar juntos. Cada um dos parceiros sabe alguma coisa desta relação, mas também cada um sabe que o outro sabe, e que o outro sabe que cada um dos dois sabe. Essa experiência vai definir, a cada vez que acontece, a passagem para um novo estado da intersubjetividade entre os dois parceiros dessa troca. É possível analisar da mesma maneira o que uma interpretação pode provocar e produzir no caminho intersubjetivo entre um analista e seu paciente. Em suma, as experiências de encontro intersubjetivo estão no centro dos movimentos de transformação próprios do cuidado psíquico.

O modelo da integração pulsional refere-se à disposição e à capacidade da mãe para receber os movimentos pulsionais do bebê ajudando-o a integrar sua pulsionalidade, violenta, transbordante, confusa. Essa integração pulsional pode se dar por meio de uma comunicação lúdica, que transforma a violência interna do bebê, sem se deixar destruir pelo seu ataque. Ciccone (2011) sugere que esse modelo pode ser usado como uma das abordagens para o tratamento da violência e da agressividade.

O modelo da reanimação psíquica é o que acontece, por exemplo, na relação de uma mãe com seu bebê após acontecimentos traumáticos, como uma hospitalização. No cuidado psíquico com o paciente deprimido, por exemplo, o clínico também faz uso de uma forma de reanimação psíquica, partindo dos únicos investimentos ainda existentes e buscando alargar pouco a pouco o universo dos objetos investidos pelo paciente.

O modelo da consolação remete às condutas de consolação presentes na relação parental com um bebê, parte importante do cuidado. Na situação clínica, trata-se de encontrar os meios que possam consolar o paciente de suas feridas, de seus desesperos. Uma dessas formas foi sugerida por Stern (1997), que descreve as "harmonizações falhadas propositalmente". No caso da relação de cuidado parental, o adulto reflete a expressão do bebê relativa a uma experiência vivida, diminuindo-a ou aumentando-a voluntariamente. É como se a mãe escorregasse para dentro do estado emocional da criança, podendo assim captá-lo e em seguida traduzi-lo deformado para modificar a experiência do bebê, sem quebrar o sentido da sintonização que está acontecendo. Trata-se aqui também da introdução do lúdico, do faz-de-conta, transicionalizando a experiência. É o uso paradoxal da 
sintonização, a mãe mostra ao bebê que ao mesmo tempo ela acredita, mas também não acredita, introduzindo o jogo, o lúdico, e, portanto o simbólico. Do mesmo modo quando um paciente relata uma experiência traumática, trata-se de ajudá-lo a ultrapassar a realidade bruta para fazer dela um símbolo.

Didier Houzel (apud Ciccone, 2011, comunicação pessoal) aponta três grandes modelos do tratamento psicanalítico na história da psicanálise que nos parecem esclarecedores para acompanhar as transformações ocorridas na clínica psicanalítica ao longo do tempo.

O primeiro modelo é o da descarga, que se baseia na crença no valor catártico da palavra, que esteve na origem da psicanálise.

O segundo modelo é o da revelação: o psicanalista é o especialista que vai revelar a fantasia, o conflito inconsciente, revelação que poderá libertar o paciente do peso de sua fantasmática inconsciente. Esse é um modelo ainda atual.

O terceiro modelo é o da continência. O que trata na clínica é a experiência de encontrar um espaço de recepção e de continência para a vida emocional perturbada, dolorosa. No que se refere ao analista, está em jogo sua capacidade para conter as emoções, os pensamentos, que o Eu fragilizado do paciente não consegue tolerar nem pensar.

O pressuposto de que o tratamento psíquico se dá por meio da exploração dos processos intersubjetivos não é novo em si, mas tem ocupado um lugar cada vez mais central nas teorias sobre os cuidados. Para isso contribuíram os estudos sobre o bebê, sendo a intersubjetividade uma noção central em muitos estudos sobre a primeira infância. Entre os analistas, foi Bion quem mais fortemente influenciou a importância dada a essa noção, e sua função alpha se insere num modelo profundamente intersubjetivo, de compartilhamento de experiências emocionais e afetivas. A atenção é para aquilo que se passa entre o analista e o paciente, e o trabalho analítico é visto como uma co-construção, um co-trabalho.

A partir dessa evolução do cuidado psíquico, que privilegia as funções de continência e de transformação, e que enfatiza os processos intersubjetivos, alguns princípios podem ser apontados como compondo os fundamentos da posição clínica (Green, 2012; Ciccone, 2011; Roussillon, 2008).

- A posição clínica subjetiva se apóia sobre um enquadre interno e não externo. É a posição subjetiva interna que vai permitir a escuta, o encontro 
terapêutico, e essa condição fica muito evidenciada nas práticas clínicas ampliadas, que se dão fora dos settings analíticos convencionais. $\mathrm{O}$ trabalho nas situações-limite obriga a pensar e a definir com mais clareza as características desse enquadre interno do analista.

- A posição clínica apóia-se sobre um trabalho de pensamento, relacionado com a possibilidade de simbolização. A atividade de cuidado psíquico supõe a sustentação de uma atividade de pensamento qualquer que seja a modalidade da prática. Nesse sentido, é importante ressaltar o risco da supervalorização da palavra, contraposta ao ato. A palavra, tanto quanto o ato, pode evitar a simbolização, pois ela pode ser usada defensivamente como um ato para esvaziar e evitar o processo de simbolização.

- Por outro lado, a atividade de pensar apóia-se essencialmente sobre um enquadre interno, ainda que o enquadre externo possa favorecê-la também. A experiência com bebês, com e apesar do engajamento corporal que ela supõe, ajuda a construir esse enquadre interno e a alimentar a atividade do pensamento, sobretudo quando não há elementos verbais para promovê-la, e ela precisa então se apoiar sobre elementos não verbais (Ciccone, 2011).

- A posição clínica é de dúvida e humildade. A experiência com bebês leva a adotar uma posição de humildade e de dúvida, na medida em que o desenvolvimento é muito rápido e intenso nesse período da vida, e sempre difícil de prever, e as competências do bebê são sempre surpreendentes, se sabemos observá-las (Ciccone, 2011).

A problemática essencial das terapias pais-bebê é aquela de uma falha no estabelecimento da função continente parental, que se manifesta pela descontinuidade da atenção e das referências, traduzindo-se pelos sinais de precariedade, fragilidade ou descontinuidade em seus vários aspectos de manter um fio, oferecer um suporte e criar um envelope, três aspectos da função continente, segundo R. Prat (2008). Nessa perspectiva, um aspecto muito importante da organização do tratamento reside "na instalação de um enquadre continente, no qual a atenção contínua do analista tem um papel terapêutico na reconstrução de um envelope que foi falho nas primeiras relações mãe-criança" (Aragão, 2010). É preciso que o terapeuta possa se colocar como um objeto de suporte que permita desenvolver e sustentar o sentimento de continuidade. 
O analista está colocado no lugar de acompanhante atento das idas e vindas da vida psíquica de seus pacientes, num movimento incessantemente dinâmico e em mudança. Em nossos trabalhos clínicos é bem isso que buscamos: ajudar os movimentos de vida a retomarem, englobando e eventualmente integrando os movimentos necessários de corte, impostos pelas descontinuidades internas e externas, inevitáveis. O sentimento de existir psiquicamente de maneira continua apóia-se sobre essas mesmas descontinuidades, com a condição que se mantenha a permanência interna do objeto primordial. Nesse sentido, reencontramos na posição clínica o mesmo traço central da posição do objeto primário com o sujeito, apoiando a capacidade de simbolização do paciente, a partir de uma escuta e de uma presença clínica que envolva, ao mesmo tempo, uma ausência não destrutiva, uma ausência em presença.

À guisa de conclusão, a experiência com bebês, como outras experiências clínicas, com pacientes graves, em situações extremas, em contextos não tradicionais, permite determinar melhor as características que compõem a posição clínica, que envolvem a sustentação de um enquadre interno permitindo a elaboração das condições para o trabalho do pensamento, a atenção voltada para todos os tipos de material, verbais ou não, e o enquadre oferecido como lugar de projeção da realidade psíquica.

E, por fim, o trabalho clínico mobiliza uma parentalidade interna que permite o contato com os aspectos infantis em si e no outro, e cuida deles, uma "parentalidade cuidadora" que se relaciona com o que Ciccone (2011) chama de "preocupação cuidadora primária", a partir do modelo da preocupação materna primária (Winnicott, 1956). “Essa preocupação cuidadora primária apóia-se sobre uma sensibilidade e uma atenção ao outro, à sua vida emocional, aos seus sofrimentos infantis, bebês, arcaicos" (Ciccone, 2011, p. 71).

Sustentado sobre sua base materna interna, o analista contém, sonha, pensa, funções que o ajudam a lidar com os difíceis desafios dos sofrimentos do narcisismo ferido. Ele se beneficia do conhecimento desses fundamentos arcaicos do psiquismo para o desempenho de seu papel com os pacientes visando favorecer uma mobilidade psíquica, sem atuar como a mãe reparadora onipotente, mas se servindo de suas capacidades tanto maternais como paternais. E é também no 
prazer de brincar, graças ao laço conservado com a infância, que o analista, como o artista, encontra a fonte de sua criatividade. (Anzieu-Premmereur, 2011).

O que ainda permanece como fundamental na prática clínica é a qualidade do encontro com o analista. Este encontro promove costuras de partes dispersas, as imagens e as palavras tomam corpo e retornam em novas palavras. Neste encontro, aquilo que se reconhece e se percebe através dos sentidos está em primeiro plano porque é no domínio do sensível que se constrói a existência. Isto, como psicanalistas, às vezes esquecemos, porque também somos banhados pela dispersão social e pelo imediatismo de respostas.

Esses breves apontamentos finais sobre os fundamentos da posição clínica tais como podem ser repensados a partir dos conhecimentos do psiquismo do bebê, enfatizando as relações recíprocas entre os dois campos de nossa implicação enquanto clínicos e pesquisadores, deixam em aberto várias interrogações, indicando a perspectiva de um prosseguimento no estudo dessas interfaces situadas entre a clínica dos primórdios, a clínica das patologias graves da infância, e a clínica atual de adultos. 


\section{Referências bibliográficas}

ABRAM, J. Le langage de Winnicott. Dictionnaire Explicatif des Termes Winnicottiens. Paris: Édition Popesco, 2001.

ANZIEU, D. Le moi-peau. Nouvelle Revue de Psychanalyse, Paris, n. 9, p. 195203, 1974.

. Le Moi-Peau. Paris: Dunod, 1985.

- Les signifiants formels et le Moi-peau. In: ANZIEU, D. (org.) Les enveloppes psychiques. Paris : Dunod, 1987, p. 1-22.

. Du moi-peau au moi-pensant. Paris: Dunod, 1996.

ANZIEU-PREMMEREUR, C. Fondements maternels de la vie psychique. Revue Française de Psychanalyse, 2011/5. Vol. 75, p. 1449-1488. Paris, 2011

ARAGÃO, R.O. A construção do espaço psíquico materno e seus efeitos sobre o psiquismo nascente do bebê. 120 p. Dissertação (Mestrado em Psicologia Clínica). Pontifícia Universidade Católica de São Paulo.

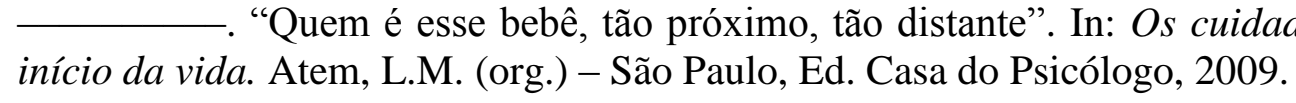

- "Où est maman? - Qui suis-je ?». In : Continuité des soins, continuité psychique. Denis, P. (org.), Toulouse, Ed. Érès, 2010.

Editora, 2011.

Tornar-se mãe de seu próprio filho, Curitiba, Honoris Causa

AUBERT-GODARD, A. Entre adulte et bébé, l'étrange désordre de la naissance. In: MELLIER, Denis (org.). Le bébé, l'intime et l'étrange. Ramonville SaintAgne: Érès, 1998.

AULAGNIER, P. La violence de l'interpretation. Paris: PUF, 1975.

Nascimento de um corpo, origem de uma história. Revista Latinoamericana de Psicopatologia Fundamental, São Paulo, v. II, n. 3, p. 945, set./1999.

BALESTRIÈRE, L. Entre mère et fille: hystérie ou mélancolie?. In: André, Jacques (dir.). Mères et filles - La menace de l'identique. Paris: PUF, 2003.

BERGERET, J. La violence fondamentale - Paris, Dunod, 1984 
BERGERET, J.; HOUSER, M. Le foetus dans notre inconscient. Paris, Dunod, 2004.

BICK, E. The experience of the skin in early object-relations. International Journal of Psychoanalysis, Londres, v. 49, p. 484-486, 1968.

BION, W.R. (1962). Aux sources de l'expérience. Paris: PUF, 1979.

BOIGE, N. Le pediatre et la grossesse. La grossesse, l'enfant virtuel et la parentalité, Paris, PUF., 2004, p. 255-272.

BOTELLA, C. et S. Pulsions, représentations, langage et travail du negative. In: Pulsions, Représentations, Langage, Org. Piñol-Douriex, Monique, Lausanne, Delachaux et Niestlé, 1997.

BOUBLI, M. Emergence du langage au cours d'um psychothérapie d'enfant. In: Pulsions, Représentations, Langage, org. Piñol-Douriez, Monique, Lausanne, Delachaux et Niestlé, 1997.

\section{. Clinique psychanalytique de la sensorialité, Paris: Dunod, 2002}

BRETHERTON, I. Communication patterns. Internal working models and the intergenerational transmission of attachment relationships. Infant Mental Health Journal, 1990, 11, 3, 237-252.

BRUN, A. \& ROUSSILLON, R. Formes primaires de symbolisation. Paris, Dunod, 2014.

BUSNEL, M.C. \& HERBINET, E. (orgs.). L'aube des sens. Paris: Stock, 1982

BYDLOWSKI, M. Les infertiles. Les méres. Nouvelle Revue de Psychanalyse, Paris, Gallimard, n. 45, p. 143-160, primavera/1992.

La transparence psychique de la femme enceinte. Alliances autour du bébé, Paris: PUF, 1998. p. 101-109.

O olhar interior da mulher grávida: transparência psíquica e representação do objeto interno. In: CORREA, Laurista (org.). Novos olhares sobre a gestação e a criança até os 3 anos. Brasília: L.G.E Editora, 2002. p. 205214.

CICCONE, A. L'éclosion de la vie psychique. Naissance et développement de la vie psychique, Ramonville Saint-Agne, Érès, 1997, p.12-37

L'experience du rythme chez le bébé et dans le soin psychique. Neuropsychiatrie de l'enfant et de l'adolescence, vol. 33, $\mathrm{n}^{\mathrm{o}} 1-2$, p. 24-35. Paris, 2005.

. Naissance à la pensée et partage d'affects. Conferência no Colóquio «Vínculos tempranos, clínica y desarrollo infantil », Montevidéo, 31 août 2007. 
La rythmicité dans les expériences du bébé, sa sécurité interne et son ouverture au monde. Conferencia. III Encontro Internacional e X Encontro Nacional sobre o Bebê, PUC Rio, 31 de outubro de 2015. Rio de Janeiro, 2015.

CRAMER, B. Que deviendront nos bébés?. Paris: Odile Jacob, 1999.

CYRULNIK, B. Éthologie des interactions precoces. Au début de la vie psychique, Paris: Odile Jacob, 1999. p. 238-256.

DAVID, M. Activité spontanée et fonctionnement mental pré-verbal du nourrisson. In: Que sont les bébés devenus ?. Cahors, Érès, 1997.

Soins maternels, soins professionnels. In: Prendre soin d'un jeune enfant, Appell, G. e Tardos, A., org. Ramonville Saint-Agne, Ed. Érès, 1998.

. Séparation précoce: traumatisme de la première enfance?. Dialogue, 2005, $\mathrm{n}^{\circ}$ 168, pp. 97-105.

Prendre soin de l'enfance. Toulouse: Érès, 2014.

DENIS, A. Discussion de l'exposé de M. Boubli. In: Pulsions, Représentation, Langage, org. Piñol-Douriez, M., Lausanne, Delachaux et Niestlé, 1997.

FIGUEIREDO, L.C.; CINTRA, E.M. "Lendo André Green: o trabalho do negativo e o paciente-limite". In: Limites. CARDOZO, M.R. (org.), São Paulo, Escuta, 2004.

FIGUEIREDO, L.C. As diversas faces do cuidar. São Paulo: Editora Escuta, 2009.

FREUD, S. Edição Standard Brasileira das Obras Psicológicas completas de Sigmund Freud. Rio de Janeiro: Imago, 1976.

(1895). Projeto para uma psicologia científica. In: Edição Standard Brasileira das Obras Psicológicas completas de Sigmund Freud. Rio de Janeiro: Imago, 1976. v. I, p. 395-517.

. (1900). A interpretação dos sonhos. In: Edição Standard Brasileira das Obras Psicológicas completas de Sigmund Freud. Rio de Janeiro: Imago, 1976. v. IV.

(1905). Três ensaios sobre a teoria da sexualidade. In: Edição Standard Brasileira das Obras Psicológicas completas de Sigmund Freud. Rio de Janeiro: Imago, 1976. v. VII, p. 129-250.

\footnotetext{
. (1911). Formulações sobre os dois princípios do funcionamento mental. In: Edição Standard Brasileira das Obras Psicológicas completas de Sigmund Freud. Rio de Janeiro: Imago, 1976. v. XII, p. 277-286

- (1915). Os instintos e suas vicissitudes. In: Edição Standard Brasileira das Obras Psicológicas completas de Sigmund Freud. Rio de Janeiro: Imago, 1976. v. XIV, p. 77-113.
} 
. (1917). Luto e melancolia. In: Edição Standard Brasileira das Obras Psicológicas completas de Sigmund Freud. Rio de Janeiro: Imago, 1976. v. XIV, p. 245-266.

. (1923). O ego e o id. In: Edição Standard Brasileira das Obras Psicológicas completas de Sigmund Freud. Rio de Janeiro: Imago, 1976. v. XIX, p. 73-148.

. (1924). A dissolução do complexo de Édipo. In: Edição Standard Brasileira das Obras Psicológicas completas de Sigmund Freud. Rio de Janeiro: Imago, 1976. v. XIX, p. 217-224.

- (1925) A negativa. In: Edição Standard Brasileira das Obras Psicológicas completas de Sigmund Freud. Rio de Janeiro: Imago, 1976. v. XIX, p.295-300.

. (1926) Inibições, sintomas e ansiedade. In: Edição Standard Brasileira das Obras Psicológicas completas de Sigmund Freud. Rio de Janeiro: Imago, 1976. v. XIX, p. 95-201.

- (1930) O mal-estar na civilização. In: Edição Standard Brasileira das Obras Psicológicas completas de Sigmund Freud. Rio de Janeiro: Imago, 1976. v. XXI, p.81 -171.

(1931) A sexualidade feminina. In: Edição Standard Brasileira das Obras Psicológicas completas de Sigmund Freud. Rio de Janeiro: Imago, 1976. v. XXI, p.259-279.

(1937) Construções em análise. In: Edição Standard Brasileira das Obras Psicológicas completas de Sigmund Freud. Rio de Janeiro: Imago, 1976. v. XXII, p.291-304.

GARCIA, C.A. Continuidade e ruptura no processo de constituição psíquica. Psicologia Clínica, 2009, 21.1., p. 73-89, Rio de Janeiro.

Brasília, 2012.

. O trauma em André Green. Alter, Vol. 30, n. 2, dezembro 2012. O estatuto do objeto em André Green. Conferência no Círculo Psicanalítico do Rio de Janeiro, 12 junho 2015. Rio de Janeiro.

GARCIA, C. e CARDOSO, M.R. Entre o eu e o outro. Espaços fronteiriços. Curitiba: Juruá Editora, 2010.

GOLSE, B. Insister-Exister. De l'être à la personne. Paris: PUF, 1990.

. Les origines de la pensée chez l'enfant. Psychiatrie Française, Paris, n. 1.93, março 1996.

. Du corps à la pensée. Paris: PUF, 1999. 
. De la différenciation à la séparation: It's a long way to go! Revue française de psychanalyse, 2/2001, vol. 65, p. 369-380. Paris, 2001.

GOLSE, B.; BYDLOWSKI, M. Da transparência psíquica à preocupação materna primária: uma via do objetalização. In: CORREA, Laurista (org.). Novos olhares sobre a gestação e a criança até os 3 anos. Brasília: L.G.E. Editora, 2002a.

Le bébé à l'épreuve des sens. In: ANDRE J. e BAUDIN M., La vie sensorielle. Paris, P.U.F. 2002b

GOLSE, B. e DESJARDINS, S. Corpo, forma, movimento e ritmo como precursores da emergência da intersubjetividade e da palavra no bebê. Revista Latino-americana de Psicopatologia Fundamental, vol. VIII, abril de 2005, p. $14-29.2005 b$.

L’être-bébé. Paris, Presses Universitaires de France, 2006.

L'inscription $d u$ soin piklérien/loczien dans les connaissances actuelles sur le développement de l'enfant. Conferência no Instituto Lòczy, Budapeste, 19 abril 2007.

GOLSE, B.; ROUSSILLON, R. La naissance de l'objet, Paris: PUF, 2010.

GREEN, A. L'analyste, la symbolisation et l'absence dans le cadre analytique. (1974) In: GREEN, La folie privé. Paris, Gallimard, 1990.

. Le langage dans la psychanalyse, in Langages ( $\mathrm{II}^{\mathrm{es}}$ Rencontres psychanalytiques d'Aix-en-Provence, 1983), Paris, Les Belles Lettres, coll. «Confluents psychanalytiques », 1984.

. Narcisismo de vida. Narcisismo de morte. São Paulo, Escuta, 1988.

. Le travail du négatif. Paris, Minuit, 1993.

- Le langage au sein de la théorie genérale de la représentation. In: Pulsions, Représentations, Langage, org. Piñol-Douriez, M., Lausanne, Delachaux et Niestlé, 1997.

L'originaire et la pensée des origines. In: Pulsions, Représentations, Langage, org. Piñol-Douriez, M. Lausanne, Delachaux et Niestlé, 1997.

. El pensamiento clínico. Buenos Aires: Amorrortu, 2007 (2002).

André Green: a clínica contemporânea e o enquadre interno do analista. Entrevista realizada por Fernando Urribari. Revista Brasileira de Psicanálise, Vol. 46, N 3, p. 215-225. São Paulo, 2012.

GUERRA, V. «O ritmo na vida psíquica: entre perda e reencontro". In: ARAGAO, R.O. \& ZORNIG, S.A. Nascimento: antes e depois - Cuidados em rede. Curitiba, Honoris Causa Editora, 2010. 
. Le rythme et la loi maternelle dans la subjectivation et la clinique infantile. Dialogues avec René Roussillon. Le Carnet Psy, Paris, 2014.

HAAG, G. La mère et le bébé dans les deux moitiés du corps. Neuropsychiatrie de l'enfance et de l'adolescence, 1985, 33, 2-3, p. 107-114. Paris, 1992.

- Hypothèse sur la structure rythmique du premier contenant. Gruppo, n ${ }^{0}$ 2, 1986, p. 45-53.

- De la sensorialité aux ébauches de pensée chez les enfants autistes. Revue internationale de psychopathologie, $\mathrm{n}^{\mathrm{o}} 3$, 1991, 51-63.

- Como o espírito vem ao corpo: ensinamentos da observação referentes aos primeiro desenvolvimentos e suas implicações na prevenção. In: LACROIX \& MONNMAIRANT, Observação de bebês: os laços de encantamento. Porto Alegre: Artes Médicas, 1997.

O teatro das mãos. Revista Brasileira da Sociedade Psicanalítica

de Porto Alegre, vol. X, n. 1, p. 9-27, Porto Alegre, abril 2003.

HOUZEL, D. L'aube de la vie psychique. Paris: ESF, 2002.

HOUZEL, D.; EMMANUELli, M.; MOGGIO, F. (orgs.). Dictionnaire de Psychopathologie de l'Enfant et de l'Adolescent. Paris: PUF, 2000.

JEAMMET, N. Faut-il être normal pour avoir des enfants normaux?. La Psychiatrie de l'Enfant, 1985, XXVIII, I, p. 221-258.

KONICHECKIS, A. Identité sensorielle chez le bébé et à l'adolescence. In: GUTTON, P. \& GODENNE, G. Troubles de la personnalité, troubles de la conduite. Monographie ISAP. Paris : GREUPP, p. 139-149, 2000.

Paris, P.U.F. Coll. Le fil rouge, 2008.

. Continuités, discontinuités... de la difficulté à établir des liens psychiques. In: CHABERT, C. (org.). In : Les séparations. Toulouse : Érès, 2013. p. 57-70.

Subjectivation et sensorialité : les embryons de sens. Conferência. III Encontro Internacional e X Encontro Nacional sobre o Bebê, PUC Rio, $1^{\circ} \mathrm{de}$ novembro de 2015. Rio de Janeiro, 2015.

LEBOVICI, S. Les interactions fantasmatiques. Revue de Médecine Psychosomatique, nº 37/38, p. 39-50, 1994.

LECANUET, J.P. et al. Le foetus dans son environment. In: La grossesse, l'enfant virtual et la parentalité. MISSONIER, S. (org.), Paris: PUF, 2004.

MAIELLO, S. L'objet sonore. Hypothèse d'une mémoire auditive prénatale. Journal de la psychanalyse de l'enfant, 1991, 20, 40-66. Paris. 
- Trames sonores et rythmiques primordiales. Journal de psychanalyse de l'enfant, $n^{\circ} 26$, Paris, 2000.

MARCELLI, D. Le rôle des microrythmes et des macrorythmes dans l'émergence de la pensée chez le nourrisson. In: La psychiatrie de l'enfant. Vol. XXXV, Fasc. 1, p.57-82. Paris, 1992.

. La surprise, chatouille de l'âme. Ed. Albin Michel, Paris, 2000/2006

. Entre les microrythmes et les macrorythmes: la surprise dans l'interaction mère-bébé. Spirale, 4/2007 (n 44), p. 123-129. Paris, 2007.

MARTY, P. L'ordre psychosomatique. Les mouvements individuels de vie et de mort, Paris, Payot, 1998.

- La relation objectale allergique. Revue Française de Psychanalyse, XII (1), p. 5-35. Paris, 1958.

MILNER, M. Le rôle de l'illusion dans la formation du symbole. Revue Française de Psychanalyse, 5-6, p. 844-874, Paris. 1977

Les concepts psychanalytiques sur les deux fonctions du symbole. Journal de la psychanalyse de l'enfant, 1990, 8 ("Rêves, jeux, dessins"), 244278.

MISSONIER, S. Transparence psychique de la grossesse. In: SOULÉ, M. et al. Écoute voir... l'échographie de la grossesse.Toulouse, Érès, 1999.

Érès, 2003.

La consultation thérapeutique périnatale. Ramonville Saint-Agne:

L'enfant du dedans et la relation d'objet virtuel. In: MISSONIER, S.; GOLSE, B.; SOULÉ, M. (orgs.). La grossesse, l'enfant virtuel et la parentalité. Paris: PUF, 2004.

foetale. La psychiatrie de l'enfant, Paris, L, 1, 61-80, 2007.

PUF, 2009.

PALACIO-ESPASA, F. \& MANZANO, J. Scenários narcissiques de la parentalité. Paris: PUF, 1999.

PEDINIELLI, J.L. Verbete Pictogramme. In: HOUZEL, D.; EMMANUELLI, M.; MOGGIO, F. (orgs.). Dictionnaire de Psychopathologie de l'Enfant et de l'Adolescent. Paris: PUF, 2000.

PIÑOL-DOURIEZ, M. Bébé agi. Bébé actif. (L'émergence du symbole dans l'économie interactionnelle). Paris: PUF, 1984. 
Niestlé, 1997

PRAT, R. ; COSSART, M, GARIEL-BATAILLE, S. "La précarité psychique". In: La méthode d'observation des bébés selon Esther Bick, sous la dir. Pierre Delion, Ramoinville Saint-Agne, Ed. Érès, Coll. La vie de l'enfant, 2008.

PRAT, R. La préhistoire de la vie psychique: son devenir et ses traces dans l'opéra de la rencontre et le processus thérapeutique. Revue française de psychanalyse, 1/2007, vol. 71, p. 97-114. Paris

QUINODOZ, J.-M.: La solitude apprivoisée. L'angoisse de séparation en psychanalyse, Paris: Presses Universitaires de France, 1991.

RACAMIER, P.C. et al. La mère et l'enfant dans les psychoses du post-partum. L'évolution psychiatrique, vol. 26, nº4, p. 525-570, Paris, 1961.

RESNIK, S. Espace mental. Toulouse: Érès, 1994.

ROUSSILLON, R. http://bsf.spp.asso.fr/Auteur.htm?numrec=061934580911630. La métapsychologie des processus et la transitionnalité. Revue Française de

Psychanalyse, 1995, vol. 59, $\mathrm{n}^{\circ}$ spécial, pp. 1375-1519.

Agonie, clivage et symbolisation. Paris: PUF, 1999.

Paradoxos e situações limite da psicanálise, São Leopoldo, Ed. Unisinos, 2006.

Le Moi-peau et la réflexivité. In: Didier Anzieu: le Moi-peau et la psychanalyse des limites. CHABERT, C.; CUPA, D.; KAES, R.; ROUSSILLON, R. (orgs.) Toulouse: Érès, 2007.

. Le transitionnel, le sexuel et la réflexivité, Paris, Dunod, 2008.

Formes complexes de la survivance de l'objet. Conferência. Hospital Necker, 18 setembro 2010, Paris: Site Psynem Necker

ROUSSILLON, R. \& GOLSE, B. La naissance de l'objet. Paris, PUF, 2010.

Manuel de la pratique clinique em psychologie et psychopathologie. Issy-les-Moulineaux: Elsevier-Masson, 2012a.

Experiências traumáticas primárias. Conferência. Sociedade Brasileira de Psicanálise do Rio de Janeiro, maio 2012. Rio de Janeiro. 2012b.

La séparation et la dialectique présencelabsence. Les séparations, Toulouse : Érès, 2013. p.213-230.

ROUSSILLON, R. \& BRUN, A. Formes primaires de symbolisation. Paris, Dunod, 2014. 
SIROL, F. On bat un foetus! Existe-t-il des grossesses maltraitantes?. In: La grossesse, l'enfant virtuel et la parentalité, org. S. Missonier, B. Golse, M. Soulé, PUF, Paris, 2004.

SOULÉ, M. Introduction à la psychiatrie foetale. Paris: ESF, 1992

SOULÉ, M. \& SOUBIEUX, M.J. La psychiatrie foetale. La grossesse, l'enfant virtuel et la parentalité, Paris, PUF., 2004, p. 295-334.

STERN, D. Le mode interpersonnel du nourrisson: une perspective psychanalytique e développementale. Paris: PUF, 1989.

l'enfant, 1993, 14, 13-15. Paris.

\section{Journal de la psychanalyse de} La constellation maternelle. Paris: Calman-Lévy, 1997.

. Verbete Accordage affectif. In: HOUZEL, D.; EMMANUELLI, M.; MOGGIO, F. (orgs.). Dictionnaire de Psychopathologie de l'Enfant et de l'Adolescent. Paris: PUF, 2000.

Le moment présent en psychothérapie: un monde dans un grain de sable. Paris, Odile Jacob, 2003.

Journal d'un bébé. Paris: Odile Jacob, 1992/2004.

STOLERU, S.; MORALES-HUET, M. Processus de recherché et processus psychothérapique. Neuropsychiatrie de l'enfant et de l'adolescent, 43, p. 164$170,1989$.

STOLERU, S. De l'arrêt de la contraception aux premiers mois postnatales. Les premières étapes de la parentalité adulte. In: Psychiatrie périnatale, Mazet, P., Lebovici, S., Paris, PUF, 1998.

TREVARTHEN, C. \& AITKEN, K.J. Intersubjectivité chez le nourrisson: recherche, théorie et application clinique. Devenir, 15, 4, 2003.

TUSTIN, F. Les états autistiques chez l'enfant. Paris: Seuil, 1986.

URRIBARI, F. Passion clinique, pensée complexe. Postface. In: GREEN, A. Illusions et désillusions du travail psychanalytique. Paris, Odile Jacob, 2010.

WINNICOTT, D. (1947). La haine dans le contretransfert. De la pédiatrie à la psychanalyse, Paris: Payot, 1969. p. 48-58.

(1949). L'esprit et ses rapports avec le psyché-soma. De la pédiatrie à la psychanalyse, Paris: Payot, 1969. p. 66-79.

(1950-1955). L'agressivité et ses rapports avec le développement affectif. De la pédiatrie à la psychanalyse, Paris: Payot, 1969. p. 80-97. 
. (1951). Objets transitionnels et phénomènes transitionnels. De la pédiatrie à la psychanalyse, Paris: Payot, 1969. p. 109-125.

(1956). La préoccupation maternelle primaire. De la pédiatrie à la psychanalyse, Paris: Payot, 1969. p. 168-174.

. (1958). La capacité d'être seul. De la pédiatrie à la psychanalyse, Paris: Payot, 1969. p. 205-213.

. (1960). La théorie de la rélation parent-nourrisson. De la pédiatrie à la psychanalyse, Paris: Payot, 1969. p. 237-256.

- (1967). Le rôle de miroir de la mère et de la famille dans le développement de l'enfant. Jeu et réalité - L'espace potentiel, Paris: Gallimard, 1975. p. 153-162.

—. De la pédiatrie à la psychanalyse. Paris: Payot, 1969.

O Brincar e a Realidade. Rio de Janeiro, Imago, 1975.

WISNIK, J. M. O som e o sentido. Companhia das Letras, São Paulo, 2004.

WOLFF-QUENOT, M.J. Utero: mythes, croyances et cultures, Paris, Masson, 2001 .

ZORNIG, S.M.A-J. Clínica dos primórdios e processos de simbolização primários. Psicol. clin., [online]. 2015, vol. 27, n. 2, p. 121-136. Rio de Janeiro, 2015.

ZORNIG, S.A. e ARAGÃO, R.O. Clínica da relação pais/bebê: novos paradigmas para a psicanálise. Pulsional Revista de Psicanálise, Ano 22, N. 4, Dezembro de 2009. São Paulo, Ed. Escuta. 